\title{
Rapid global phaseout of animal agriculture has the potential to stabilize greenhouse gas levels for 30 years and offset 68 percent of $\mathrm{CO}_{2}$ emissions
}

\author{
Michael B. Eisen ${ }^{1^{*}}$ and Patrick O. Brown ${ }^{2,3^{*}}$ \\ ${ }^{1}$ Department of Molecular and Cell Biology, Howard Hughes Medical Institute, University of California, \\ Berkeley, CA 94720. ${ }^{2}$ Department of Biochemistry (Emeritus), Stanford University School of Medicine, \\ Stanford, CA 94305. ${ }^{3}$ Impossible Foods, Redwood City, CA 94063.
}

* Address correspondence to:

mbeisen@berkeley.edu and pat.brown@impossiblefoods.com.

Keywords: Animal Agriculture, Livestock, Greenhouse Gases, Climate Change 


\section{$\underline{\text { Abstract }}$}

Animal agriculture contributes significantly to global warming through ongoing emissions of the potent greenhouse gases methane and nitrous oxide, and displacement of biomass carbon on the land used to support livestock. However, because estimates of the magnitude of the effect of ending animal agriculture often focus only on one factor, the full potential benefit of a more radical change remains underappreciated. Here we quantify the full "climate opportunity cost" of current global livestock production, by modeling the combined, long-term effects of emission reductions and biomass recovery that would be unlocked by a phase out of animal agriculture. We show that, even in the absence of any other emission reductions, persistent drops in atmospheric methane and nitrous oxide levels, and slower carbon dioxide accumulation, following a phase out of livestock production would, through the end of the century, have the same cumulative effect on the warming potential of the atmosphere as a 25 gigaton per year reduction in anthropogenic $\mathrm{CO}_{2}$ emissions, providing half of the net emission reductions necessary to limit warming to $2^{\circ} \mathrm{C}$. The magnitude and rapidity of these potential effects should place the reduction or elimination of animal agriculture at the forefront of strategies for averting disastrous climate change. 


\section{Significance Statement}

The use of animals to produce food has a negative impact on the climate, but the benefits of a global switch to a plant based diet are underappreciated. We show that the global warming impact, through the rest of this century, of eliminating greenhouse gas emissions from livestock and allowing native ecosystems to regrow on the land currently used to house and feed livestock, would be equivalent to a $68 \%$ reduction in carbon dioxide emissions. We hope putting clearer numbers on the "climate opportunity cost" of our continued use of animals as food technology will help policymakers and the public properly prioritize dietary change as a climate defense strategy. 
bioRxiv preprint doi: https://doi.org/10.1101/2021.04.15.440019; this version posted October 12,2021 . The copyright holder for this preprint

(which was not certified by peer review) is the author/funder, who has granted bioRxiv a license to display the preprint in perpetuity. It is made available under aCC-BY 4.0 International license.

\section{Declaration of Conflict of Interest}

Patrick Brown is the founder and CEO of Impossible Foods, a company developing alternatives to animals in food-production. Michael Eisen is an advisor to Impossible Foods. Both are shareholders in the company and thus stand to benefit financially from reduction of animal agriculture. 


\section{Introduction}

The use of animals as a food-production technology has well-recognized negative impacts on our climate. The historical reduction in terrestrial biomass as native ecosystems were transformed to support grazing livestock and the cultivation of feed and forage crops accounts for as much as a third of all anthropogenic $\mathrm{CO}_{2}$ emissions to date (Friedlingstein et al., 2020; Hayek et al., 2021; Strassburg et al., 2020). Livestock, especially large ruminants, and their supply chains, also contribute significantly to anthropogenic emissions of the potent greenhouse gases (GHGs) methane and nitrous oxide (Gerber et al., 2013; MacLeod et al., 2018; Steinfeld et al., 2006).

Solving the climate crisis requires massive cuts to GHG emissions from transportation and energy production. But even in the context of large-scale reduction in emissions from other sources, major cuts in food-linked emissions are likely necessary by 2075 to limit global warming to $1.5^{\circ} \mathrm{C}$ (Clark et al., 2020). While a reduction of food-linked emissions can likely be achieved by increasing agricultural efficiency, reducing food waste, limiting excess consumption, increasing yields, and reducing the emission intensity of livestock production (Cusack et al., 2021; Hristov et al., 2013a, 2013b; Montes et al., 2013; Poore and Nemecek, 2018; Springmann et al., 2018a), they are not anticipated to have the same impact as a global transition to a plant-rich diet (Clark et al., 2020; Gerber et al., 2013).

Nutritionally balanced plant-dominated diets are common, healthy and diverse (Agnoli et al., 2017; American Dietetic Association and Dietitians of Canada, 2003; Craig et al., 2009; Tilman and Clark, 2014; Willett et al., 2019), but are rarely considered in comprehensive strategies to mitigate climate change (IPCC, 2018), and there is controversy about their viability and the magnitude of their climate benefit (Liu et al., 2021). One source of this discordance is that widely cited estimates of livestock contributions to global warming (Gerber et al., 2013; Steinfeld 
et al., 2006; Twine, 2021) account only for ongoing emissions , and not for the substantial and reversible warming impact of historical land use change (Hayek et al., 2021; Strassburg et al., 2020).

The most recent published estimates are that ongoing emissions from animal agriculture represent around $8.0 \mathrm{Gt} \mathrm{CO}_{2}$ eq per year, $16.5 \%$ of annual anthropogenic greenhouse gas emissions (Twine, 2021), and recent estimates (Hayek et al., 2021; Strassburg et al., 2020) suggest that on the order of $800 \mathrm{Gt} \mathrm{CO}_{2}$ equivalent carbon could be fixed via photosynthesis if native biomass were allowed to recover on the $30 \%$ of Earth's land surface current devoted to livestock production. Thus, crudely, eliminating animal agriculture has the potential to reduce net emissions by the equivalent of $1,400 \mathrm{Gt} \mathrm{CO}_{2}$ this century. To put this number in perspective, total anthropogenic $\mathrm{CO}_{2}$ emissions since industrialization are estimated to be around 1,650 Gt (Friedlingstein et al., 2020).

However, a substantial fraction of the emissions impact of animal agriculture comes from methane $\left(\mathrm{CH}_{4}\right)$ and nitrous oxide $\left(\mathrm{N}_{2} \mathrm{O}\right)$, which, unlike $\mathrm{CO}_{2}$, decay in the atmosphere on relevant timescales, and recent studies have highlighted the need to consider these atmospheric dynamics when assessing their impact (Allen et al., 2018, 2016; Cain et al., 2019). Of critical importance, many of the beneficial effects on greenhouse gas levels of eliminating livestock would accrue rapidly, via biomass recovery and decay of short-lived atmospheric $\mathrm{CH}_{4}$, and therefore their cooling influence would be felt for an extended period of time, having a greater cumulative effect on warming.

Our goal here was to accurately quantify the full impact of current animal agriculture on the climate, taking into account the currently unrealized opportunities for emission reduction and biomass recovery together, and explicitly considering the impact of their kinetics on warming. Our approach differs from other recent studies (Springmann et al., 2018b; Xu et al., 2021) in that 
we did not attempt to predict how global food production and consumption might change with growing populations, economic development, advances in agriculture, climate change and other socioeconomic factors. Nor do we tackle the social, economic, nutrition and agricultural challenges inherent to such a large change in global production.

We used publicly available, systematic data on livestock production in 2019 (FAO, 2021), livestock-linked emissions (FAO, 2021; MacLeod et al., 2018), and biomass recovery potential on land currently used to support livestock (Hayek et al., 2021; Strassburg et al., 2020) to predict how the phaseout of all or parts of global animal agriculture production would alter 2019 net anthropogenic emissions. We then used a simple climate model to project how these changes would impact the evolution of atmospheric GHG levels and warming for the rest of the century.

We calculated the combined impact of reduced emissions and biomass recovery by comparing the cumulative reduction, relative to current emission levels, of the global warming potential of GHGs in the atmosphere for the remainder of the 21st century under different livestock replacement scenarios to those that would be achieved by constant annual reductions in $\mathrm{CO}_{2}$ emissions.

\section{Results}

\section{Modeling the effect of eliminating animal agriculture on GHG levels}

We implemented a simple climate model that projects atmospheric GHG levels from 2020 to 2100 based on a time series of annual emissions of $\mathrm{CO}_{2}, \mathrm{CH}_{4}$ and $\mathrm{N}_{2} \mathrm{O}$ and a limited set of parameters. We then compared various hypothetical dietary perturbations to a "business as usual" (BAU) reference in which emissions remain fixed at 2019 levels, based on global emissions data from FAOSTAT (FAO, 2021). 
The dietary scenarios include the immediate replacement of all animal agriculture with a plant-only diet (IMM-POD), a more realistic gradual transition, over a period of 15 years, to a plant-only diet (PHASE-POD), and versions of each where only specific animal products were replaced.

We updated estimates of global emissions from animal agriculture by scaling country-, speciesand product-specific emission intensities from the Global Livestock Environmental Assessment Model (MacLeod et al., 2018), with country-specific data on primary production of livestock products from the Food and Agriculture Organization (FAO) database FAOSTAT (FAO, 2021).

Based on this analysis, in 2019 (the most recent year for which full data are available), global production of animal-derived foods led to direct emissions of $1.6 \mathrm{Gt} \mathrm{CO}_{2}$, due primarily to energy use (as our model assumes constant overall rates of consumption, we excluded emissions due to land clearing, which are associated with agricultural expansion), $120 \mathrm{Mt} \mathrm{CH}_{4}$ due primarily to enteric fermentation and manure management, and 7.0 $\mathrm{Mt} \mathrm{N}_{2} \mathrm{O}$ due primarily to fertilization of feed crops and manure management (Figure 1 and Figure 1-S1).

These numbers are broadly consistent with other recent estimates (Gerber et al., 2013; Steinfeld et al., 2006; Xu et al., 2021), and correspond, respectively, to $4 \%$ of $\mathrm{CO}_{2}, 35 \%$ of $\mathrm{CH}_{4}$ and $66 \%$ of $\mathrm{N}_{2} \mathrm{O}$ emissions from all human activities, using total human emissions data from FAOSTAT (FAO, 2021). Combining the effects of the three gases, using global warming potentials from (Intergovernmental Panel on Climate Change, 2014), results in $6.3 \mathrm{Gt} \mathrm{CO}_{2} \mathrm{eq}$, with the major difference from the $8.0 \mathrm{Gt} \mathrm{CO}_{2}$ eq number cited above coming from our not including emissions from ongoing land use change.

We modeled the recovery of biomass on land currently used in livestock production using data from (Hayek et al., 2021) who estimate that the return of land currently used in livestock production to its native state would sequester, over 30 years, $215.5 \mathrm{Gt}$ of carbon (equivalent to 
A

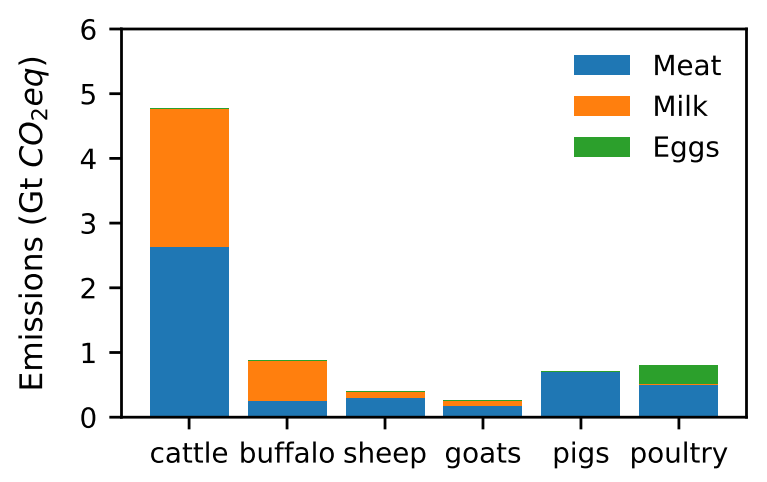

B

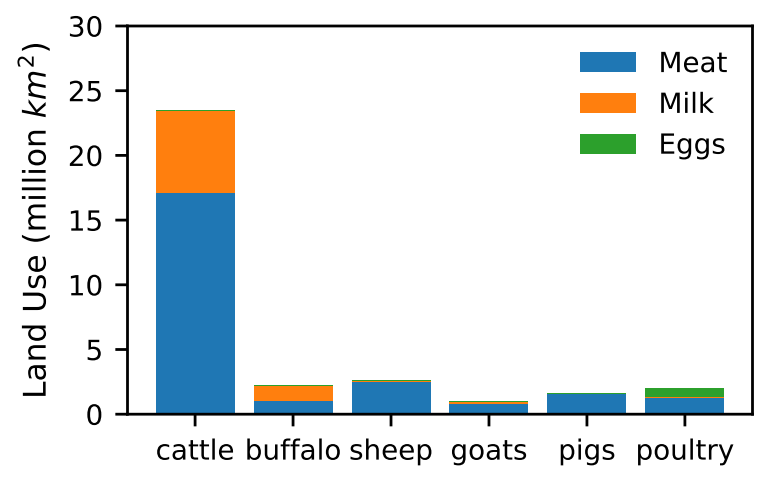

Figure 1. Global emissions and land use footprints of animal agriculture.

Total $\mathrm{CO}_{2}$ equivalent emissions (A) assembled from species, product and country-specific production data from FAOSTAT for 2019 and species, product, region and greenhouse-gas specific emissions data from GLEAM (MacLeod et al., 2018), using $\mathrm{CO}_{2}$ equivalents of 34 for $\mathrm{CH}_{4}$ and 298 for $\mathrm{N}_{2} \mathrm{O}$. Land use (B) assembled from species, product and country-specific production data from FAOSTAT for 2019 and species and product specific land use data from (Poore and Nemecek, 2018). 
$790 \mathrm{Gt}$ of $\mathrm{CO}_{2}$ ) in plant and non-living biomass. A similar estimate was obtained by (Strassburg et al., 2020).

We assumed in all these hypothetical scenarios that non-agricultural emissions would remain constant; that food from livestock is replaced by a diverse plant-based diet; and that, when land is removed from livestock production, the conversion of atmospheric $\mathrm{CO}_{2}$ into terrestrial biomass occurs linearly over the subsequent thirty years. (We consider alternative assumptions in the "Sensitivity Analysis" section below).

We emphasize that we are not predicting what will happen to global diets. Rather we are projecting simplified scenarios of dietary change forward through time to characterize and quantify the climate impact of current animal agriculture production. Our climate model is intentionally simple, considering only the partition of terrestrial emissions into the atmosphere, and the decay of methane and nitrous oxide, although it replicates the qualitative behavior of widely used MAGICC6 (Meinshausen et al., 2011).

Figure 2 shows annual emissions and projected atmospheric levels of $\mathrm{CO}_{2}, \mathrm{CH}_{4}$ and $\mathrm{N}_{2} \mathrm{O}$ under BAU and PHASE-POD through the end of the century (projections for IMM-POD and additional scenarios are shown in the supplemental versions of Figure 2).

\section{$\underline{\text { Rapid phaseout of animal agriculture would freeze increases in the warming potential of }}$}

\section{the atmosphere for 30 years}

The impact of PHASE-POD on $\mathrm{CO}_{2}$ emissions would be greatest in the period between 2030 and 2060, when biomass recovery on land previously occupied by livestock or feed crops reaches its peak, slowing the rise of atmospheric $\mathrm{CO}_{2}$ levels during this interval.

Atmospheric $\mathrm{CH}_{4}$ and $\mathrm{N}_{2} \mathrm{O}$ levels continue to increase in both BAU and PHASE-POD during the transition period, but begin to drop in PHASE-POD as the abatement of animal 
A

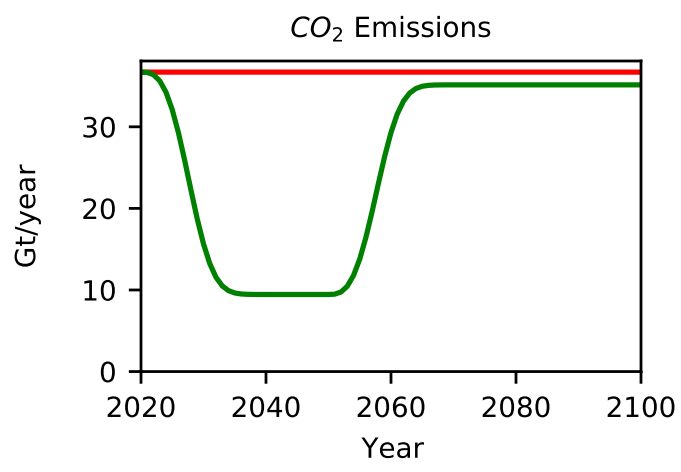

$\mathrm{CH}_{4}$ Emissions

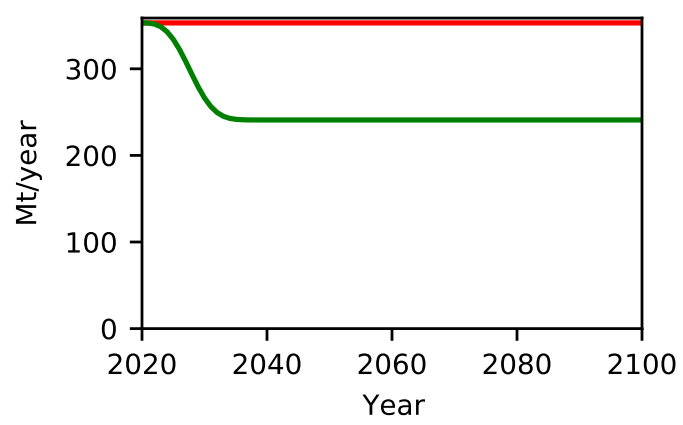

$\mathrm{N}_{2} \mathrm{O}$ Emissions

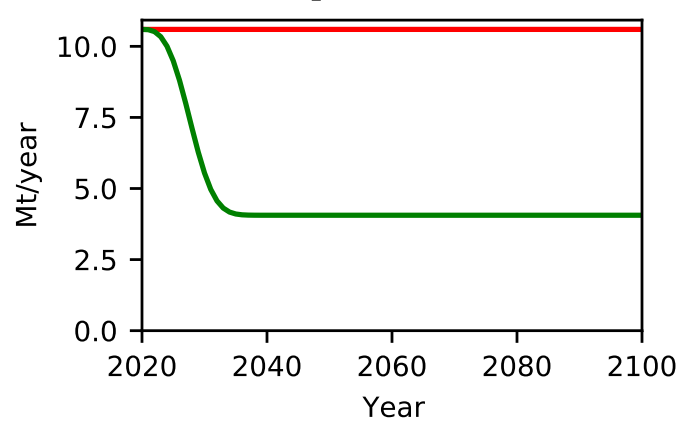

B
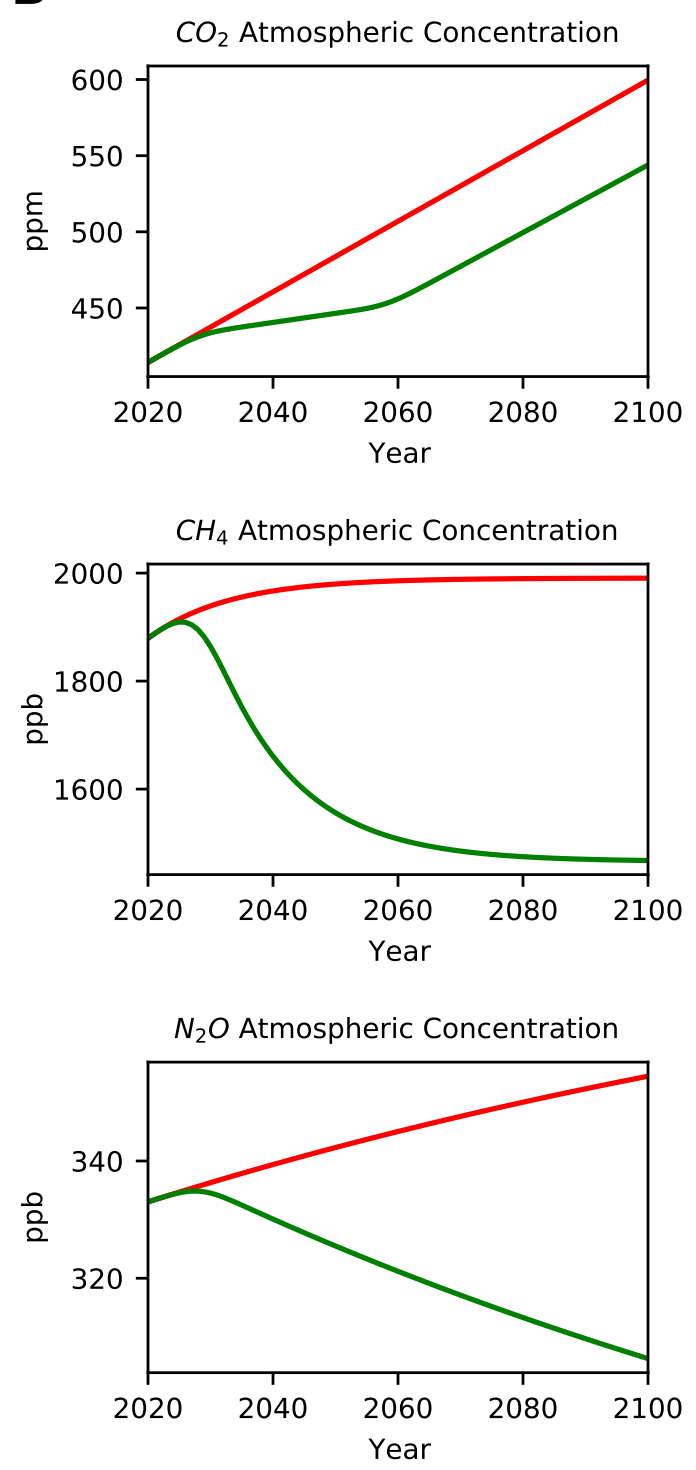

Figure 2. Impact of 15 year phaseout of animal agriculture on atmospheric greenhouse gas levels.

(A) Projected annual emissions of $\mathrm{CO}_{2}, \mathrm{CH}_{4}$ and $\mathrm{N}_{2} \mathrm{O}$ for Business as Usual (red) and PHASEPOD (green) assuming a 15 year transition to new diet and 30 year carbon recovery. (B) Projected atmospheric concentrations of $\mathrm{CO}_{2}, \mathrm{CH}_{4}$ and $\mathrm{N}_{2} \mathrm{O}$ under each emission scenario. 
agriculture-linked emissions accelerates. $\mathrm{CH}_{4}$, with a half-life in the atmosphere of around 9 years, approaches a new and lower steady-state level towards the end of the century, while $\mathrm{N}_{2} \mathrm{O}$, with a half-life of around 115 years, does so over a longer time-scale.

To capture the combined global warming impact of the changing levels of these GHGs, we calculated radiative forcing (RF), the reduction in radiative cooling by GHG absorption of infrared radiation, using the formulae described in (Myhre et al., 1998; Shine, 2000) and used in MAGICC6 (Meinshausen et al., 2011).

Figure 3 shows that with PHASE-POD there would effectively be no net increase in RF between 2030 and 2060. And even after that 30-year pause in the previously monotonically increasing global warming potential of the atmosphere, the difference in RF between the POD and BAU scenarios would continue to increase, due to the absence of direct emissions from animal agriculture and the continuing decay of previously emitted $\mathrm{CH}_{4}$ and $\mathrm{N}_{2} \mathrm{O}$ towards lower steady-state values.

\section{Rapid phaseout of animal agriculture could achieve half of the emission reductions}

\section{needed to meet Paris Agreement GHG targets}

By the end of the century the RF under PHASE-POD would be $3.8 \mathrm{Wm}^{-2}$ compared to $4.9 \mathrm{Wm}^{-2}$ for $\mathrm{BAU}$, a reduction in RF equivalent to what would be achieved by eliminating $1,680 \mathrm{Gt}$ of $\mathrm{CO}_{2}$ emissions (Figure 4-S1), or 46 years of global anthropogenic $\mathrm{CO}_{2}$ emissions at the current rate of $36 \mathrm{Gt} /$ year.

In 2010, the climate modeling community defined a series of four "Representative Concentration Pathways" that capture a wide range of future warming scenarios, leading to 2100 RF levels of $8.5,6.0,4.5$ and $2.6 \mathrm{Wm}^{-2}$ (which is approximately the RF of current atmospheric greenhouse gas levels), respectively (Moss et al., 2010; van Vuuren et al., 2011). These model pathways 


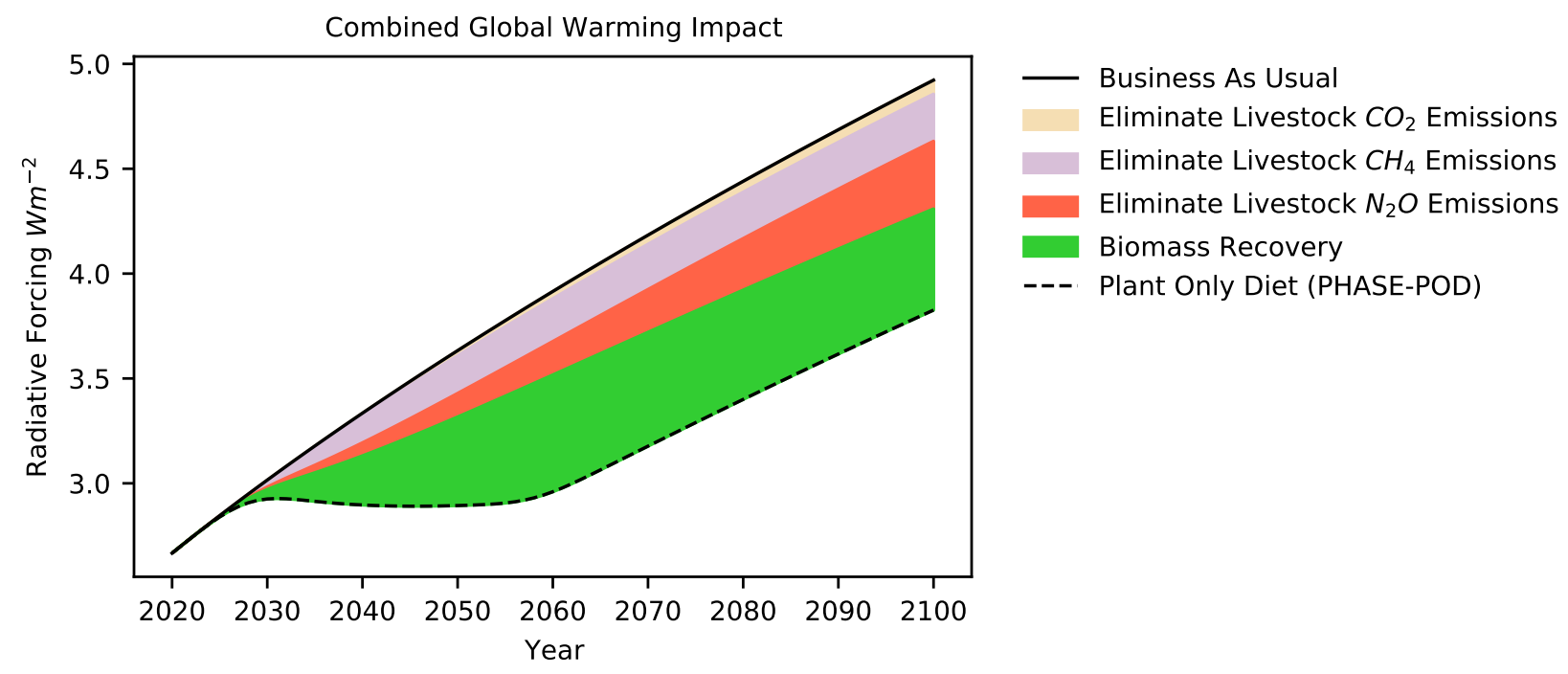

Figure 3. Phaseout of animal agriculture reduces global warming impact of atmosphere.

Effect of eliminating emissions linked to animal agriculture and of biomass recovery on land currently used in animal agriculture on Radiative Forcing (RF), a measure of the instantaneous warming potential of the atmosphere. RF values computed from atmospheric concentrations in by formula of (Myhre et al., 1998; Ramaswamy et al., 2001) as modified in MAGICC6 (Meinshausen et al., 2011) with adjustment for gasses other than $\mathrm{CO}_{2}, \mathrm{CH}_{4}$ and $\mathrm{N}_{2} \mathrm{O}$ as described in text. 
were extended after the Paris Agreement to include a target of $1.9 \mathrm{Wm}^{-2}$. Although the exact relationship between RF and global warming is incompletely understood, 2100 RF values of 1.9 and $2.6 \mathrm{Wm}^{-2}$ are generally used as targets for limiting warming in this century to $1.5^{\circ} \mathrm{C}$ and $2.0^{\circ} \mathrm{C}$, respectively, over the baseline pre-industrial global average temperature (IPCC, 2018).

Reducing 2100 RF from 4.9 $\mathrm{Wm}^{-2}$ under BAU to $2.6 \mathrm{Wm}^{-2}$ would require a reduction of atmospheric $\mathrm{CO}_{2}$ levels by 204 ppm, equivalent to $3,230 \mathrm{Gt}$ of $\mathrm{CO}_{2}$ emissions (Figure 4 and Figure 4-S1), and an additional $47 \mathrm{ppm}$ reduction, equivalent to $750 \mathrm{Gt}$ of $\mathrm{CO}_{2}$ emissions, would be required to reach $1.9 \mathrm{Wm}^{-2}$.

Thus the $1,680 \mathrm{Gt}$ of $\mathrm{CO}_{2}$ equivalent emissions reductions from the phased elimination of animal agriculture, would, without any other intervention to reduce GHG emissions, achieve $52 \%$ of the net GHG emissions reductions necessary to reach the $2100 \mathrm{RF}$ target of $2.6 \mathrm{Wm}^{-2}$ and $42 \%$ of the emissions reductions necessary to reach the $1.9 \mathrm{Wm}^{-2}$ target (IPCC, 2018).

\section{Eliminating animal agriculture has the potential to offset 65 percent of current} anthropogenic $\mathrm{CO}_{2}$ emissions

While widely used, such single point estimates of radiative forcing tell an incomplete story, as temperature change, and other climate impacts, depend cumulatively on the temporal trajectories of changing atmospheric greenhouse gas levels.

To capture such dynamic effects, we computed, for each dietary scenario, the integral with respect to time of the RF difference between the scenario and BAU, from 2021 (the start of the intervention in this model) to a given year " $y$ ". We designate this cumulative RF difference for year $y$, CRFD $^{y}$. We then determined, for each dietary scenario and year $y$, what level of reduction in annual $\mathrm{CO}_{2}$ emissions alone, relative to $\mathrm{BAU}$, would yield the same CRFD , and 


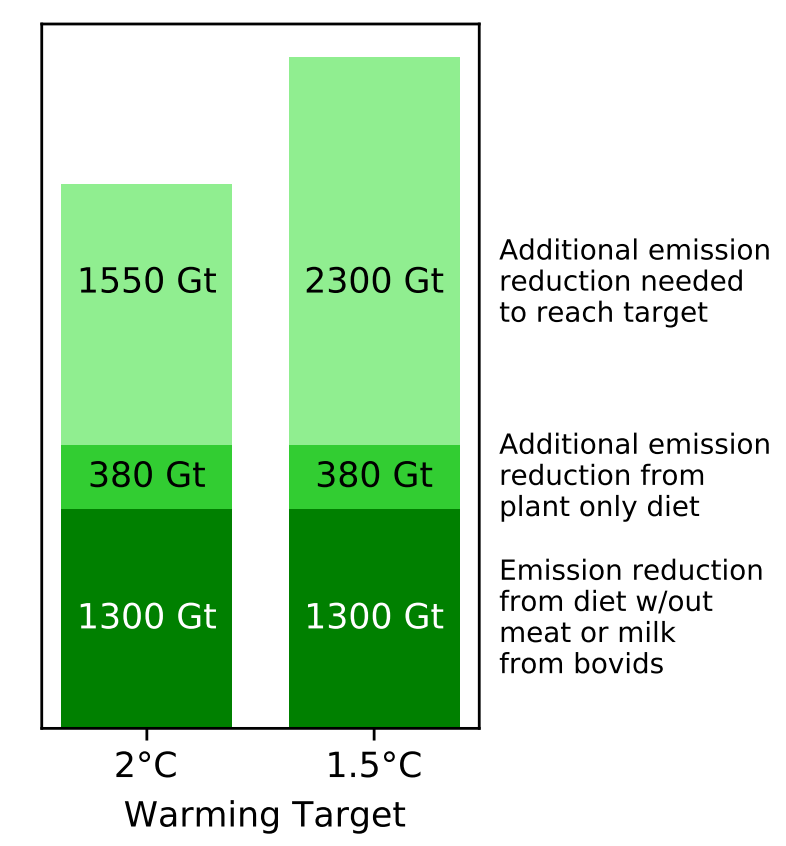

Figure 4. Impact of dietary transitions in curtailing global warming.

Using projected $\mathrm{CH}_{4}$ and $\mathrm{N}_{2} \mathrm{O}$ levels in 2100 under business as usual diet as a baseline for RF calculation, we computed the $\mathrm{CO}_{2}$ reductions necessary to reduce RF from the business as usual diet level of $\mathrm{RF}=1.31$ to the bovid-free diet level of $\mathrm{RF}=4.09\left(1300 \mathrm{Gt}^{\mathrm{C}} \mathrm{O}_{2}\right)$, the plant-only diet level of $\mathrm{RF}=3.83\left(1680 \mathrm{Gt} \mathrm{CO}_{2}\right)$, the $2.0^{\circ} \mathrm{C}$ global warming target of $\mathrm{RF}=2.6\left(3230 \mathrm{Gt}^{\mathrm{CO}} \mathrm{O}_{2}\right)$ and the $1.5^{\circ} \mathrm{C}$ global warming target of $\mathrm{RF}=1.9\left(3980 \mathrm{Gt} \mathrm{CO}_{2}\right)$. For this analysis we used a corrected $\mathrm{RF}$ that accounts for the absence of other gases in our calculation by training a linear regression model on published MAGICC6 output to estimate from $\mathrm{CO}_{2}, \mathrm{CH}_{4}$ and $\mathrm{N}_{2} \mathrm{O}$ levels the residual $\mathrm{RF}$ impact of other gases. 
designate this annual $\mathrm{CO}_{2}$ equivalent $\mathrm{aCO}_{2} \mathrm{eq}^{\mathrm{y}}$ (see Figures 5-S1 to 5-S4 for details of these equivalences).

Critical features of $\mathrm{aCO}_{2} \mathrm{eq}$ are that it operates directly on $\mathrm{RF}$ inferred from combined trajectories of atmospheric levels of all GHGs, and thus can directly capture the effects of arbitrarily complex interventions, and that it equates the cumulative RF impact of an intervention over a specified time window to a single number: the sustained reductions in $\mathrm{CO}_{2}$ emissions that would have the same cumulative impact.

aCO${ }_{2}$ eq is closely related to, and motivated by similar goals as, $\mathrm{CO}_{2}$-forcing-equivalent $\left(\mathrm{CO}_{2}\right.$-fe $)$ emissions (Jenkins et al., 2018), which equates an arbitrary emission trajectory of all GHGs to a trajectory of $\mathrm{CO}_{2}$ emissions that would produce the same trajectory of RF, and GWP* (Allen et al., 2018, 2016; Cain et al., 2019), which uses various formulae to equate changes in GHG emissions to instantaneous $\mathrm{CO}_{2}$ pulses.

Figure 5 shows the $\mathrm{aCO}_{2}$ eq for different scenarios for reference years 2050 (to capture short term impacts) and 2100 (Figure 5-S3 shows the full dependence of $\mathrm{aCO}_{2}$ eq on the reference year). The $\mathrm{aCO}_{2} \mathrm{eq}^{2100}$ for PHASE-POD is $-24.8 \mathrm{Gt} /$ year. As global anthropogenic $\mathrm{CO}_{2}$ emissions are currently approximately $36 \mathrm{Gt} /$ year, that PHASE-POD would have the same effect, through the end of the century, as a $68 \%$ reduction of $\mathrm{CO}_{2}$ emissions.

This effect on warming through this century is of similar magnitude to that achieved by eliminating all global $\mathrm{CO}_{2}$ emissions by 2050 , as envisioned under the Paris Climate Agreement (Figure 2-S13 and Figure 3-S2), which has an $\mathrm{aCO}_{2} \mathrm{eq}^{2100}$ of $-20.9 \mathrm{Gt} /$ year. 


\section{Replacing ruminants achieves over 90 percent of climate benefit of eliminating animal}

\section{$\underline{\text { agriculture }}$}

We next computed $\mathrm{aCO}_{2} \mathrm{eq}^{2100}$ for the 15 year phaseout of individual animal products and product categories (Figure 5 and 6A; Table 1), using the species- and product-specific emissions and land use values described above. Beef alone accounts for $47 \%$ of the benefits of phasing out all animal agriculture, and cow milk $24 \%$. Meat and milk from bovids (cattle and buffalo) account for $79 \%$ of the climate opportunity. Although they provide less than $19 \%$ of the protein in the human diet (FAO, 2021), ruminants (cattle, buffalo, sheep and goats) collectively account for $90 \%$ of the $\mathrm{aCO}_{2} \mathrm{eq}^{2100}$ of all livestock.

These product-specific $\mathrm{aCO}_{2}$ eq's can be interpreted on a per product unit (Figure $6 \mathrm{~B}$ ) or per protein unit (Figure 6C) as emissions intensities. Eliminating the consumption of a kilogram of beef, for example, is equivalent to an emissions reduction of $297 \mathrm{~kg} \mathrm{CO}_{2} .38$ percent $(113 \mathrm{~kg}$ $\mathrm{aCO}_{2} \mathrm{eq}$ ) comes from reduced emission, in line with the mean estimate of $99.5 \mathrm{~kg} \mathrm{CO}_{2} \mathrm{eq}$ from a systematic meta analysis of GHG emissions from agricultural products (Poore and Nemecek, 2018), with the remaining 62 percent from biomass recovery.

As with the total numbers, ruminant meat has the largest emissions intensities, per unit (289 kg $\mathrm{CO}_{2}$ eq per $\mathrm{kg}$ consumer product) and per protein (1,279 $\mathrm{kg} \mathrm{CO}$ eq per $\mathrm{kg}$ protein). The most efficient animal products on a per protein basis are chicken meat (56 $\mathrm{kg} \mathrm{CO}_{2} \mathrm{eq}$ per $\mathrm{kg}$ protein) and eggs ( $49 \mathrm{~kg} \mathrm{CO}$ eq per $\mathrm{kg}$ protein), roughly 25 times lower than per protein emissions intensities for ruminant meat.

To connect these numbers to other sources of GHGs, we converted these emissions intensities to distances one would have to drive a typical 2021 model year gas-fueled passenger car to produce the same emissions, based on a full life-cycle analysis of auto emissions (Bieker, 


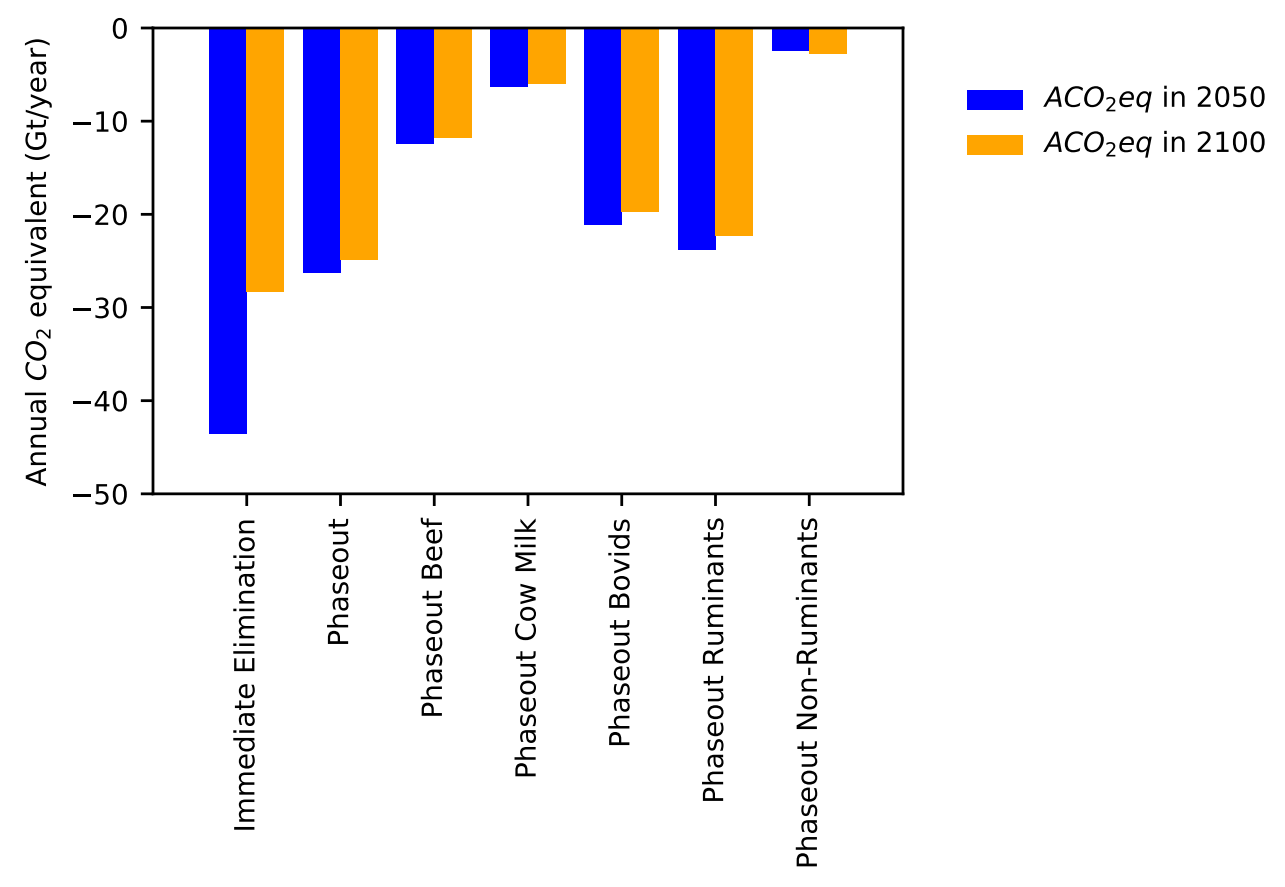

Figure 5. Annual $\mathrm{CO}_{2}$ equivalents $\left(\mathrm{aCO}_{2} \mathrm{eq}\right)$ of dietary scenarios

Bars show sustained reduction in annual $\mathrm{CO}_{2}$ emissions necessary to equal cumulative reduction in radiative forcing of given scenario in 2050 (blue) and 2100 (orange). 


\section{A}

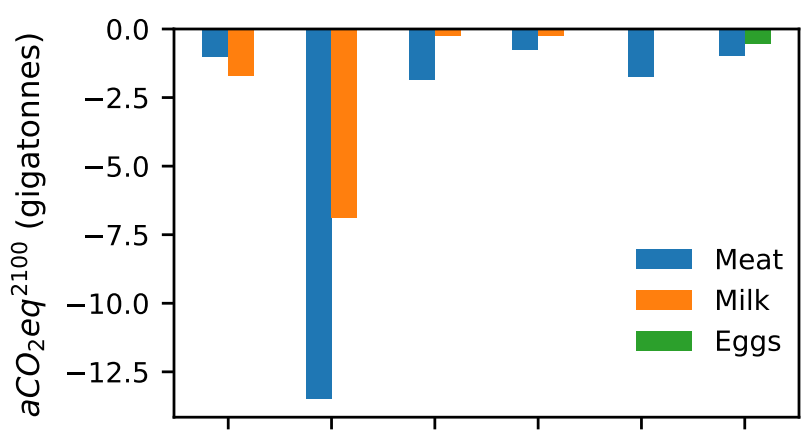

B

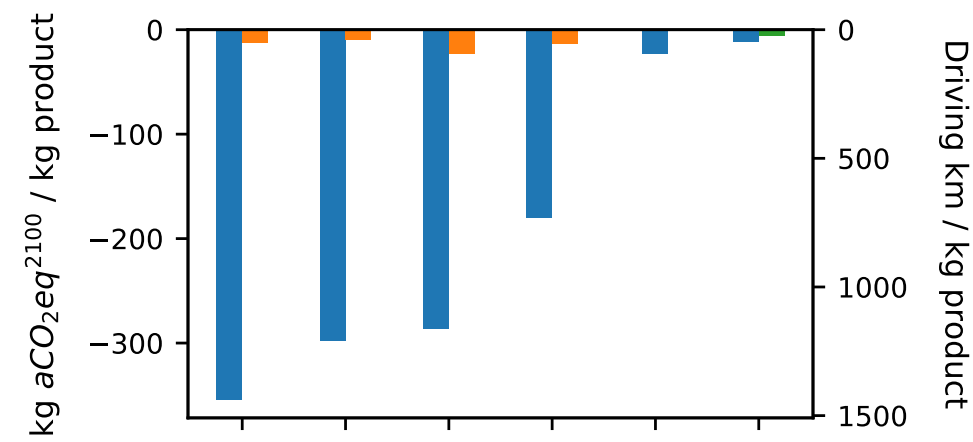

C

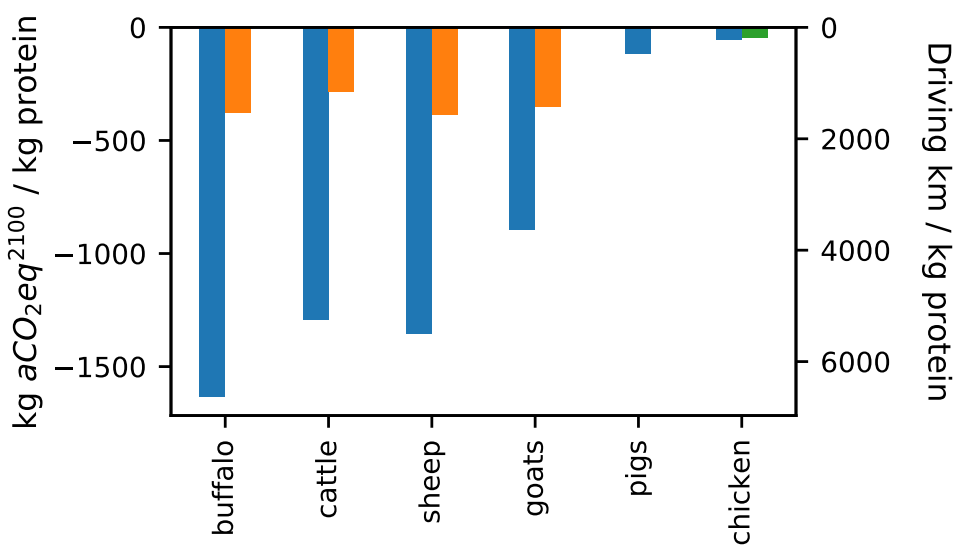

Figure 6. Emission equivalents and Emission Intensities of livestock products.

(A) Total annualized $\mathrm{CO}_{2}$ equivalents through $2100, \mathrm{aCO}_{2} e q^{2100}$, for all tracked animal products, and Emission Intensities based on $\mathrm{aCO}_{2} \mathrm{eq}^{2100}$ on a per unit production (B) or per unit protein (C) basis. For (B) and (C) we also convert the values to driving equivalents using a value of $0.254 \mathrm{~kg} \mathrm{CO}$ eq per $\mathrm{km}$ driven of an internal combustion engine fueled sedan in the United States from life cycle analyses desribed in (Bieker, 2021). 
2021)(Figures 6B and C). One kg of beef, for example, has the same emissions impact as driving $1,172 \mathrm{~km}$ in a typical US car (or 339 miles per pound).

\section{Sensitivity to assumptions}

Our default model assumes a gradual phaseout of animal agriculture over a period of 15 years, producing an $\mathrm{aCO}_{2} \mathrm{eq}^{2100}$ of $-24.8 \mathrm{Gt} /$ year . If we assume immediate elimination (Figure 2-S1), the $\mathrm{aCO}_{2} \mathrm{eq}^{2100}$ is $-28.3 \mathrm{Gt} /$ year (Figure $7 \mathrm{~A}$ ), a $14 \%$ increase in magnitude of the effect. If we assume a phaseout over 30 years (Figure 2-S2), the $\mathrm{aCO}_{2} \mathrm{eq}^{2100}$ is $-21.3 \mathrm{Gt} /$ year (Figure $7 \mathrm{~A}$ ), a $14 \%$ reduction.

Our default model also assumes that biomass will recover linearly over 30 years, following (Hayek et al., 2021), but there is considerable uncertainty in the literature, with estimates ranging from 25 to 70 years (Lennox et al., 2018; N'Guessan et al., 2019; Poorter et al., 2016). If we assume recovery takes 50 years (Figure 2-S3), the $\mathrm{aCO}_{2} \mathrm{eq}^{2100}$ is $-22.4 \mathrm{Gt} /$ year, and if it takes 70 years (Figure 2-S4), the $\mathrm{aCO}_{2} \mathrm{eq}^{2100}$ is $-20.1 \mathrm{Gt} /$ year, or reductions of $10 \%$ and $19 \%$ respectively (Figure 7B). We also note that passive recovery is not the only option. Further research is required to define optimal management practices for recovery of ecosystems currently impacted by animal agriculture and to estimate the rate and magnitude of their potential impact on climate. But there is evidence that deliberate, active management of ecosystem recovery to optimize for carbon sequestration could accelerate and increase the magnitude of carbon storage on land transitioning from intensive agricultural use (Griscom et al., 2017).

Estimates of the biomass recovery potential of land currently used for animal agriculture have a high degree of uncertainty. Using the low estimate (Figure 2-S5) of (Hayek et al., 2021), which addresses uncertainty in above-ground biomass yields an $\mathrm{aCO}_{2} \mathrm{eq}^{2100}$ of $-21.2 \mathrm{Gt} /$ year (Figure $7 \mathrm{C})$, a $14 \%$ reduction in magnitude relative to the median value from Hayek. Using the high 
A

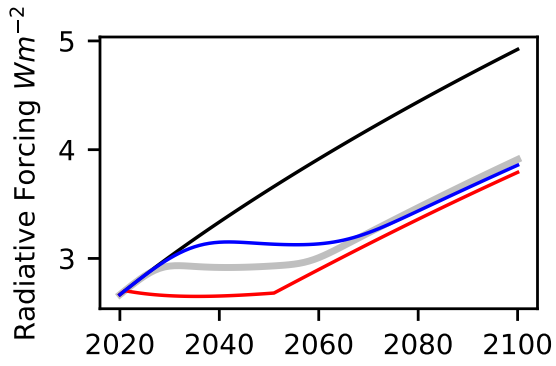

Business As Usual

15 year Phaseout

Immediate Elimination

30 year Phaseout

B

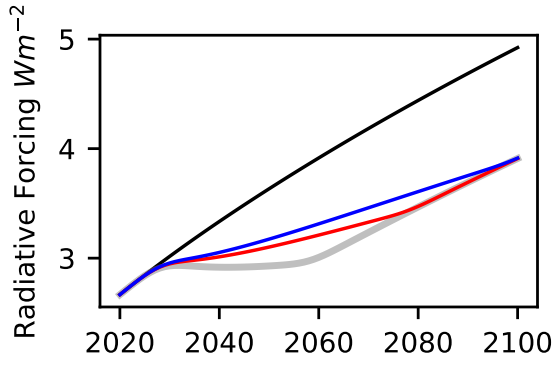

Business As Usual

30 year Carbon Recovery

50 year Carbon Recovery

70 year Carbon Recovery

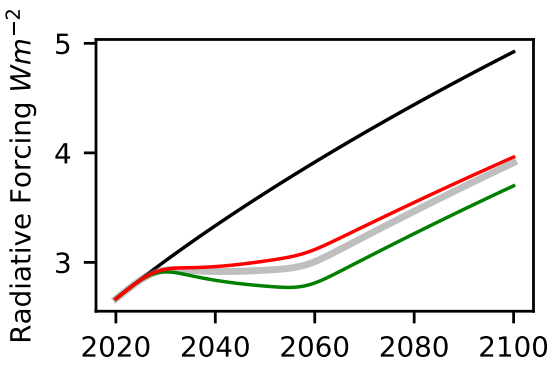

Business As Usual

Hayek Mean COC

Hayek High COC

Hayek Low COC

D

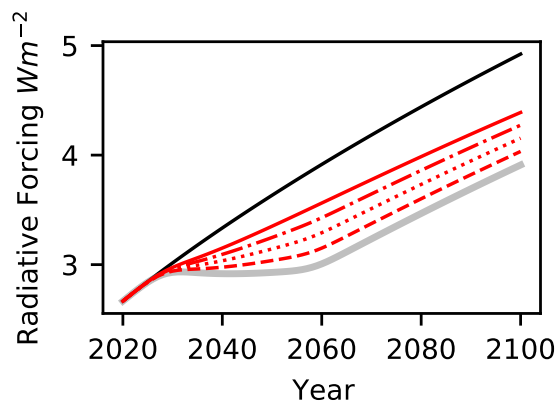

Business As Usual

Full Carbon Recovery

-- - 75\% Carbon Recovery

....... 50\% Carbon Recovery

-. - 25\% Carbon Recovery

- No Carbon Recovery

Figure 7. Sensitivity of impact of phaseout of animal agriculture to model assumptions.

The grey line in each plot is the default scenario of 15 year phaseout, 30 year carbon recovery, livestock emissions from FAOSTAT, and a diverse plant replacement diet based on (Xu et al., 2021). (A) Effect of the immediate elimination of animal agriculture (red line) or a slower, 30 year, phaseout (blue line). (B) Effect of slower carbon recovery reaching completion after 50 years (red line) or 70 years (blue line). (C) Effect of using high (green line) or low (red line) estimates of above ground carbon recovery from (Hayek et al., 2020). (D) Effect of reducing either the efficiency or extent of carbon recovery. 
estimate (Figure 2-S6) of (Hayek et al., 2021) yields an $\mathrm{aCO}_{2} \mathrm{eq}^{2100}$ of $-28.1 \mathrm{Gt} /$ year (Figure 7C), an increase in magnitude of $13 \%$ increase.

A major area of uncertainty not addressed by (Hayek et al., 2021) is the extent to which the carbon recovery potential of land that transitions away from use in animal agriculture would be realized in the face of other land use pressures. (Hayek et al., 2021) accounts for the land needed to replace animal derived foods in the global diet, but not for other potential large-scale non-food uses such as biofuel production. While it is beyond the scope of this work to model these uses explicitly, Figure 7D shows the expected RF trajectories if we assume reduced recovery fractions of 25\% (Figure 2-S7), 50\% (Figure 2-S8), 75\% (Figure 2-S9) and 100\% (Figure 2-S10), which yield $\mathrm{aCO}_{2} \mathrm{eq}^{2100}$ of $-21.6,-18.3,-15.0$, and $-11.6 \mathrm{Gt} /$ year respectively, highlighting the importance of carbon recovery in realizing the climate potential of ending animal agriculture. It is important to note that there is substantial variance in the biomass potential between regions and ecosystems, and recent modeling work by (Strassburg et al., 2020) that half of the biomass recovery potential of land currently used for animal agriculture could be realized by restoration of $25 \%$ of the relevant land.

Our estimate of global emissions due to animal agriculture based on FAO data and analyses of 1.6 $\mathrm{Gt} \mathrm{CO}_{2}, 122 \mathrm{Mt} \mathrm{CH}_{4}$ and 7.0 Mt N $\mathrm{M}_{2} \mathrm{O}$ differ in key ways from recent estimates of (Xu et al., 2021) of 3.2 $\mathrm{Gt} \mathrm{CO}_{2}, 102 \mathrm{Mt} \mathrm{CH}_{4}$ and 3.9 Mt N $\mathrm{N}_{2} \mathrm{O}$. Using these emissions estimates for livestock (Figure 2-S11) yields an $\mathrm{aCO}_{2} \mathrm{eq}^{2100}$ of PHASE-POD of $-23.6 \mathrm{Gt} /$ year (Figure 7-S1A), a $5 \%$ decrease in magnitude.

The models described above assume that the protein currently obtained from animal products would be replaced with a diverse plant based diet, scaled to replace animal products on a protein basis, and agriculture emissions data from FAOSTAT. We considered as an alternative emissions projected emissions from a diverse plant based diet based on data from (Xu et al., 
2021), scaled to replace animal products on a protein basis. This replacement diet (Figure 2-S12) yields an $\mathrm{aCO}_{2} \mathrm{eq}^{2100}$ for PHASE-POD of animal agriculture of $-23.7 \mathrm{Gt} /$ year (Figure 7-S1B), a 5\% decrease in magnitude.

This analysis only considered consumption of terrestrial animal products, neglecting emissions and land use (via feed production) associated with seafood capture and aquaculture. While the land and emissions impact of seafood consumption has received comparably little attention, several studies have pointed to at least $500 \mathrm{Mt}$ of $\mathrm{CO}_{2}$ equivalent emissions per year from seafood (MacLeod et al., 2020; Parker et al., 2018; Poore and Nemecek, 2018). Recent work has also suggested that the disruption of carbon storage due to seafood harvesting via trawling repartitions from 0.58 up to $1.47 \mathrm{Gt} \mathrm{CO}_{2}$ equivalent carbon from sediment into the water column, with the potential to drive atmospheric increases of similar magnitude (Sala et al., 2021).

Widely used climate models consider temporal and spatial variation in emissions; feedback between a changing climate and anthropogenic and natural emissions, carbon sequestration, atmospheric chemistry and warming potential; the impact of climate on human social, political and economic behavior. Ours does not. We ran our model on emissions data from the pathways described in (Riahi et al., 2017) and compared our atmospheric level and RF outputs to theirs, and found them to be in broad qualitative agreement. Thus, while other models could provide more precise estimates, we do not believe they would alter our major conclusions.

\section{Discussion}

Our analysis has provided a quantitative estimate of the potential climate impact of a hypothetical, radical global change in diet and agricultural systems. We have shown that the combined benefits of removing major global sources of $\mathrm{CH}_{4}$ and $\mathrm{N}_{2} \mathrm{O}$, and allowing biomass to 
recover on the vast areas of land currently used to raise and feed livestock, would be equivalent to a sustained reduction of $25 \mathrm{Gt} /$ year of $\mathrm{CO}_{2}$ emissions.

Crucially eliminating the use of animals as food technology would produce substantial negative emissions of all three major GHGs, a necessity, as even the complete replacement of fossil fuel combustion in energy production and transportation will no longer be enough to prevent warming of $1.5^{\circ} \mathrm{C}$ (Clark et al., 2020; IPCC, 2018).

The transition away from animal agriculture will face many obstacles and create many challenges. Meat, dairy and eggs are a major component of global human diets (FAO, 2021), and the raising of livestock is integral to rural economies worldwide, with more than a billion people making all or part of their living from animal agriculture.

Although animal products currently provide, according to the most recent data from FAOSTAT, $18 \%$ of the calories, $40 \%$ of the protein and $45 \%$ of the fat in the human food supply, they are not necessary to feed the global population. An estimated 400 million people already live on entirely plant-based diets, and existing crops could replace the calories, protein and fat from animals with a vastly reduced land, water, GHG and biodiversity impact, requiring only minor adjustments to optimize nutrition (Springmann et al., 2018b).

The economic and social impacts of a global transition to a plant based diet would be acute in many regions and locales (Newton and Blaustein-Rejto, 2021), a major obstacle to their adoption. It is likely that substantial global investment will be required to ensure that the people who currently make a living from animal agriculture do not suffer when it is reduced or replaced. And, while it is expected that the phaseout of animal agriculture would lead to global increases in food availability as edible crops cease to be diverted for animal feed (Vågsholm et al., 2020), investment will also be required to prevent local food insecurity in regions currently heavily reliant on animal based foods. But, in both cases, these investments must be compared to the 
economic and humanitarian disruptions of significant global warming (Howard and Sylvan, 2021; Stehfest et al., 2019).

Although, as discussed above, there are many uncertainties in our estimates, our assumption that "business as usual" means animal agriculture will continue at current levels was highly conservative, as rising incomes are driving ongoing growth in global animal product consumption (OECD-FAO Agricultural Outlook 2020-2029). If the current diet of wealthy industrialized countries (OECD) were extended to the global population, and land use rates remained the same, an additional 35 million $\mathrm{km}^{2}$ - an area roughly equal to the combined area of Africa and Australia - would be needed to support the required growth in livestock populations.

While such an expansion may seem implausible, even partial destruction of Earth's critical remaining native ecosystems would have catastrophic impacts not just on the climate, but on global biodiversity (IPBES, 2019; Newbold et al., 2015; World Wildlife Fund, 2020) and human health (Clark et al., 2019; Maron et al., 2018; Oliver et al., 2015; Satija et al., 2017; Springmann et al., 2016; Strassburg et al., 2020; Tilman and Clark, 2014).

Given these realities, even with the many challenges that upending a trillion dollar a year business and transforming the diets of seven billion people presents, it is surprising that changes in food production and consumption are not at the forefront of proposed strategies for fighting climate change. Although all of the strategies presented as part of the recent Intergovernmental Panel on Climate Change (IPCC) report on steps needed to keep global warming below $1.5^{\circ} \mathrm{C}$ (IPCC, 2018) acknowledge the need for significant negative emissions, none propose even a reduction in per capita livestock consumption below current levels (Figure 8). 
bioRxiv preprint doi: https://doi.org/10.1101/2021.04.15.440019; this version posted October 12, 2021. The copyright holder for this preprint (which was not certified by peer review) is the author/funder, who has granted bioRxiv a license to display the preprint in perpetuity. It is made available under aCC-BY 4.0 International license.

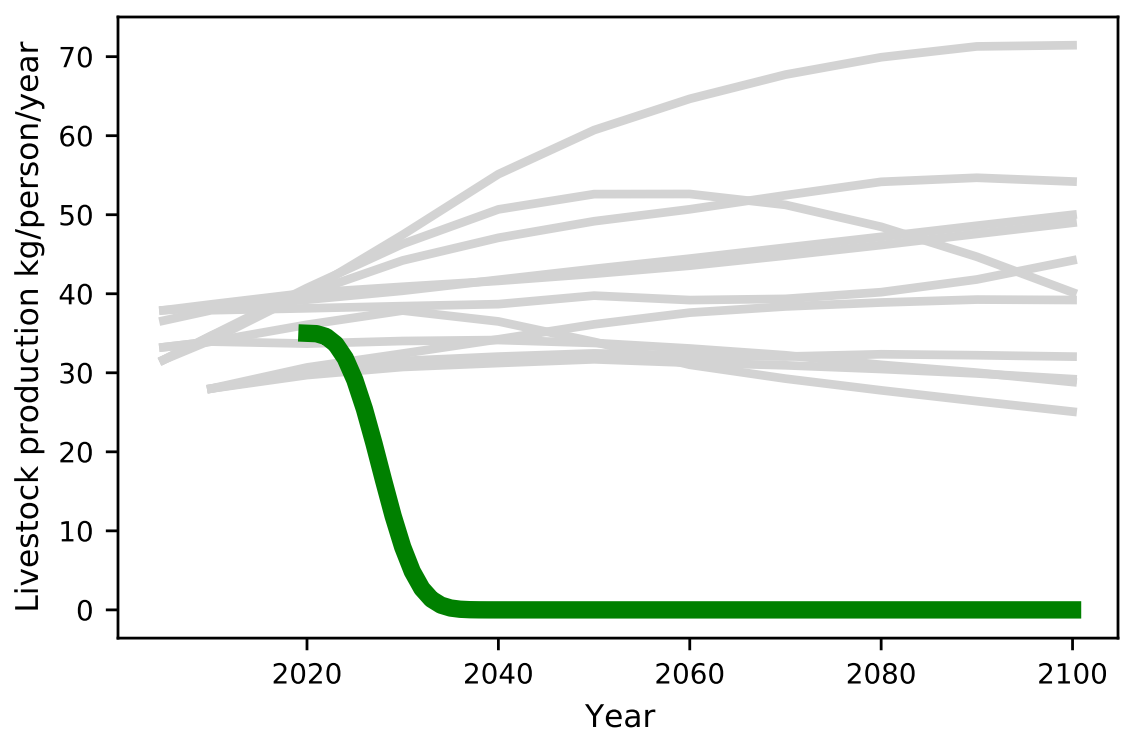

IPCC 1.5C Scenarios

This work

Figure 8. Projected per capita livestock production in SSP/IAM RF 1.9 scenarios.

We downloaded data for the Shared Socioeconomic Pathways (SSPs) (Riahi et al., 2017) from the SSP database (Version 2.0; last updated December 2018), and plot here the inferred per capita livestock production for scenarios meant to reach an RF target of 1.9 in 2100 . While there is widespread acknowledgement of the impact that ongoing animal agriculture has on the climate, it is notable that most of these scenarios, which represent the most aggressive proposed mitigation strategies in this modeling framework, anticipate an increase in per capita livestock consumption, and none anticipate any significant reduction below current levels, in contrast to the complete elimination we propose here. 
Even if the negative emission technology they anticipate, BECCS (bio-energy combined with carbon capture and storage), proves to be viable at scale, it will require large amounts of land (Anderson and Peters, 2016), and the only way to get that land without massive collateral damage is by displacing animal agriculture, primarily land-intensive ruminants. Thus, all currently viable solutions to the climate crisis likely require some form of large scale dietary change.

It is important to emphasize that, as great as the potential climate impact of ending animal agriculture may be, even if it occurred, and even if all of the benefits we anticipate were realized, it would not be enough on its own to prevent catastrophic global warming. Rather we have shown that global dietary change provides a powerful complement to the indispensable transition from fossil fuels to renewable energy systems. The challenge we face is not choosing which to pursue, but rather in determining how best to overcome the many social, economic and political challenges incumbent in implementing both as rapidly as possible. 


\begin{tabular}{|c|c|c|c|c|c|c|c|c|c|c|c|}
\hline Species & Commodity & $\begin{array}{l}\text { Primary } \\
\text { Production } \\
\text { tonnes }\end{array}$ & $\begin{array}{l}\text { Protein } \\
\text { Production } \\
\text { tonnes } \\
\text { protein }\end{array}$ & $\begin{array}{l}\text { Emissions } \\
\qquad \mathrm{CO}_{2}\end{array}$ & $\begin{array}{c}\text { Emissions } \\
\mathrm{CH}_{4} \\
\mathrm{Mt}\end{array}$ & $\begin{array}{c}\text { Emissions } \\
\qquad \mathrm{N}_{2} \mathrm{O} \\
\mathrm{Mt}\end{array}$ & $\begin{array}{l}\text { Land } \\
\text { Use }\end{array}$ & aCO2eq & $\begin{array}{l}\text { Emissions } \\
\text { Intensity } \\
\text { kg aCO2 per } \\
\text { kg }\end{array}$ & $\begin{array}{l}\text { Emissions } \\
\text { Intensity } \\
\text { kg aCO2eq per } \\
\text { kg protein }\end{array}$ & $\begin{array}{c}\text { Driving } \\
\text { Equivalents } \\
\text { km driven per } \\
\text { kg }\end{array}$ \\
\hline Buffalo & Meat & $4,290,212$ & 619,200 & 29 & 5.00 & 0.20 & 1.0 & -1.0 & -354 & -1635 & 1394 \\
\hline Cattle & Meat & $67,893,363$ & $10,435,590$ & 236 & 49.30 & 2.41 & 17.1 & -13.5 & -298 & -1292 & 1172 \\
\hline Sheep & Meat & $9,648,245$ & $1,354,398$ & 32 & 5.02 & 0.33 & 2.5 & -1.8 & -286 & -1353 & 1126 \\
\hline Goats & Meat & $6,128,372$ & 821,383 & 21 & 3.34 & 0.11 & 0.8 & -0.7 & -180 & -893 & 709 \\
\hline Pigs & Meat & $110,102,495$ & $14,447,438$ & 278 & 7.19 & 0.62 & 1.6 & -1.7 & -23 & -119 & 92 \\
\hline Chickens & Meat & $123,898,557$ & $17,393,440$ & 306 & 0.29 & 0.52 & 1.3 & -1.0 & -12 & -56 & 47 \\
\hline Ducks & Meat & $7,363,110$ & $1,044,797$ & 27 & 0.02 & 0.05 & 0.1 & -0.1 & -16 & -73 & 62 \\
\hline Buffalo & Milk & $133,752,296$ & $4,510,017$ & 119 & 10.87 & 0.45 & 1.2 & -1.7 & -13 & -376 & 50 \\
\hline Cattle & Milk & $712,883,270$ & $23,889,273$ & 338 & 37.63 & 1.78 & 6.3 & -6.9 & -10 & -287 & 38 \\
\hline Sheep & Milk & $10,172,020$ & 624,048 & 10 & 1.72 & 0.12 & 0.1 & -0.2 & -23 & -385 & 92 \\
\hline Goats & Milk & $18,752,379$ & 702,585 & 10 & 1.74 & 0.06 & 0.2 & -0.2 & -13 & -351 & 52 \\
\hline Chickens & Eggs & $88,361,696$ & $10,982,733$ & 159 & 0.57 & 0.35 & 0.6 & -0.5 & -6 & -49 & 24 \\
\hline
\end{tabular}

Table 1. Product-specific emissions, land use and inferred impacts

Primary production data aggregated from FAOSTAT for 2019. Protein production data calculated from primary production data and protein conversion factors inferred from GLEAM. Emissions data based on protein production data and emission intensities from GLEAM. Land use data calculated from FAOSTAT protein production data and product-specific land use data from (Poore and Nemecek, 2018). Annualized $\mathrm{CO}_{2}$ equivalent emissions are for 2100 and calculated from atmospheric modeling results. 


\section{Methods}

\section{Data and Code Availability}

Analyses were carried out in Python using Jupyter notebooks. All data, analyses and results presented here are available at github.com/mbeisen/LivestockClimatelmpact.

\section{Updating Estimates of Emissions from Animal Agriculture}

We obtained country, species, herd and product type specific $\mathrm{CO}_{2}, \mathrm{CH}_{4}$ and $\mathrm{N}_{2} \mathrm{O}$ emission data for terrestrial livestock from the public version of GLEAM 2.0 (MacLeod et al., 2018) downloaded from http://www.fao.org/gleam/results/en/. GLEAM contains data for cattle, buffalo, sheep, goats, pigs and chickens, and attributes emissions to meat, milk and eggs. Although GLEAM further breaks down emissions based on herd type and production system, we used aggregate data for all herds and production types in the country. We did not include $\mathrm{CO}_{2}$ emissions linked to land-use change, as this is associated with increases in livestock production which are explicitly not considered by our model.

We obtained livestock production data for 2019 (the most recent year available) from the "Production_LivestockPrimary" datafile in FAOSTAT (FAO, 2021). We extracted from Production_LivestockPrimary the amount (in tonnes), for all countries, of primary domestic production of meat from cattle, buffalo, sheep, goat, pig, chicken and duck, milk from cows, buffalo, sheep and goat, and eggs from poultry. We computed meat and protein yields from the carcass weight data reported by GLEAM.

We scaled the GLEAM emission data to current production data from FAOSTAT, using GLEAM data for entire herds based on carcass weight for meat, and production weight for milk and eggs. As GLEAM does not provide data for ducks, we used values for chicken. The scaling was 
done using country-specific livestock production data from FAOSTAT and regional data from GLEAM.

\section{Estimating species-specific land use}

We combined livestock production data with average species and product-specific land use data from (Poore and Nemecek, 2018) to estimate species, product and country-specific land use data associated with animal agriculture. We use data for cattle meat for buffalo meat, and cow milk for milk from buffalo, goat and sheep. The data are reported in $\mathrm{mm}^{2}$ (year) $\left(100 \mathrm{~g}_{\text {protein }}\right)^{-1}$ except for milk which is reported in $m^{2}$ (year) $(\text { liter })^{-1}$ which we convert to $m^{2}$ (year) $(k g \text { primary production })^{-1}$ using conversion factors inferred from GLEAM, which reports both protein and primary production data.

The total land use for animal agriculture inferred from this analysis is 33.7 million $\mathrm{km}^{2}$, almost identical to the 33.2 million $\mathrm{km}^{2}$ estimated by (Hayek et al., 2021) from satellite imagery.

\section{Emissions from Agriculture}

We used the Environment_Emissions_by_Sector_E_All_Data_(Normalized) data table from FAOSTAT, projecting from the most recent year of 2017 to 2019 by assuming that the average annual growth from 2000 to 2017 continued in 2018 and 2019.

\section{$\underline{\text { Replacement Diets }}$}

We modeled agricultural emissions under a business as usual (BAU) diet as remaining at 2019 levels. When modeling reductions in livestock consumption, we replaced livestock products with a diverse plant-based diet based on data on current crop consumption from FAOSTAT, scaling non-livestock agricultural emission intensities for unit protein (inferred by subtracting non-land use associated livestock emissions from non-land use associated total agricultural emissions 
and dividing by total protein yield) by protein required to match that provided by the livestock being replaced. As an alternative we used emission intensities from (Xu et al., 2021) as described in the Sensitivity section. For diets involving the removal of one or more specific animal products, we scaled these dietary replacement emissions by the fraction of animal protein obtained from that product, and scaled biomass recovery by the fraction of animal agriculture land attributed to that product.

\section{Replacement Scenarios}

In all scenarios we assume annual non-agricultural emissions remain fixed at 2019 levels through 2100. For a BAU diet we added in total agricultural emissions from the FAOSTAT "Emissions Shares" data table, effectively fixing total emissions at 2019 levels. We assumed a 15 year phaseout of animal agriculture with an accelerated rate of conversion from BAU to

PHASE-POD. The specific formula we use is $f($ year $)=e^{-5^{*}\left(\frac{\text { year }-2020}{15}\right)^{3}}$

yielding the conversion dynamics shown below:

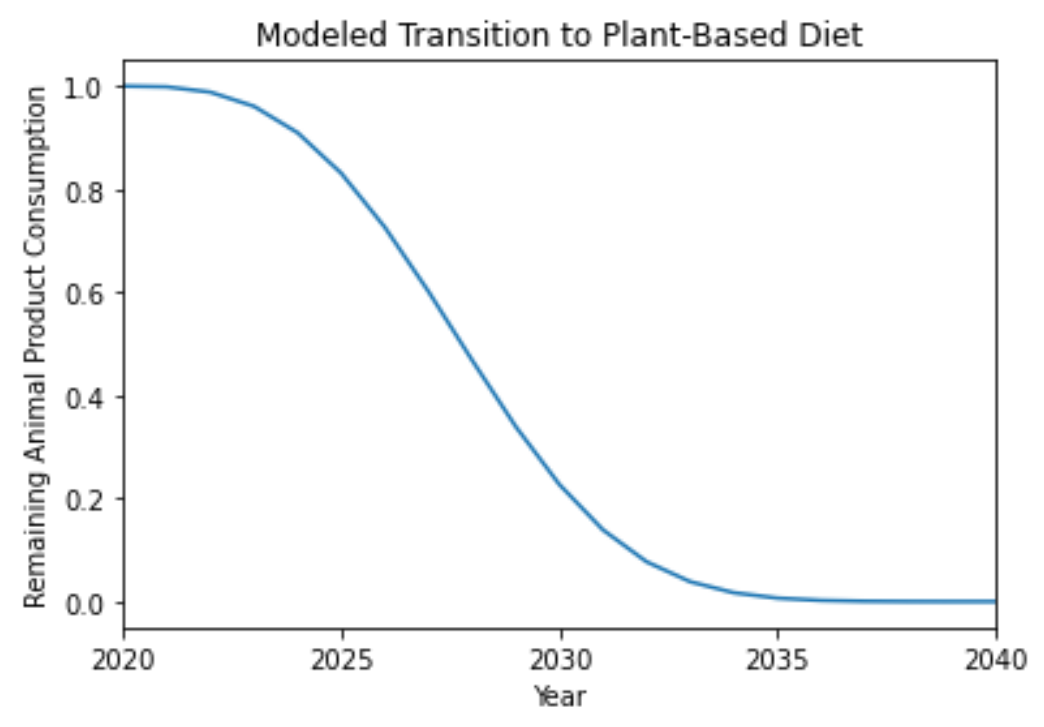


We also include in the supplemental data a version of the analysis in which the hypothetical transition is instantaneous (IMM-POD).

As the transition from BAU to PHASE-POD occurs, agriculture linked emissions are set to

$$
E_{\text {food }}=f E_{B A U}+(1-f) E_{P O D}
$$

Where $f$ is the fraction of the global diet that is still BAU.

We assume that, when animal-derived food consumption is reduced in a year by a fraction $\Delta f$, that carbon recovery on a corresponding fraction of land begins immediately and continues at a constant rate until it reaches $100 \%$ after 30 years (see also Figure 7 for 50 and 70 year recovery timelines).

Converting between emissions and atmospheric concentrations of GHGs

The total mass of gas in the atmosphere is $5.136 * 10^{21} \mathrm{~g}$, at a mean molecular weight of 28.97 $\mathrm{g} /$ mole (Walker, 1977), or $1.77 \mathrm{e}+20$ total moles of gas. Hence $1 \mathrm{ppb}$ is $1.77^{*} 10^{11}$ moles and 1 ppm is $1.77 * 10^{14}$ moles.

We therefore use conversions from mass in $\mathrm{Gt}$ to $\mathrm{ppb} / \mathrm{ppm}$ as follows:

$$
\begin{aligned}
& \mathrm{CO}_{2} \mathrm{ppm}=\mathrm{CO}_{2} \mathrm{Gt} * \frac{10^{15} \mathrm{~g}}{\mathrm{Gt}} * \frac{1 \mathrm{~mole}}{44 \mathrm{~g}} * \frac{1 \mathrm{ppm}}{1.77^{* 10^{14} \mathrm{~mole}}} * f{ }_{\text {sink }} \\
& \mathrm{CH}_{4} \mathrm{ppb}=\mathrm{CH}_{4} \mathrm{Mt} * \frac{10^{12} \mathrm{~g}}{\mathrm{Mt}} * \frac{1 \mathrm{~mole}}{16 \mathrm{~g}} * \frac{1 \mathrm{ppb}}{1.77^{* 10^{11} \mathrm{~mole}}} \\
& \mathrm{~N}_{2} \mathrm{O} \mathrm{ppb}=\mathrm{N}_{2} \mathrm{OMt} * \frac{10^{12} \mathrm{~g}}{\mathrm{Mt}} * \frac{1 \mathrm{~mole}}{44 \mathrm{~g}} * \frac{1 \mathrm{ppb}}{1.77^{* 11} 10^{11} \mathrm{~mole}}
\end{aligned}
$$


We use an $f_{\text {sink }}$ value of 0.50 reflecting the observation that approximately half of terrestrial $\mathrm{CO}_{2}$ emissions end up in land or ocean sinks rather than the atmosphere (Houghton, 2003).

\section{Estimating global non-anthropomorphic emissions}

Both $\mathrm{CH}_{4}$ and $\mathrm{N}_{2} \mathrm{O}$ decay at appreciable rates, with half-lives of approximately 9 years for $\mathrm{CH}_{4}$ (Morgenstern et al., 2017) and 115 years for $\mathrm{N}_{2} \mathrm{O}$ (Prather et al., 2015), although these estimates are being continuously updated (Saunois et al., 2020). We balanced the corresponding decay equations against historical emissions and atmospheric levels, inferring unaccounted for and presumably non-anthropogenic sources leading to mole fraction equivalent increases of $\mathrm{CH}_{4}$ of $25 \mathrm{ppb} /$ year and $\mathrm{N}_{2} \mathrm{O}$ of $1.0 \mathrm{ppb} /$ year.

\section{Projections of Atmospheric Gas Levels}

We ran projections on an annual basis starting in 2020 and continuing through 2100 . For each gas:

$$
P_{\text {gas }}^{\text {year }+1}=P_{\text {gas }}^{\text {year }}\left(1-A_{\text {gas }}\right)+E_{\text {gas }}^{\text {year }}+N_{\text {gas }}
$$

where:

$P_{\text {gas }}^{\text {year }}$ is the atmospheric concentration of gas in year in ppb for $\mathrm{CH}_{4}$ and $\mathrm{N}_{2} \mathrm{O}$ and ppm for $\mathrm{CO}_{2}$

$A_{\text {gas }}$ is the annual decay of gas and is equal to $\left(\frac{1}{2}\right)^{\frac{1}{H_{g a s}}}$ where $H_{\text {gas }}$ is the half-life of gas (we assume that $\mathrm{CO}_{2}$ does not decay)

$$
H_{\mathrm{CH}_{4}}=9.0 \text { years } H_{\mathrm{N}_{2} \mathrm{O}}=115.0 \text { years }
$$


$E \underset{\text { gas }}{\text { year }}$ is the emissions of gas in year converted to atmospheric ppb for $\mathrm{CO}_{2}$ and $\mathrm{N}_{2} \mathrm{O}$ and ppm for $\mathrm{CO}_{2}$ as described above

$N_{\text {gas }}$ is the constant term to account for emissions not captured in $E$

$$
N_{\mathrm{CH}_{4}}=25.0 \mathrm{ppb} \quad \mathrm{N}_{\mathrm{N}_{2} \mathrm{O}}=1.0 \mathrm{ppb}
$$

Starting conditions were obtained from the US National Ocean and Atmospheric Administration Global Monitorial Laboratory (“Carbon Cycle Greenhouse Gases,” n.d.):

$$
P_{\mathrm{CO}_{2}}^{2020}=414.2 p p m \quad P_{\mathrm{CH}_{4}}^{2020}=1879.1 p p b \quad P_{\mathrm{N}_{2} \mathrm{O}}^{2020}=333.0 \mathrm{ppb}
$$

\section{Radiative Forcing}

We adopt the commonly used formula for radiative forcing (RF) which derives from (Myhre et al., 1998; Ramaswamy et al., 2001) as modified in the climate modeling program MAGICC6 (Meinshausen et al., 2011).

Given atmospheric concentration of $\mathrm{Cppm} \mathrm{CO} 2, \mathrm{Mppb} \mathrm{CH}_{4}$ and $N \mathrm{ppb} \mathrm{N}_{2} \mathrm{O}$

$$
\begin{aligned}
& R F(C, M, N)=\Delta F=\Delta F_{C_{2}}+\Delta F_{C_{4}}+\Delta F_{N_{2} O} \\
& \Delta F_{C O_{2}}=\alpha_{C O_{2}} \ln \frac{C}{C_{0}} \\
& \alpha_{C_{2}}=5.35 \\
& \Delta F_{C H_{4}}=\alpha_{C H_{4}}\left(\left(1+\beta_{C H_{4}}\right)\left(\sqrt{M}-\sqrt{M_{0}}\right)+f\left(M, N_{0}\right)+f\left(M_{0}, N_{0}\right)\right)
\end{aligned}
$$




$$
\begin{aligned}
& \alpha_{C_{4}}=0.036 \text { and } \beta_{C_{4}}=0.15 \\
& \Delta F_{N_{2} O}=\alpha_{N_{2} O}\left(\sqrt{N}-\sqrt{N_{0}}+f\left(M_{0}, N\right)+f\left(M_{0}, N_{0}\right)\right) \\
& \alpha_{N_{2} O}=0.12
\end{aligned}
$$

The function $f(m, n)=0.47 \ln \left(1+0.6356\left(\frac{m n}{10^{6}}\right)^{.75}+0.007\left(\frac{m}{10^{3}}\right)\left(\frac{m n}{10^{6}}\right)^{1.52}\right.$ captures the overlap in spectra between $\mathrm{CH}_{4}$ and $\mathrm{N}_{2} \mathrm{O}$.

$C_{0}, M_{0}$ and $N_{0}$ are the preindustrial levels of the corresponding gasses.

$$
C_{0}=278 p p m \quad M_{0}=700 p p b \quad N_{0}=270 p p b
$$

\section{Computing Emissions and Land Carbon Opportunity Cost}

We define the combined emissions and land carbon opportunity cost (ELCOC) of animal agriculture as $2 \Delta C$ where

$$
R F\left(C_{B A U}-\triangle C, M_{B A U}, N_{B A U}\right)=R F\left(C_{P O D^{\prime}}, M_{P O D}, N_{P O D}\right)
$$

The factor of 2 accounts for the half of $\mathrm{CO}_{2}$ emissions that go to terrestrial sinks.

\section{Computing Carbon Emissions Budgets for RF 2.6 and 1.9}

As the RF calculation used in MAGICC6 account for other gasses and effects beyond the three gasses used here, we used multivariate linear regression as implemented in the Python package scikit-learn to predict the complete RF output of MAGICC6 using data data downloaded from the Shared Socioeconomic Pathways (SSPs) (Riahi et al., 2017). The model 
was trained on atmospheric concentrations of $\mathrm{CO}_{2}, \mathrm{CH}_{4}$ and $\mathrm{N}_{2} \mathrm{O}$ to predict the difference between the MAGICC6 RF and the RF calculated using only $\mathrm{CO}_{2}, \mathrm{CH}_{4}$ and $\mathrm{N}_{2} \mathrm{O}$. Then, for timepoints in our scenarios we computed $\mathrm{RF}$ as above from $\mathrm{CO}_{2}, \mathrm{CH}_{4}$ and $\mathrm{N}_{2} \mathrm{O}$ concentrations, and added to this the adjustment from the linear regression model. We use this RF in Figures 3 and 4.

In the SSP file:

$\mathrm{C}=$ Diagnostics $|\mathrm{MAGICC6}|$ Concentration $\mid \mathrm{CO}_{2}$

$\mathrm{M}=$ Diagnostics $|\mathrm{MAGICC6}|$ Concentration $\mid \mathrm{CH}_{4}$ $\mathrm{N}=$ Diagnostics $|\mathrm{MAGICC6}|$ Concentration $\mid \mathrm{N}_{2} \mathrm{O}$

$\Delta \mathrm{F}_{\mathrm{CO}_{2}}=$ Diagnostics $|\mathrm{MAGICC6}|$ Forcing $\mid \mathrm{CO}_{2}$

$\Delta F_{C F_{4}}=$ Diagnostics $|\mathrm{MAGICC6}|$ Forcing $\mid \mathrm{CH}_{4}$

$\Delta F_{N_{2} O}=$ Diagnostics $\mid$ MAGICC6|Forcing $\mid \mathrm{N}_{2} \mathrm{O}$

MAGICC6 RF = Diagnostics|MAGICC6|Forcing

\section{$\underline{\mathrm{aCO}}_{2} \underline{\text { eq }}$}

To compute $\mathrm{aCO}_{2} \mathrm{eq}^{\mathrm{y}}$, the annual $\mathrm{CO}_{2}$ equivalent emission change of each emissions scenario, we first ran scenarios in which annual $\mathrm{CO}_{2}$ emissions were reduced from $50 \mathrm{Gt} /$ year to $1 \mathrm{Gt} / \mathrm{year}$ in increments of $1 \mathrm{Gt} /$ year, then from $1 \mathrm{Gt} /$ year to $10 \mathrm{Mt} / \mathrm{year}$ in increments of $10 \mathrm{Mt} / \mathrm{year}$, and then from $1 \mathrm{MT} /$ year to $100 \mathrm{kT} /$ year in increments of $100 \mathrm{kT} /$ year. For each of these calibration scenarios, and for all years $y$ from 2021 to 2100 , we computed the total RF difference between the calibration scenario and BAU, from 2021 to $y$. 
For each multi-gas emissions scenario, we similarly computed CRFD", and determined what constant level of reduction in annual $\mathrm{CO}_{2}$ emissions alone by interpolation using the CRFD' of the calibration scenarios, and designate this annual $\mathrm{CO}_{2}$ equivalent $\mathrm{aCO}_{2} \mathrm{eq}^{\mathrm{y}}$.

\section{Product equivalents}

To compute per product unit and per protein emissions equivalents, we divided $\mathrm{aCO}_{2} \mathrm{eq}^{2100}$ for immediate elimination of the product (in $\mathrm{kg} \mathrm{CO}_{2} \mathrm{eq} / \mathrm{year}$ ) by the annual production of the product (in $\mathrm{kg}$ production/year) yielding a per product unit emission equivalent measured in $\mathrm{kg} \mathrm{CO}_{2} \mathrm{eq}$ per kg production.

For example, assuming, as our model does, that emissions and land use scale with consumption, if annual beef production were reduced by one tonne $(1,000 \mathrm{~kg})$ per year, it would result in corresponding annual reductions of $-3,476 \mathrm{~kg} \mathrm{CO}_{2},-726 \mathrm{~kg} \mathrm{CH}_{4}$ and $-36 \mathrm{~kg} \mathrm{~N}_{2} \mathrm{O}$, and would initiate 30 year biomass recovery of $6,050,000 \mathrm{~kg}$ of $\mathrm{CO}_{2}$ equivalent carbon on 25.2 ha of land.

The cumulative reduction in RF, through 2100, of such annual emissions reductions and biomass recovery would be equivalent to a $\mathrm{CO}_{2}$ emission reduction of $310,000 \mathrm{~kg} / \mathrm{year}$. The ratio of these two rates, $-310,000 \mathrm{~kg} \mathrm{CO}$ eq/year over $1,000 \mathrm{~kg}$ beef/year yields $-310 \mathrm{~kg} \mathrm{CO}{ }_{2} \mathrm{eq}$ per $\mathrm{kg}$ beef as a measure of the warming impact of one $\mathrm{kg}$ of beef. Adjusting this for the dressing percentage of beef (the values reported by FAO, and used in these calculations, are carcass weight, of which only approximately $2 / 3$ ends up as a consumer product) yields the value shown in Figure 6 of $-470 \mathrm{~kg} \mathrm{CO} 2 \mathrm{eq}$ per $\mathrm{kg}$ consumer beef.

For all meat products we scaled the production amount by a typical dressing percentage of $2 / 3$ to convert to consumer product units. For protein unit equivalents we used protein yields from GLEAM. To convert to driving equivalents we used a value of $.254 \mathrm{~kg} \mathrm{CO}$ eq per $\mathrm{km}$ driven 
bioRxiv preprint doi: https://doi.org/10.1101/2021.04.15.440019; this version posted October 12, 2021. The copyright holder for this preprint (which was not certified by peer review) is the author/funder, who has granted bioRxiv a license to display the preprint in perpetuity. It is made available under aCC-BY 4.0 International license.

taken from a full life cycle analysis of 2021 sedans in the United States from (Bieker, 2021). 


\section{$\underline{\text { References }}$}

Agnoli C, Baroni L, Bertini I, Ciappellano S, Fabbri A, Papa M, Pellegrini N, Sbarbati R, Scarino ML, Siani V, Sieri S. 2017. Position paper on vegetarian diets from the working group of the Italian Society of Human Nutrition. Nutr Metab Cardiovasc Dis 27:1037-1052. doi:10.1016/j.numecd.2017.10.020

Allen MR, Fuglestvedt JS, Shine KP, Reisinger A, Pierrehumbert RT, Forster PM. 2016. New use of global warming potentials to compare cumulative and short-lived climate pollutants. Nat Clim Chang 6:773-776. doi:10.1038/nclimate2998

Allen MR, Shine KP, Fuglestvedt JS, Millar RJ, Cain M, Frame DJ, Macey AH. 2018. A solution to the misrepresentations of $\mathrm{CO} 2$-equivalent emissions of short-lived climate pollutants under ambitious mitigation. npj Climate and Atmospheric Science 1:1-8. doi:10.1038/s41612-018-0026-8

American Dietetic Association, Dietitians of Canada. 2003. Position of the American Dietetic Association and Dietitians of Canada: vegetarian diets. Can J Diet Pract Res 64:62-81. doi:10.3148/64.2.2003.62

Anderson K, Peters G. 2016. The trouble with negative emissions. Science 354:182-183. doi:10.1126/science.aah4567

Bieker G. 2021. A global comparison of the life-cycle greenhouse gas emissions of combustion engine and electric passenger cars. International Council on Clean Transportation.

Cain M, Lynch J, Allen MR, Fuglestvedt JS, Frame DJ, Macey AH. 2019. Improved calculation of warming-equivalent emissions for short-lived climate pollutants. NPJ Clim Atmos Sci 2:29. doi:10.1038/s41612-019-0086-4

Carbon Cycle Greenhouse Gases. n.d. https://gml.noaa.gov/ccgg/

Clark MA, Domingo NGG, Colgan K, Thakrar SK, Tilman D, Lynch J, Azevedo IL, Hill JD. 2020. Global food system emissions could preclude achieving the $1.5^{\circ}$ and $2{ }^{\circ} \mathrm{C}$ climate change targets. Science 370:705-708. doi:10.1126/science.aba7357

Clark MA, Springmann M, Hill J, Tilman D. 2019. Multiple health and environmental impacts of foods. Proc Natl Acad Sci U S A 116:23357-23362. doi:10.1073/pnas.1906908116

Craig WJ, Mangels AR, American Dietetic Association. 2009. Position of the American Dietetic Association: vegetarian diets. J Am Diet Assoc 109:1266-1282.

Cusack DF, Kazanski CE, Hedgpeth A, Chow K, Cordeiro AL, Karpman J, Ryals R. 2021. Reducing climate impacts of beef production: A synthesis of life cycle assessments across management systems and global regions. Glob Chang Biol 27:1721-1736. doi:10.1111/gcb.15509

FAO. 2021. FAOSTAT. FAOSTAT. http://www.fao.org/faostat/en/\#home

Friedlingstein P, O'Sullivan M, Jones MW, Andrew RM, Hauck J, Olsen A, Peters GP, Peters W, Pongratz J, Sitch S, Le Quéré C, Canadell JG, Ciais P, Jackson RB, Alin S, Aragão LEOC, Arneth A, Arora V, Bates NR, Becker M, Benoit-Cattin A, Bittig HC, Bopp L, Bultan S, Chandra N, Chevallier F, Chini LP, Evans W, Florentie L, Forster PM, Gasser T, Gehlen M, Gilfillan D, Gkritzalis T, Gregor L, Gruber N, Harris I, Hartung K, Haverd V, Houghton RA, Ilyina T, Jain AK, Joetzjer E, Kadono K, Kato E, Kitidis V, Korsbakken JI, Landschützer P, Lefèvre N, Lenton A, Lienert S, Liu Z, Lombardozzi D, Marland G, Metzl N, Munro DR, Nabel JEMS, Nakaoka S-I, Niwa Y, O'Brien K, Ono T, Palmer PI, Pierrot D, Poulter B, Resplandy L, Robertson E, Rödenbeck C, Schwinger J, Séférian R, Skjelvan I, Smith AJP, Sutton AJ, Tanhua T, Tans PP, Tian H, Tilbrook B, van der Werf G, Vuichard N, Walker AP, Wanninkhof R, Watson AJ, Willis D, Wiltshire AJ, Yuan W, Yue X, Zaehle S. 2020. Global carbon budget 2020. Earth Syst Sci Data 12:3269-3340. doi:10.5194/essd-12-3269-2020

Gerber PJ, Steinfeld H, Henderson B, Mottet A, Opio C, Dijkman J, Falcucci A, Tempio G. 2013. Tackling Climate Change through Livestock: A global assessment of emissions and mitigation opportunities. Food and Agriculture Organization of the United Nations. 
Griscom BW, Adams J, Ellis PW, Houghton RA, Lomax G, Miteva DA, Schlesinger WH, Shoch D, Siikamäki JV, Smith P, Woodbury P, Zganjar C, Blackman A, Campari J, Conant RT, Delgado C, Elias P, Gopalakrishna T, Hamsik MR, Herrero M, Kiesecker J, Landis E, Laestadius L, Leavitt SM, Minnemeyer S, Polasky S, Potapov P, Putz FE, Sanderman J, Silvius M, Wollenberg E, Fargione J. 2017. Natural climate solutions. Proc Natl Acad Sci U $S$ A 114:11645-11650. doi:10.1073/pnas.1710465114

Hayek MN, Harwatt H, Ripple WJ, Mueller ND. 2021. The carbon opportunity cost of animal-sourced food production on land. Nature Sustainability 4:21-24. doi:10.1038/s41893-020-00603-4

Houghton RA. 2003. 8.10 - The Contemporary Carbon Cycle In: Holland HD, Turekian KK, editors. Treatise on Geochemistry. Oxford: Pergamon. pp. 473-513. doi:10.1016/B0-08-043751-6/08168-8

Howard P, Sylvan D. 2021. Economic_Consensus_on_Climate.pdf. Institute for Policy Integrity. Hristov AN, Oh J, Firkins JL, Dijkstra J, Kebreab E, Waghorn G, Makkar HPS, Adesogan AT, Yang W, Lee C, Gerber PJ, Henderson B, Tricarico JM. 2013a. Special topics--Mitigation of methane and nitrous oxide emissions from animal operations: I. A review of enteric methane mitigation options. J Anim Sci 91:5045-5069. doi:10.2527/jas.2013-6583

Hristov AN, Ott T, Tricarico J, Rotz A, Waghorn G, Adesogan A, Dijkstra J, Montes F, Oh J, Kebreab E, Oosting SJ, Gerber PJ, Henderson B, Makkar HPS, Firkins JL. 2013b. Special topics--Mitigation of methane and nitrous oxide emissions from animal operations: III. A review of animal management mitigation options. J Anim Sci 91:5095-5113. doi:10.2527/jas.2013-6585

Intergovernmental Panel on Climate Change. 2014. Climate Change 2013 - The Physical Science Basis: Working Group I Contribution to the Fifth Assessment Report of the Intergovernmental Panel on Climate Change. Cambridge University Press.

IPBES. 2019. Global assessment report on biodiversity and ecosystem services of the Intergovernmental Science-Policy Platform on Biodiversity and Ecosystem Services. IPBES secretariat, Bonn, Germany.

IPCC. 2018. Global Warming of $1.5^{\circ} \mathrm{C}$. An IPCC Special Report on the impacts of global warming of $1.5^{\circ} \mathrm{C}$ above pre-industrial levels and related global greenhouse gas emission pathways, in the context of strengthening the global response to the threat of climate change, sustainable development, and efforts to eradicate poverty. IPCC.

Jenkins S, Millar RJ, Leach N, Allen MR. 2018. Framing climate goals in terms of cumulative CO2 -forcing-equivalent emissions. Geophys Res Lett 45:2795-2804. doi:10.1002/2017gl076173

Lennox GD, Gardner TA, Thomson JR, Ferreira J, Berenguer E, Lees AC, Mac Nally R, Aragão LEOC, Ferraz SFB, Louzada J, Moura NG, Oliveira VHF, Pardini R, Solar RRC, Vaz-de Mello FZ, Vieira ICG, Barlow J. 2018. Second rate or a second chance? Assessing biomass and biodiversity recovery in regenerating Amazonian forests. Glob Chang Biol

24:5680-5694. doi:10.1111/gcb.14443

Liu S, Proudman J, Mitloehner FM. 2021. Rethinking methane from animal agriculture. CABI Agriculture and Bioscience 2:1-13. doi:10.1186/s43170-021-00041-y

MacLeod MJ, Hasan MR, Robb DHF, Mamun-Ur-Rashid M. 2020. Quantifying greenhouse gas emissions from global aquaculture. Sci Rep 10:11679. doi:10.1038/s41598-020-68231-8

MacLeod MJ, Vellinga T, Opio C, Falcucci A, Tempio G, Henderson B, Makkar H, Mottet A, Robinson T, Steinfeld H, Gerber PJ. 2018. Invited review: A position on the Global Livestock Environmental Assessment Model (GLEAM). Animal 12:383-397. doi:10.1017/S1751731117001847

Maron M, Simmonds JS, Watson JEM. 2018. Bold nature retention targets are essential for the global environment agenda. Nat Ecol Evol 2:1194-1195. doi:10.1038/s41559-018-0595-2

Meinshausen M, Raper SCB, Wigley TML. 2011. Emulating coupled atmosphere-ocean and 
carbon cycle models with a simpler model, MAGICC6 - Part 1: Model description and calibration. Atmos Chem Phys 11:1417-1456. doi:10.5194/acp-11-1417-2011

Montes F, Meinen R, Dell C, Rotz A, Hristov AN, Oh J, Waghorn G, Gerber PJ, Henderson B, Makkar HPS, Dijkstra J. 2013. SPECIAL TOPICS - Mitigation of methane and nitrous oxide emissions from animal operations: II. A review of manure management mitigation options. J Anim Sci 91:5070-5094. doi:10.2527/jas.2013-6584

Morgenstern O, Hegglin MI, Rozanov E, O'Connor FM, Abraham NL, Akiyoshi H, Archibald AT, Bekki S, Butchart N, Chipperfield MP, Deushi M, Dhomse SS, Garcia RR, Hardiman SC, Horowitz LW, Jöckel P, Josse B, Kinnison D, Lin M, Mancini E, Manyin ME, Marchand M, Marécal V, Michou M, Oman LD, Pitari G, Plummer DA, Revell LE, Saint-Martin D, Schofield R, Stenke A, Stone K, Sudo K, Tanaka TY, Tilmes S, Yamashita Y, Yoshida K, Zeng G. 2017. Review of the global models used within phase 1 of the Chemistry-Climate Model Initiative (CCMI). Geosci Model Dev 10:639-671. doi:10.5194/gmd-10-639-2017

Moss RH, Edmonds JA, Hibbard KA, Manning MR, Rose SK, van Vuuren DP, Carter TR, Emori S, Kainuma M, Kram T, Meehl GA, Mitchell JFB, Nakicenovic N, Riahi K, Smith SJ, Stouffer RJ, Thomson AM, Weyant JP, Wilbanks TJ. 2010. The next generation of scenarios for climate change research and assessment. Nature 463:747-756. doi:10.1038/nature08823

Myhre G, Highwood EJ, Shine KP, Stordal F. 1998. New estimates of radiative forcing due to well mixed greenhouse gases. Geophys Res Lett 25:2715-2718. doi:10.1029/98gl01908

Newbold T, Hudson LN, Hill SLL, Contu S, Lysenko I, Senior RA, Börger L, Bennett DJ, Choimes A, Collen B, Day J, De Palma A, Díaz S, Echeverria-Londoño S, Edgar MJ, Feldman A, Garon M, Harrison MLK, Alhusseini T, Ingram DJ, Itescu Y, Kattge J, Kemp V, Kirkpatrick L, Kleyer M, Correia DLP, Martin CD, Meiri S, Novosolov M, Pan Y, Phillips HRP, Purves DW, Robinson A, Simpson J, Tuck SL, Weiher E, White HJ, Ewers RM, Mace GM, Scharlemann JPW, Purvis A. 2015. Global effects of land use on local terrestrial biodiversity. Nature 520:45-50. doi:10.1038/nature14324

Newton P, Blaustein-Rejto D. 2021. Social and Economic Opportunities and Challenges of Plant-Based and Cultured Meat for Rural Producers in the US. Frontiers in Sustainable Food Systems 5:10. doi:10.3389/fsufs.2021.624270

N'Guessan AE, N'dja JK, Yao ON, Amani BHK, Gouli RGZ, Piponiot C, Zo-Bi IC, Hérault B. 2019. Drivers of biomass recovery in a secondary forested landscape of West Africa. For Ecol Manage 433:325-331. doi:10.1016/j.foreco.2018.11.021

Oliver TH, Isaac NJB, August TA, Woodcock BA, Roy DB, Bullock JM. 2015. Declining resilience of ecosystem functions under biodiversity loss. Nat Commun 6:10122. doi:10.1038/ncomms10122

Parker RWR, Blanchard JL, Gardner C, Green BS, Hartmann K, Tyedmers PH, Watson RA. 2018. Fuel use and greenhouse gas emissions of world fisheries. Nat Clim Chang 8:333-337. doi:10.1038/s41558-018-0117-x

Poore J, Nemecek T. 2018. Reducing food's environmental impacts through producers and consumers. Science 360:987-992. doi:10.1126/science.aaq0216

Poorter L, Bongers F, Aide TM, Almeyda Zambrano AM, Balvanera P, Becknell JM, Boukili V, Brancalion PHS, Broadbent EN, Chazdon RL, Craven D, de Almeida-Cortez JS, Cabral GAL, de Jong BHJ, Denslow JS, Dent DH, DeWalt SJ, Dupuy JM, Durán SM, Espírito-Santo MM, Fandino MC, César RG, Hall JS, Hernandez-Stefanoni JL, Jakovac CC, Junqueira AB, Kennard D, Letcher SG, Licona J-C, Lohbeck M, Marín-Spiotta E, Martínez-Ramos M, Massoca P, Meave JA, Mesquita R, Mora F, Muñoz R, Muscarella R, Nunes YRF, Ochoa-Gaona S, de Oliveira AA, Orihuela-Belmonte E, Peña-Claros M, Pérez-García EA, Piotto D, Powers JS, Rodríguez-Velázquez J, Romero-Pérez IE, Ruíz J, Saldarriaga JG, Sanchez-Azofeifa A, Schwartz NB, Steininger MK, Swenson NG, Toledo M, Uriarte M, van Breugel M, van der Wal $H$, Veloso MDM, Vester HFM, Vicentini A, Vieira ICG, Bentos TV, Williamson GB, Rozendaal DMA. 2016. Biomass resilience of Neotropical 
secondary forests. Nature 530:211-214. doi:10.1038/nature16512

Prather MJ, Hsu J, DeLuca NM, Jackman CH, Oman LD, Douglass AR, Fleming EL, Strahan

SE, Steenrod SD, Søvde OA, Isaksen ISA, Froidevaux L, Funke B. 2015. Measuring and modeling the lifetime of nitrous oxide including its variability. $J$ Geophys Res D: Atmos 120:5693-5705. doi:10.1002/2015JD023267

Ramaswamy V, Boucher O, Haigh J, Hauglustaine D, Haywood J, Myhre G, Nakajima T, Shi GY, Solomon S. 2001. Radiative Forcing of Climate ChangeClimate Change 2001: The Scientific Basis. PAO.

Riahi K, van Vuuren DP, Kriegler E, Edmonds J, O’Neill BC, Fujimori S, Bauer N, Calvin K, Dellink R, Fricko O, Lutz W, Popp A, Cuaresma JC, Kc S, Leimbach M, Jiang L, Kram T, Rao S, Emmerling J, Ebi K, Hasegawa T, Havlik P, Humpenöder F, Da Silva LA, Smith S, Stehfest E, Bosetti V, Eom J, Gernaat D, Masui T, Rogelj J, Strefler J, Drouet L, Krey V, Luderer G, Harmsen M, Takahashi K, Baumstark L, Doelman JC, Kainuma M, Klimont Z, Marangoni G, Lotze-Campen H, Obersteiner M, Tabeau A, Tavoni M. 2017. The Shared Socioeconomic Pathways and their energy, land use, and greenhouse gas emissions implications: An overview. Glob Environ Change 42:153-168. doi:10.1016/j.gloenvcha.2016.05.009

Sala E, Mayorga J, Bradley D, Cabral RB, Atwood TB, Auber A, Cheung W, Costello C, Ferretti F, Friedlander AM, Gaines SD, Garilao C, Goodell W, Halpern BS, Hinson A, Kaschner K, Kesner-Reyes K, Leprieur F, McGowan J, Morgan LE, Mouillot D, Palacios-Abrantes J, Possingham HP, Rechberger KD, Worm B, Lubchenco J. 2021. Protecting the global ocean for biodiversity, food and climate. Nature. doi:10.1038/s41586-021-03371-z

Satija A, Bhupathiraju SN, Spiegelman D, Chiuve SE, Manson JE, Willett W, Rexrode KM, Rimm EB, Hu FB. 2017. Healthful and Unhealthful Plant-Based Diets and the Risk of Coronary Heart Disease in U.S. Adults. J Am Coll Cardiol 70:411-422. doi:10.1016/j.jacc.2017.05.047

Saunois M, Stavert AR, Poulter B, Bousquet P, Canadell JG, Jackson RB, Raymond PA, Dlugokencky EJ, Houweling S, Patra PK, Ciais P, Arora VK, Bastviken D, Bergamaschi P, Blake DR, Brailsford G, Bruhwiler L, Carlson KM, Carrol M, Castaldi S, Chandra N, Crevoisier C, Crill PM, Covey K, Curry CL, Etiope G, Frankenberg C, Gedney N, Hegglin MI, Höglund-Isaksson L, Hugelius G, Ishizawa M, Ito A, Janssens-Maenhout G, Jensen KM, Joos F, Kleinen T, Krummel PB, Langenfelds RL, Laruelle GG, Liu L, Machida T, Maksyutov S, McDonald KC, McNorton J, Miller PA, Melton JR, Morino I, Müller J, Murguia-Flores F, Naik V, Niwa Y, Noce S, O'Doherty S, Parker RJ, Peng C, Peng S, Peters GP, Prigent C, Prinn R, Ramonet M, Regnier P, Riley WJ, Rosentreter JA, Segers A, Simpson IJ, Shi H, Smith SJ, Steele LP, Thornton BF, Tian H, Tohjima Y, Tubiello FN, Tsuruta A, Viovy N, Voulgarakis A, Weber TS, van Weele M, van der Werf GR, Weiss RF, Worthy D, Wunch D, Yin Y, Yoshida Y, Zhang W, Zhang Z, Zhao Y, Zheng B, Zhu Q, Zhu Q, Zhuang Q. 2020. The global methane budget 2000-2017. Earth Syst Sci Data 12:1561-1623. doi:10.5194/essd-12-1561-2020

Shine KP. 2000. Radiative Forcing of Climate Change. Space Sci Rev 94:363-373. doi:10.1023/A:1026752230256

Springmann M, Clark M, Mason-D’Croz D, Wiebe K, Bodirsky BL, Lassaletta L, de Vries W, Vermeulen SJ, Herrero M, Carlson KM, Jonell M, Troell M, DeClerck F, Gordon LJ, Zurayk R, Scarborough P, Rayner M, Loken B, Fanzo J, Godfray HCJ, Tilman D, Rockström J, Willett W. 2018a. Options for keeping the food system within environmental limits. Nature 562:519-525. doi:10.1038/s41586-018-0594-0

Springmann M, Godfray HCJ, Rayner M, Scarborough P. 2016. Analysis and valuation of the health and climate change cobenefits of dietary change. Proc Natl Acad Sci U S A 113:4146-4151. doi:10.1073/pnas.1523119113

Springmann M, Wiebe K, Mason-D’Croz D, Sulser TB, Rayner M, Scarborough P. 2018b. Health 
and nutritional aspects of sustainable diet strategies and their association with environmental impacts: a global modelling analysis with country-level detail. Lancet Planet Health 2:e451-e461. doi:10.1016/S2542-5196(18)30206-7

Stehfest E, van Zeist W-J, Valin H, Havlik P, Popp A, Kyle P, Tabeau A, Mason-D'Croz D, Hasegawa T, Bodirsky BL, Calvin K, Doelman JC, Fujimori S, Humpenöder F, Lotze-Campen $\mathrm{H}$, van Meijl H, Wiebe K. 2019. Key determinants of global land-use projections. Nat Commun 10:2166. doi:10.1038/s41467-019-09945-w

Steinfeld H, Gerber P, Wassenaar T, Castel V, Rosales M, de Haan C. 2006. Livestock's Long Shadow. Food and Agriculture Organization. http://www.fao.org/docrep/010/a0701e/a0701e.pdf

Strassburg BBN, Iribarrem A, Beyer HL, Cordeiro CL, Crouzeilles R, Jakovac CC, Braga Junqueira A, Lacerda $E$, Latawiec AE, Balmford A, Brooks TM, Butchart SHM, Chazdon RL, Erb K-H, Brancalion P, Buchanan G, Cooper D, Díaz S, Donald PF, Kapos V, Leclère D, Miles L, Obersteiner M, Plutzar C, de M Scaramuzza CA, Scarano FR, Visconti P. 2020. Global priority areas for ecosystem restoration. Nature 586:724-729. doi:10.1038/s41586-020-2784-9

Tilman D, Clark M. 2014. Global diets link environmental sustainability and human health. Nature 515:518-522. doi:10.1038/nature13959

Twine R. 2021. Emissions from Animal Agriculture-16.5\% Is the New Minimum Figure. Sustain Sci Pract Policy 13:6276. doi:10.3390/su13116276

Vågsholm I, Arzoomand NS, Boqvist S. 2020. Food Security, Safety, and Sustainability—Getting the Trade-Offs Right. Frontiers in Sustainable Food Systems 4:16. doi:10.3389/fsufs.2020.00016

van Vuuren DP, Edmonds J, Kainuma M, Riahi K, Thomson A, Hibbard K, Hurtt GC, Kram T, Krey V, Lamarque J-F, Masui T, Meinshausen M, Nakicenovic N, Smith SJ, Rose SK. 2011. The representative concentration pathways: an overview. Clim Change 109:5. doi:10.1007/s10584-011-0148-z

Walker JCG. 1977. Evolution of the atmosphere. New York: Macmillan.

Willett W, Rockström J, Loken B, Springmann M, Lang T, Vermeulen S, Garnett T, Tilman D, DeClerck F, Wood A, Jonell M, Clark M, Gordon LJ, Fanzo J, Hawkes C, Zurayk R, Rivera JA, De Vries W, Majele Sibanda L, Afshin A, Chaudhary A, Herrero M, Agustina R, Branca F, Lartey A, Fan S, Crona B, Fox E, Bignet V, Troell M, Lindahl T, Singh S, Cornell SE, Srinath Reddy K, Narain S, Nishtar S, Murray CJL. 2019. Food in the Anthropocene: the EAT-Lancet Commission on healthy diets from sustainable food systems. Lancet 393:447-492. doi:10.1016/S0140-6736(18)31788-4

World Wildlife Fund. 2020. Living Planet Report 2020.

Xu X, Sharma P, Shu S, Lin T-S, Ciais P, Tubiello FN, Smith P, Campbell N, Jain AK. 2021. Global greenhouse gas emissions from animal-based foods are twice those of plant-based foods. Nature Food 2:724-732. doi:10.1038/s43016-021-00358-x 
bioRxiv preprint doi: https://doi.org/10.1101/2021.04.15.440019; this version posted October 12, 2021. The copyright holder for this preprint (which was not certified by peer review) is the author/funder, who has granted bioRxiv a license to display the preprint in perpetuity. It is made available under aCC-BY 4.0 International license.

A

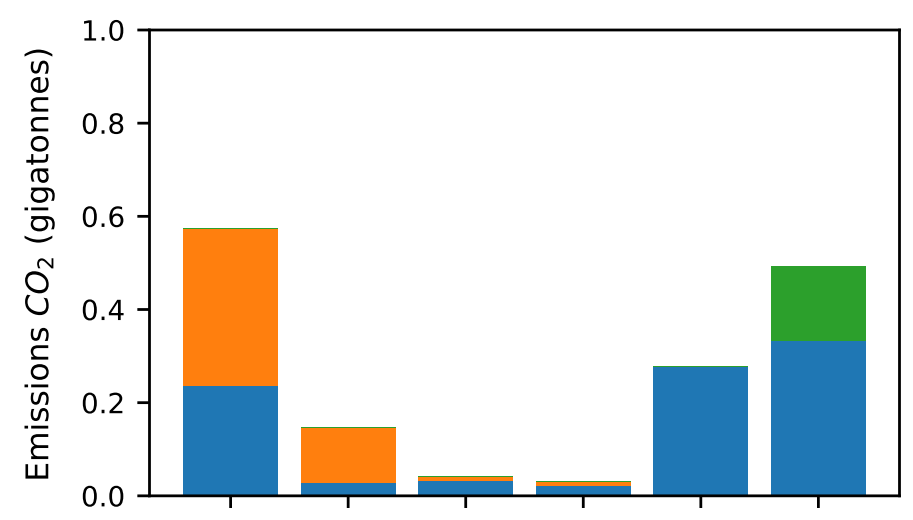

Meat

Milk

Eggs

B

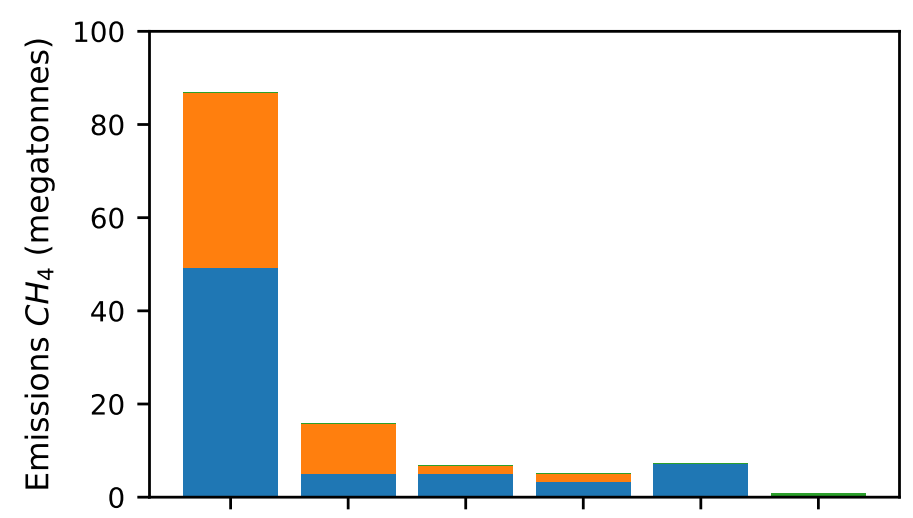

Meat

Milk

Eggs

C

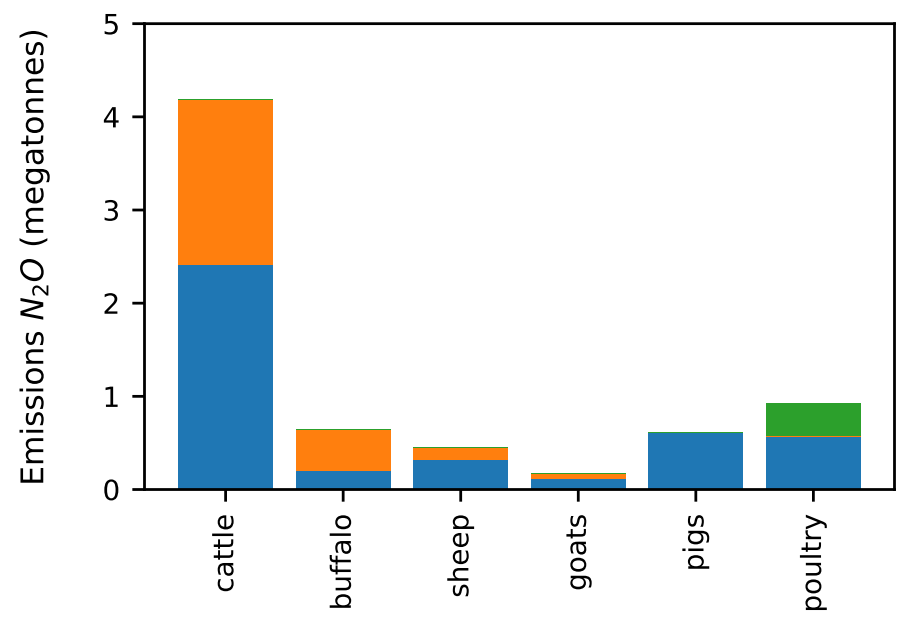

Meat

Milk

Eggs

Figure 1-S1. Gas-specific emission footprints of animal agriculture.

Assembled from species, product and country-specific production data from FAOSTAT for 2018 and species, product, region and greenhouse gas-specific emissions data from GLEAM (MacLeod et al., 2018). 
bioRxiv preprint doi: https://doi.org/10.1101/2021.04.15.440019; this version posted October 12, 2021. The copyright holder for this preprint (which was not certified by peer review) is the author/funder, who has granted bioRxiv a license to display the preprint in perpetuity. It is made available under aCC-BY 4.0 International license.

\section{A}

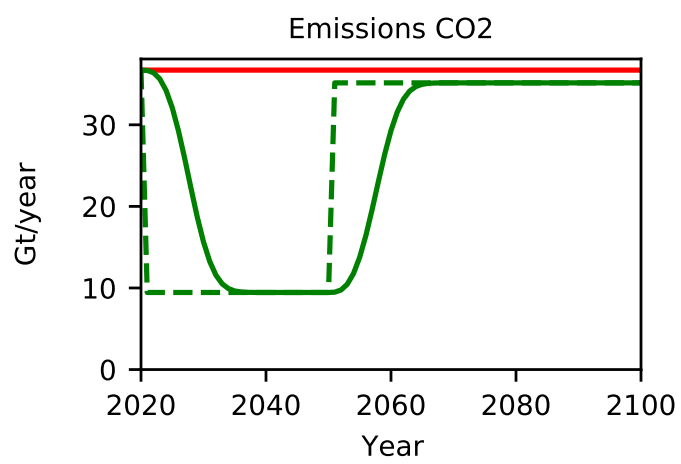

Emissions $\mathrm{CH} 4$

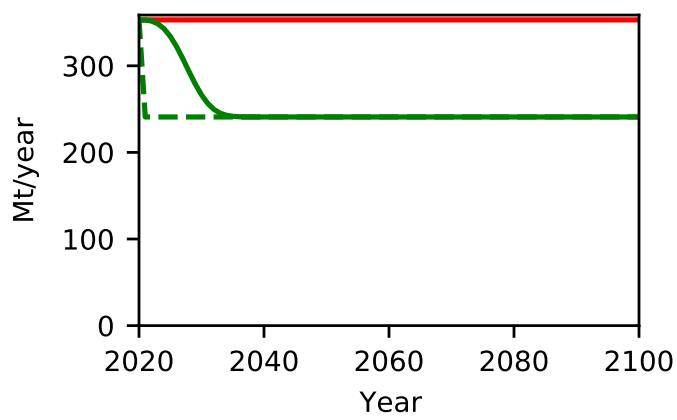

Emissions N2O

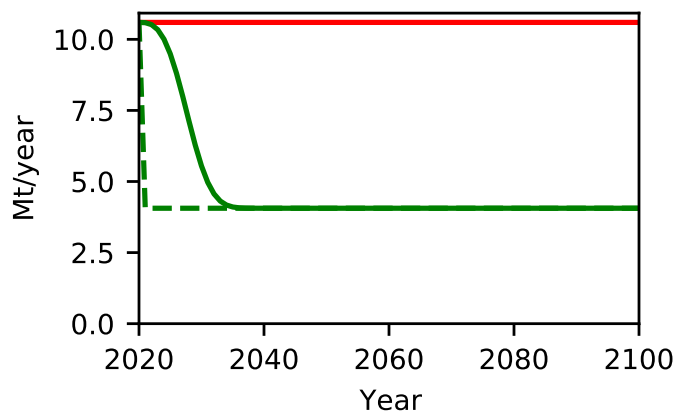

Business as Usual
IMM-POD
PHASE-POD (Default)
B
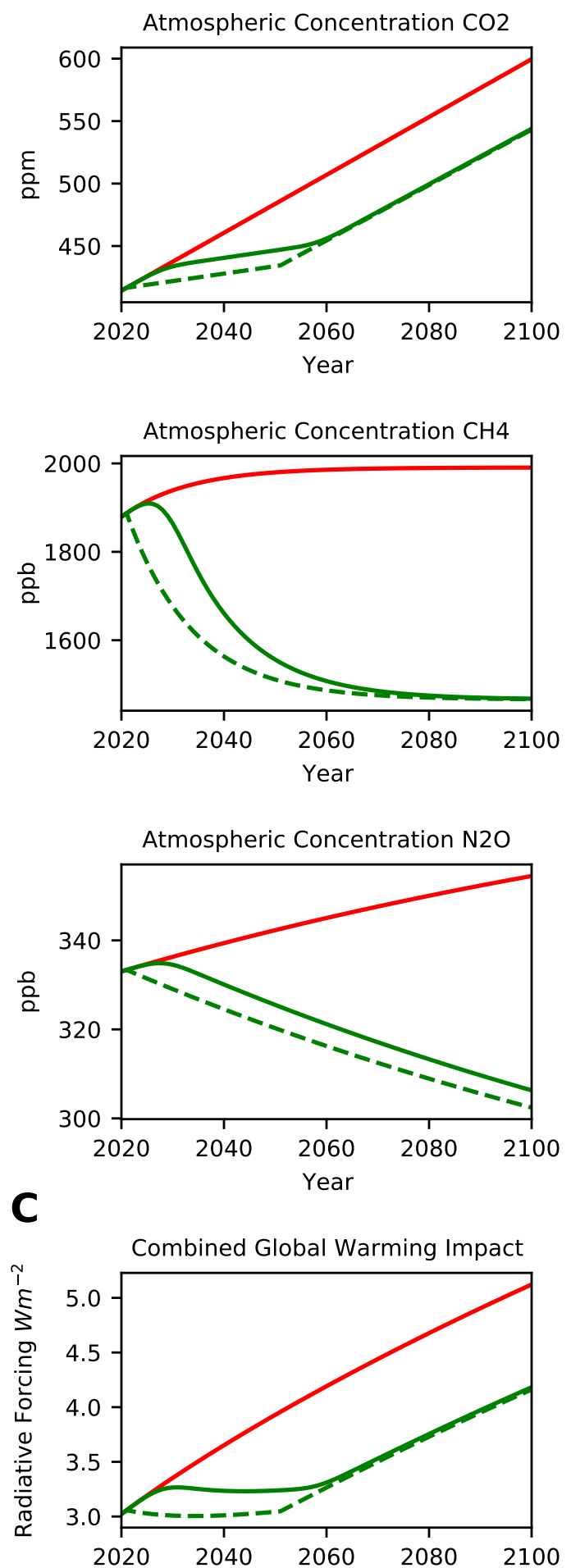

Figure 2-S1. 15yr Phaseout vs. Elimination.

(A) Projected annual emissions of $\mathrm{CO}_{2}, \mathrm{CH}_{4}$ and $\mathrm{N}_{2} \mathrm{O}$ for each scenarios. (B) Projected atmospheric concentrations of $\mathrm{CO}_{2}, \mathrm{CH}_{4}$ and $\mathrm{N}_{2} \mathrm{O}$ under each emission scenario. (C)

Radiative Forcing (RF) inferred from atmospheric concentrations in (B) by formula of (Myhre et al., 1998; Ramaswamy et al., 2001) as modified in MAGICC6 (Meinshausen et al., 2011). Only differences between PHASE-POD default assumptions (15yr phaseout, 30yr carbon recovery, 100\% carbon recovery, BAU non-agriculture emissions, FAO crop replacement, and FAO animal ag emissions) are given. 
bioRxiv preprint doi: https://doi.org/10.1101/2021.04.15.440019; this version posted October 12, 2021. The copyright holder for this preprint (which was not certified by peer review) is the author/funder, who has granted bioRxiv a license to display the preprint in perpetuity. It is made available under aCC-BY 4.0 International license.

\section{A}

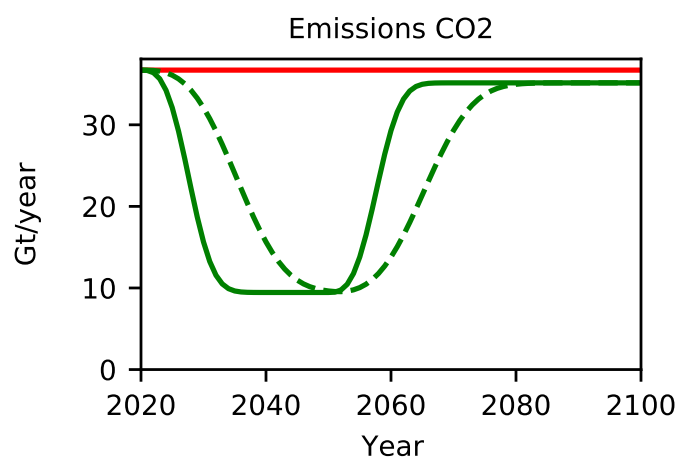

Emissions $\mathrm{CH} 4$

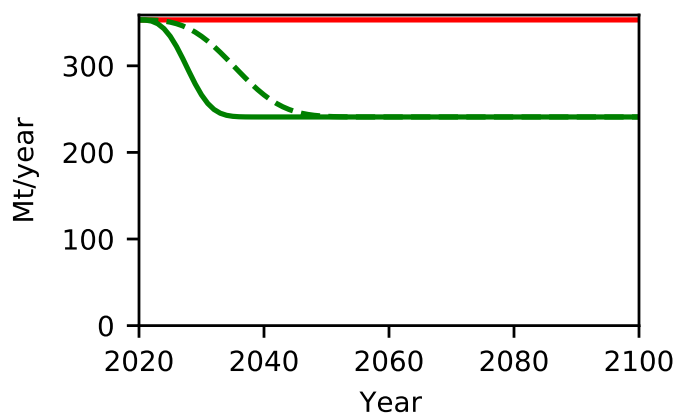

Emissions $\mathrm{N} 2 \mathrm{O}$

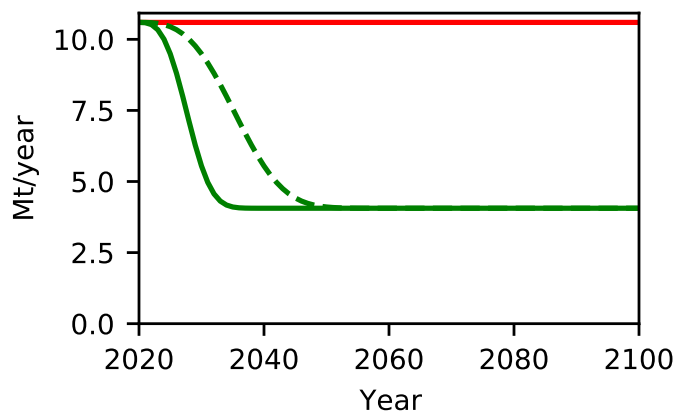

Business as Usual

- 30yr Phaseout

_ PHASE-POD (Default)
B
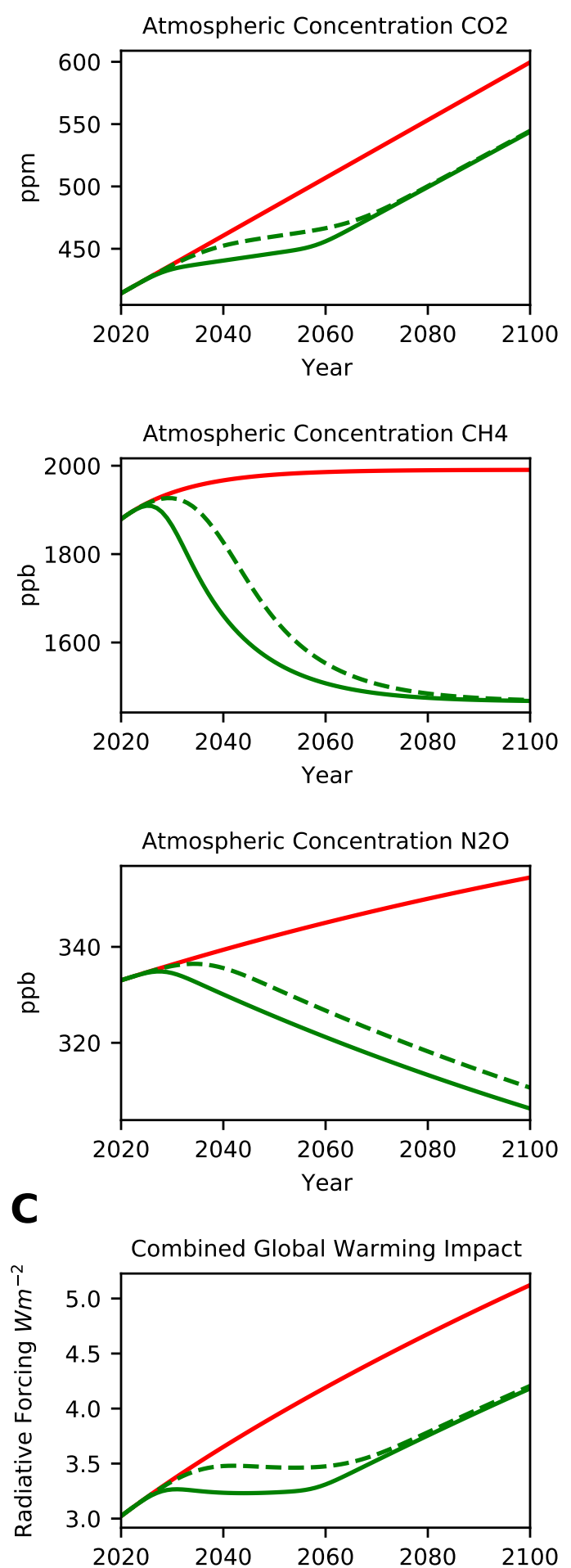

Figure 2-S2. 15yr vs. 30yr Phaseout.

(A) Projected annual emissions of $\mathrm{CO}_{2}, \mathrm{CH}_{4}$ and $\mathrm{N}_{2} \mathrm{O}$ for each scenarios. (B) Projected atmospheric concentrations of $\mathrm{CO}_{2}, \mathrm{CH}_{4}$ and $\mathrm{N}_{2} \mathrm{O}$ under each emission scenario. (C)

Radiative Forcing (RF) inferred from atmospheric concentrations in (B) by formula of (Myhre et al., 1998; Ramaswamy et al., 2001) as modified in MAGICC6 (Meinshausen et al., 2011). Only differences between PHASE-POD default assumptions (15yr phaseout, 30yr carbon recovery, 100\% carbon recovery, BAU non-agriculture emissions, FAO crop replacement, and FAO animal ag emissions) are given. 
bioRxiv preprint doi: https://doi.org/10.1101/2021.04.15.440019; this version posted October 12, 2021. The copyright holder for this preprint (which was not certified by peer review) is the author/funder, who has granted bioRxiv a license to display the preprint in perpetuity. It is made available under aCC-BY 4.0 International license.

\section{A}
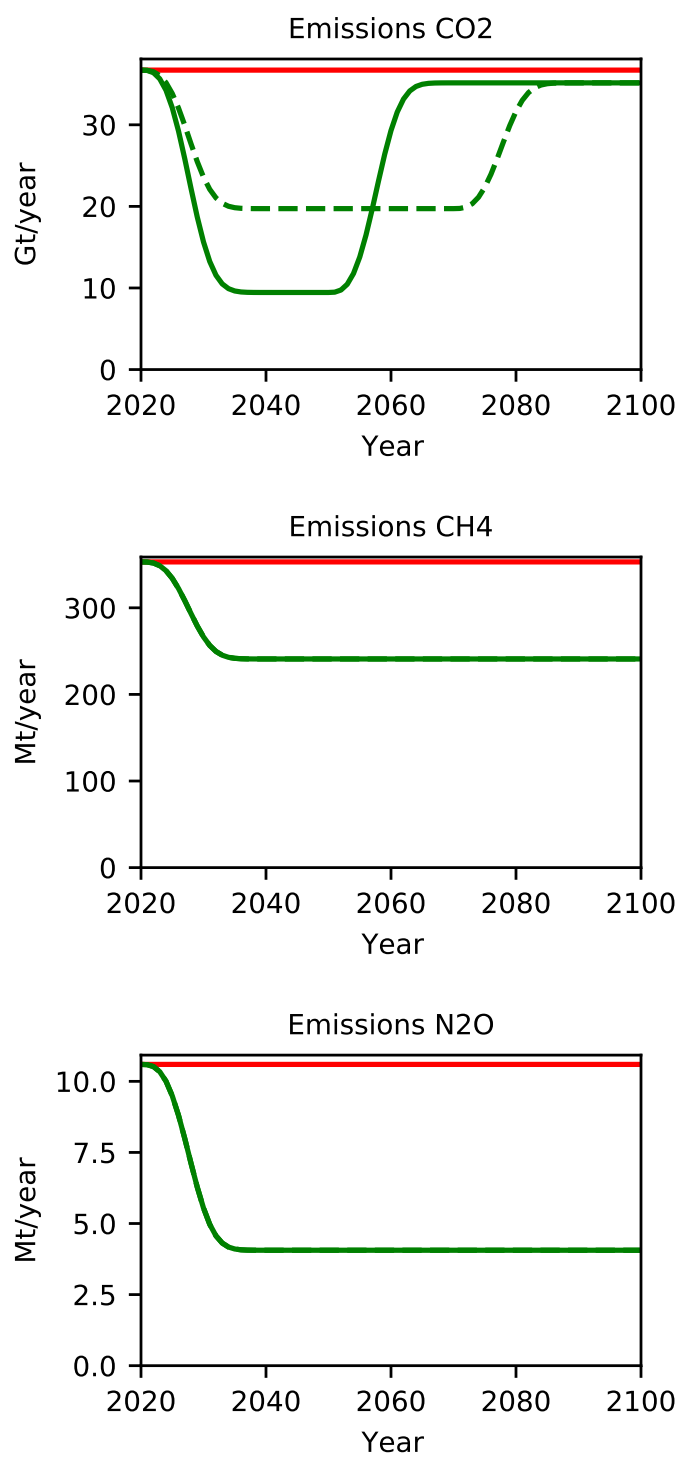

B
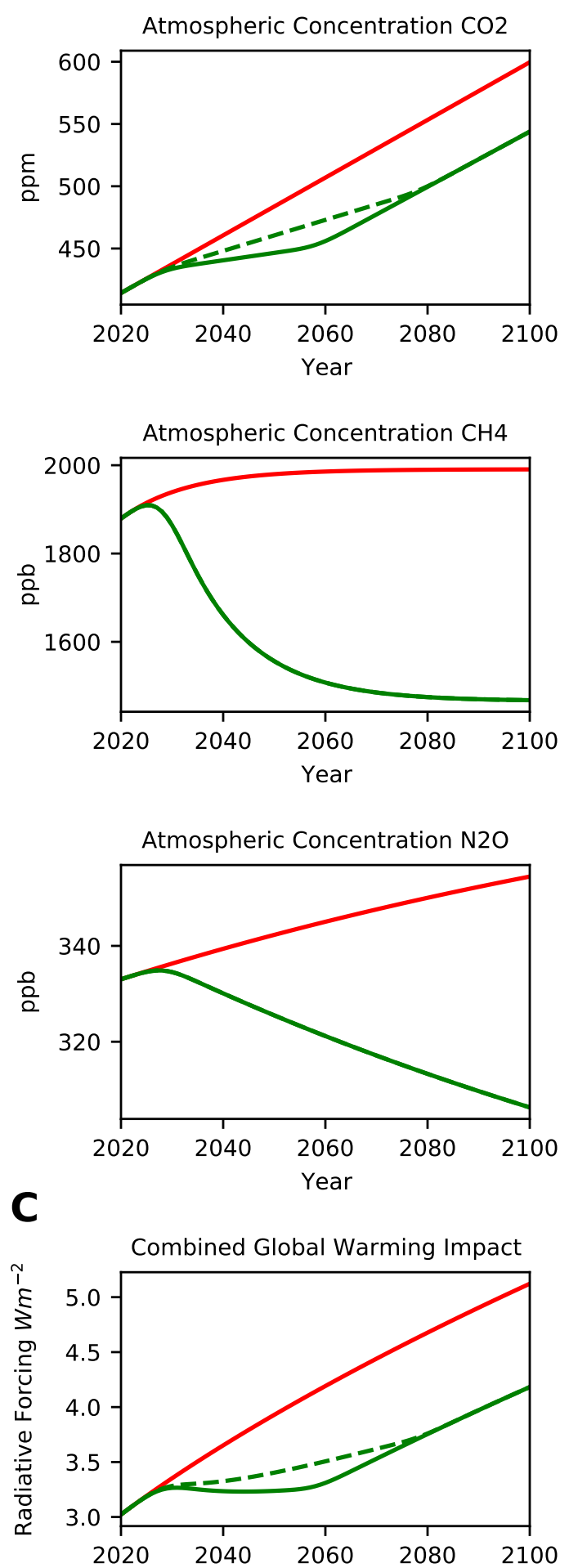

Figure 2-S3. 30yr vs. 50yr Biomass Recovery.

(A) Projected annual emissions of $\mathrm{CO}_{2}, \mathrm{CH}_{4}$ and $\mathrm{N}_{2} \mathrm{O}$ for each scenarios. (B) Projected atmospheric concentrations of $\mathrm{CO}_{2}, \mathrm{CH}_{4}$ and $\mathrm{N}_{2} \mathrm{O}$ under each emission scenario. (C)

Radiative Forcing (RF) inferred from atmospheric concentrations in (B) by formula of (Myhre et al., 1998; Ramaswamy et al., 2001) as modified in MAGICC6 (Meinshausen et al., 2011). Only differences between PHASE-POD default assumptions (15yr phaseout, 30yr carbon recovery, 100\% carbon recovery, BAU non-agriculture emissions, FAO crop replacement, and FAO animal ag emissions) are given. 
bioRxiv preprint doi: https://doi.org/10.1101/2021.04.15.440019; this version posted October 12, 2021. The copyright holder for this preprint (which was not certified by peer review) is the author/funder, who has granted bioRxiv a license to display the preprint in perpetuity. It is made available under aCC-BY 4.0 International license.

\section{A}
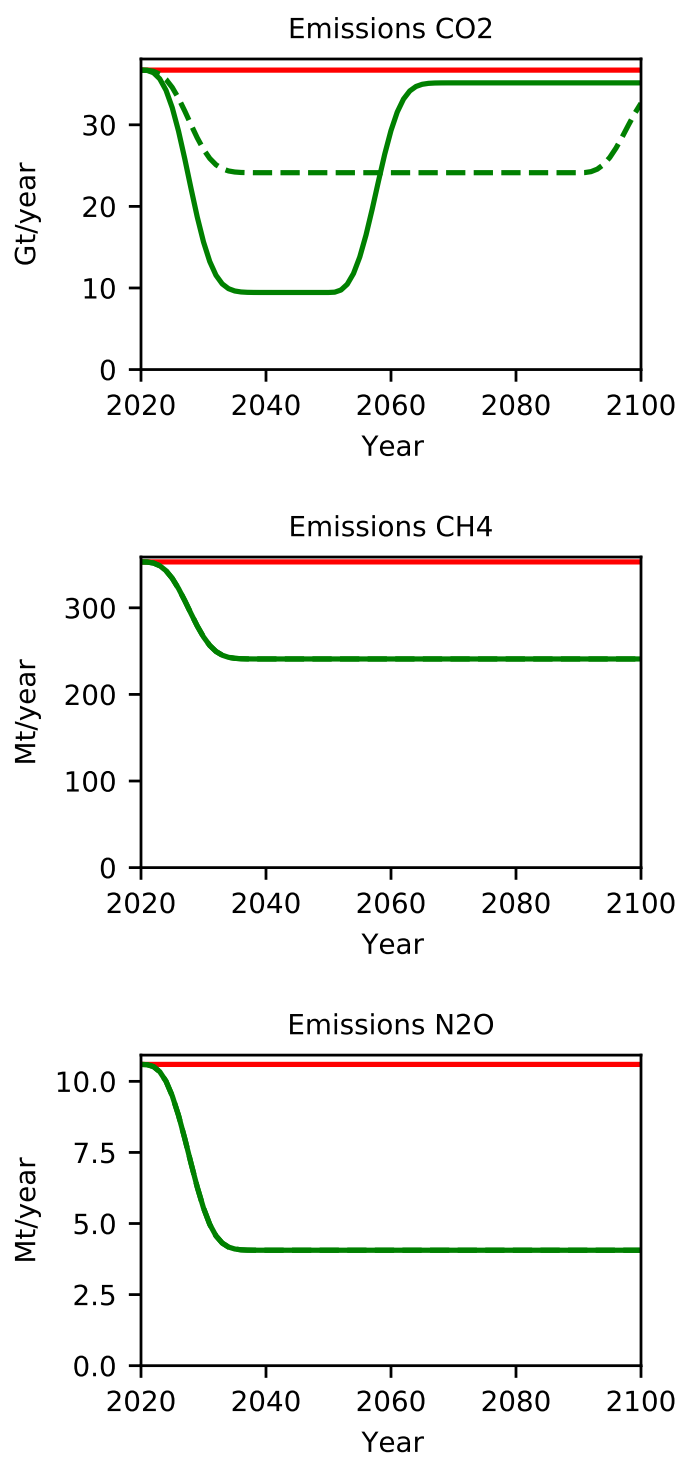

B
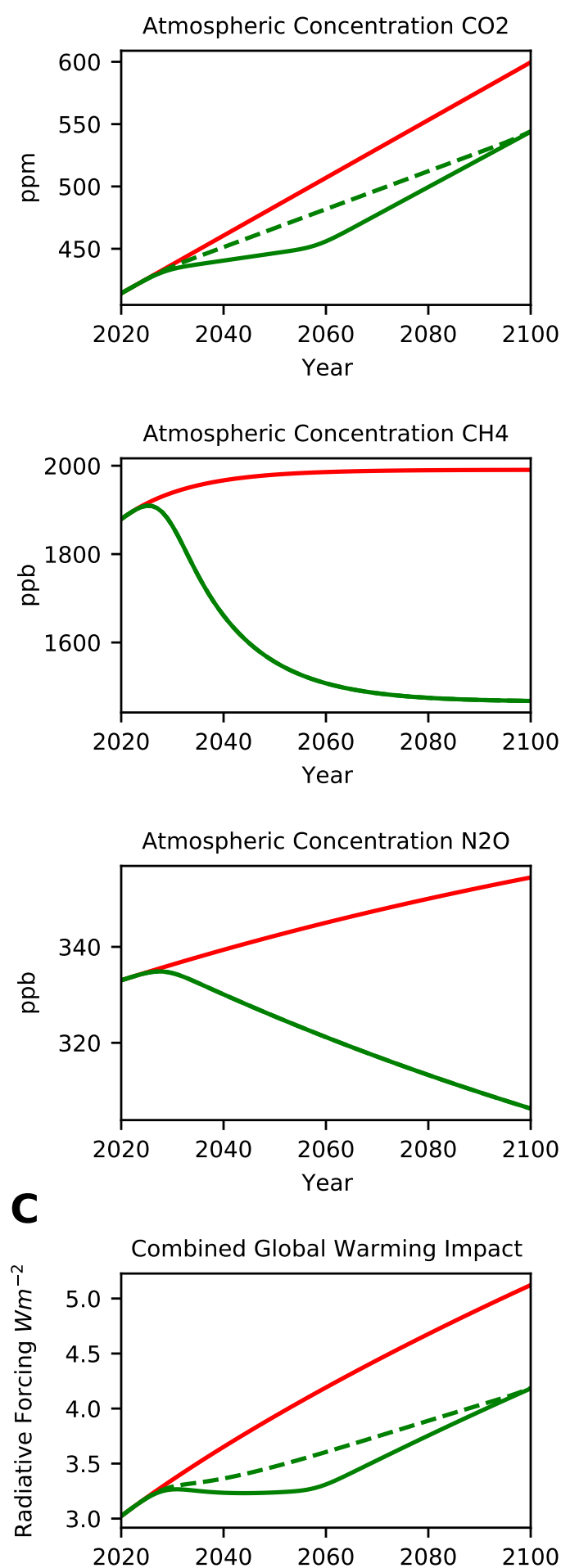

Figure 2-S4. 30yr vs. 70yr Biomass Recovery.

(A) Projected annual emissions of $\mathrm{CO}_{2}, \mathrm{CH}_{4}$ and $\mathrm{N}_{2} \mathrm{O}$ for each scenarios. (B) Projected atmospheric concentrations of $\mathrm{CO}_{2}, \mathrm{CH}_{4}$ and $\mathrm{N}_{2} \mathrm{O}$ under each emission scenario. (C)

Radiative Forcing (RF) inferred from atmospheric concentrations in (B) by formula of (Myhre et al., 1998; Ramaswamy et al., 2001) as modified in MAGICC6 (Meinshausen et al., 2011). Only differences between PHASE-POD default assumptions (15yr phaseout, 30yr carbon recovery, 100\% carbon recovery, BAU non-agriculture emissions, FAO crop replacement, and FAO animal ag emissions) are given. 
bioRxiv preprint doi: https://doi.org/10.1101/2021.04.15.440019; this version posted October 12, 2021. The copyright holder for this preprint (which was not certified by peer review) is the author/funder, who has granted bioRxiv a license to display the preprint in perpetuity. It is made available under aCC-BY 4.0 International license.

\section{A}
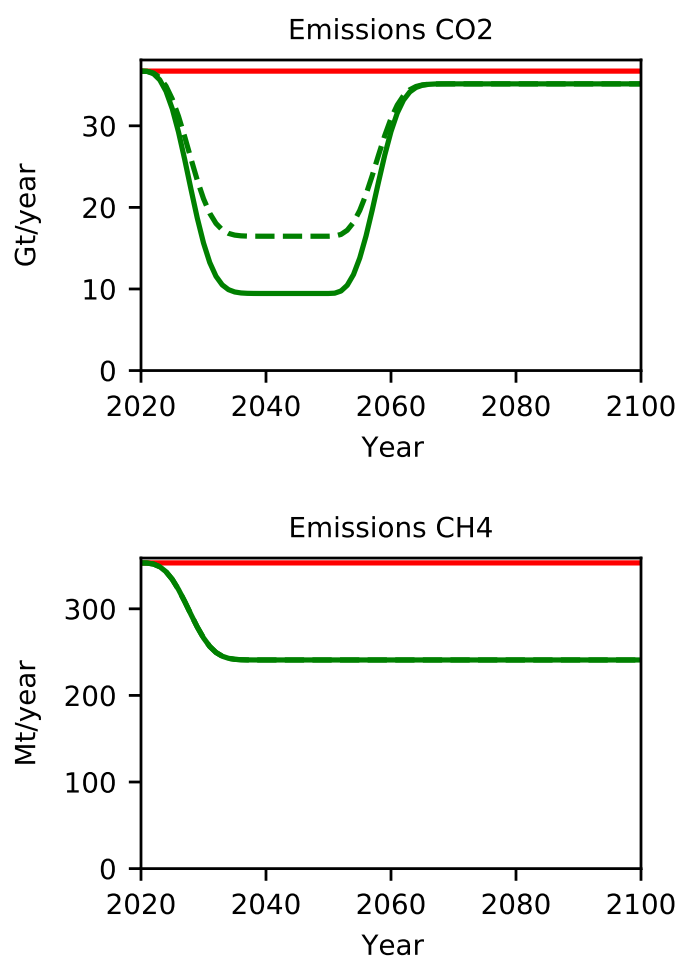

Emissions N2O

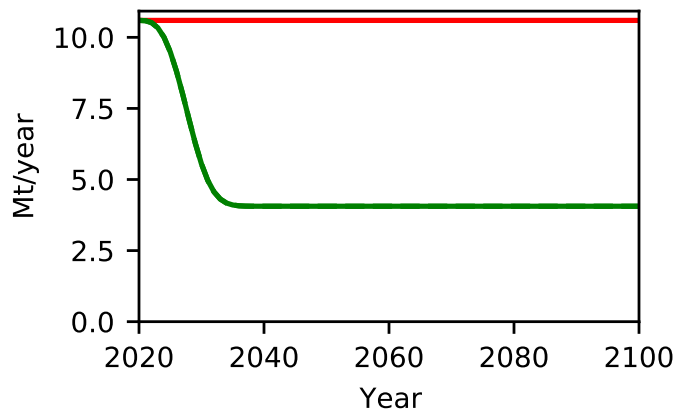

Business as Usual

- Hayak Low Biomass Potential

PHASE-POD (Default)
B
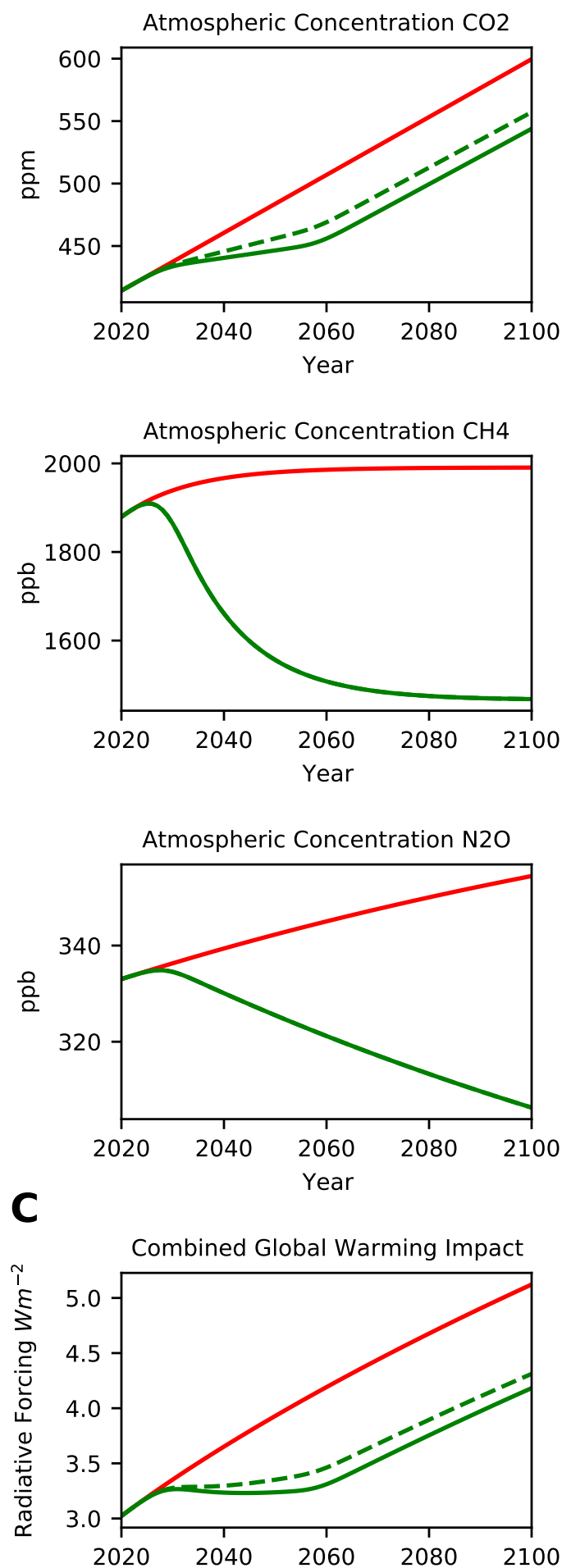

Figure 2-S5. Hayek Median vs. Low Recovery Potential.

(A) Projected annual emissions of $\mathrm{CO}_{2}, \mathrm{CH}_{4}$ and $\mathrm{N}_{2} \mathrm{O}$ for each scenarios. (B) Projected atmospheric concentrations of $\mathrm{CO}_{2}, \mathrm{CH}_{4}$ and $\mathrm{N}_{2} \mathrm{O}$ under each emission scenario. (C)

Radiative Forcing (RF) inferred from atmospheric concentrations in (B) by formula of (Myhre et al., 1998; Ramaswamy et al., 2001) as modified in MAGICC6 (Meinshausen et al., 2011). Only differences between PHASE-POD default assumptions (15yr phaseout, 30yr carbon recovery, 100\% carbon recovery, BAU non-agriculture emissions, FAO crop replacement, and FAO animal ag emissions) are given. 
bioRxiv preprint doi: https://doi.org/10.1101/2021.04.15.440019; this version posted October 12, 2021. The copyright holder for this preprint (which was not certified by peer review) is the author/funder, who has granted bioRxiv a license to display the preprint in perpetuity. It is made available under aCC-BY 4.0 International license.

A

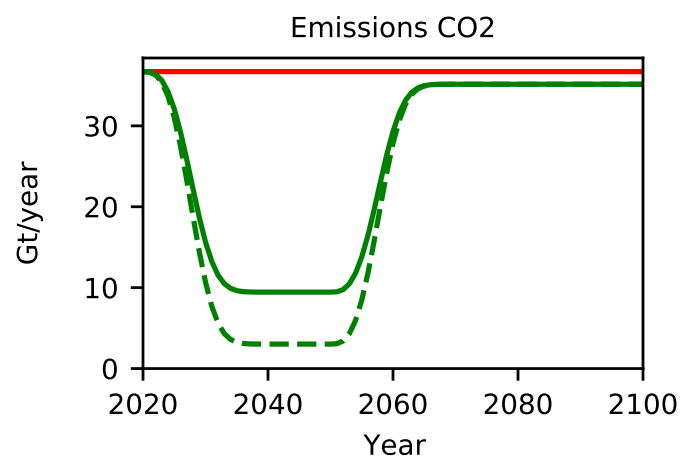

Emissions $\mathrm{CH} 4$

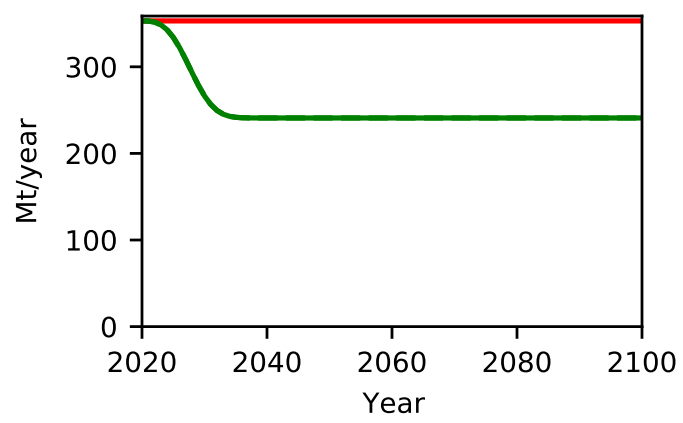

Emissions N2O

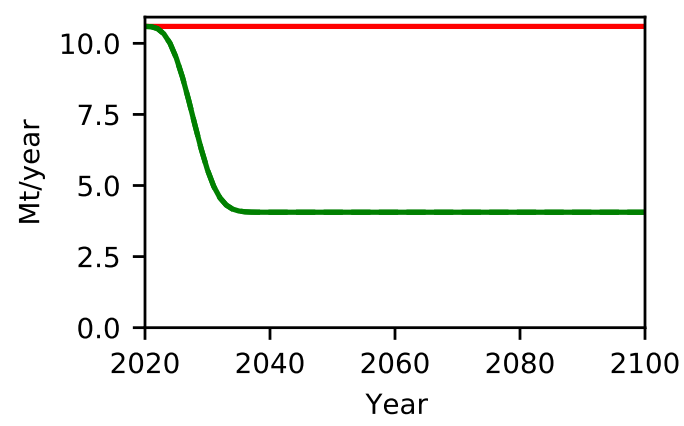

B
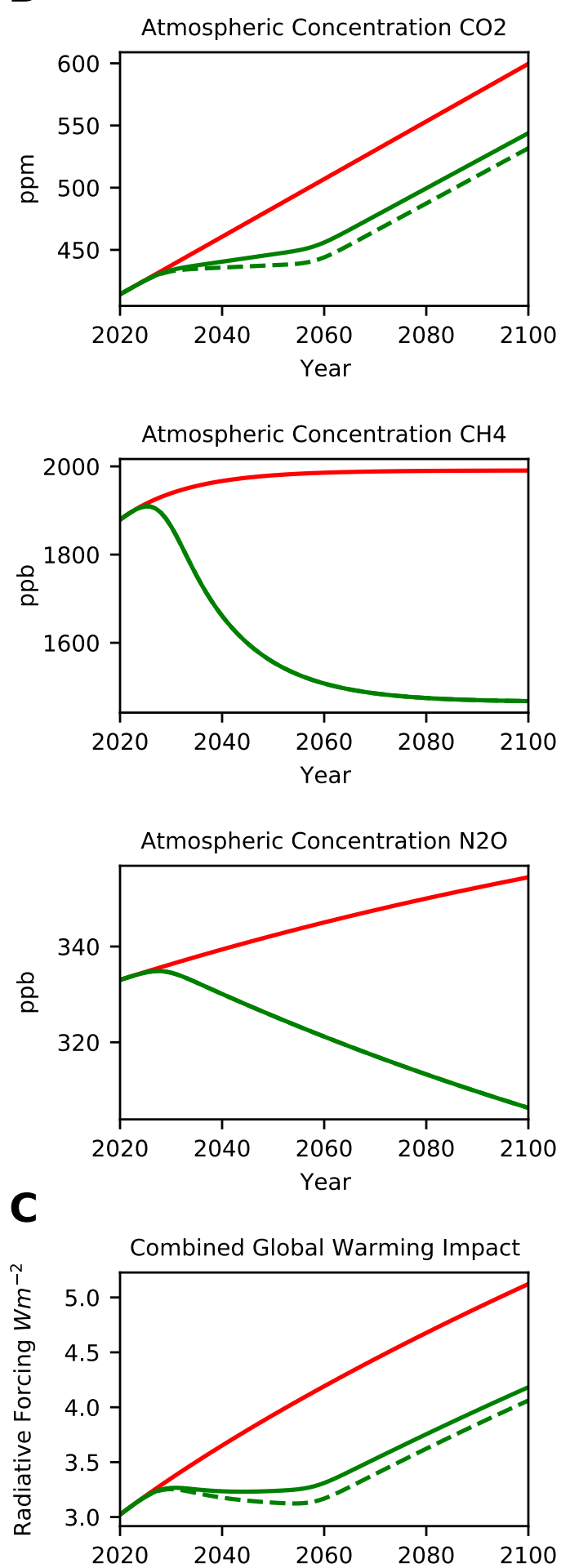

Figure 2-S6. Hayek Median vs. High Recovery Potential.

(A) Projected annual emissions of $\mathrm{CO}_{2}, \mathrm{CH}_{4}$ and $\mathrm{N}_{2} \mathrm{O}$ for each scenarios. (B) Projected atmospheric concentrations of $\mathrm{CO}_{2}, \mathrm{CH}_{4}$ and $\mathrm{N}_{2} \mathrm{O}$ under each emission scenario. (C)

Radiative Forcing (RF) inferred from atmospheric concentrations in (B) by formula of (Myhre et al., 1998; Ramaswamy et al., 2001) as modified in MAGICC6 (Meinshausen et al., 2011). Only differences between PHASE-POD default assumptions (15yr phaseout, 30yr carbon recovery, 100\% carbon recovery, BAU non-agriculture emissions, FAO crop replacement, and FAO animal ag emissions) are given. 
bioRxiv preprint doi: https://doi.org/10.1101/2021.04.15.440019; this version posted October 12, 2021. The copyright holder for this preprint (which was not certified by peer review) is the author/funder, who has granted bioRxiv a license to display the preprint in perpetuity. It is made available under aCC-BY 4.0 International license.

\section{A}
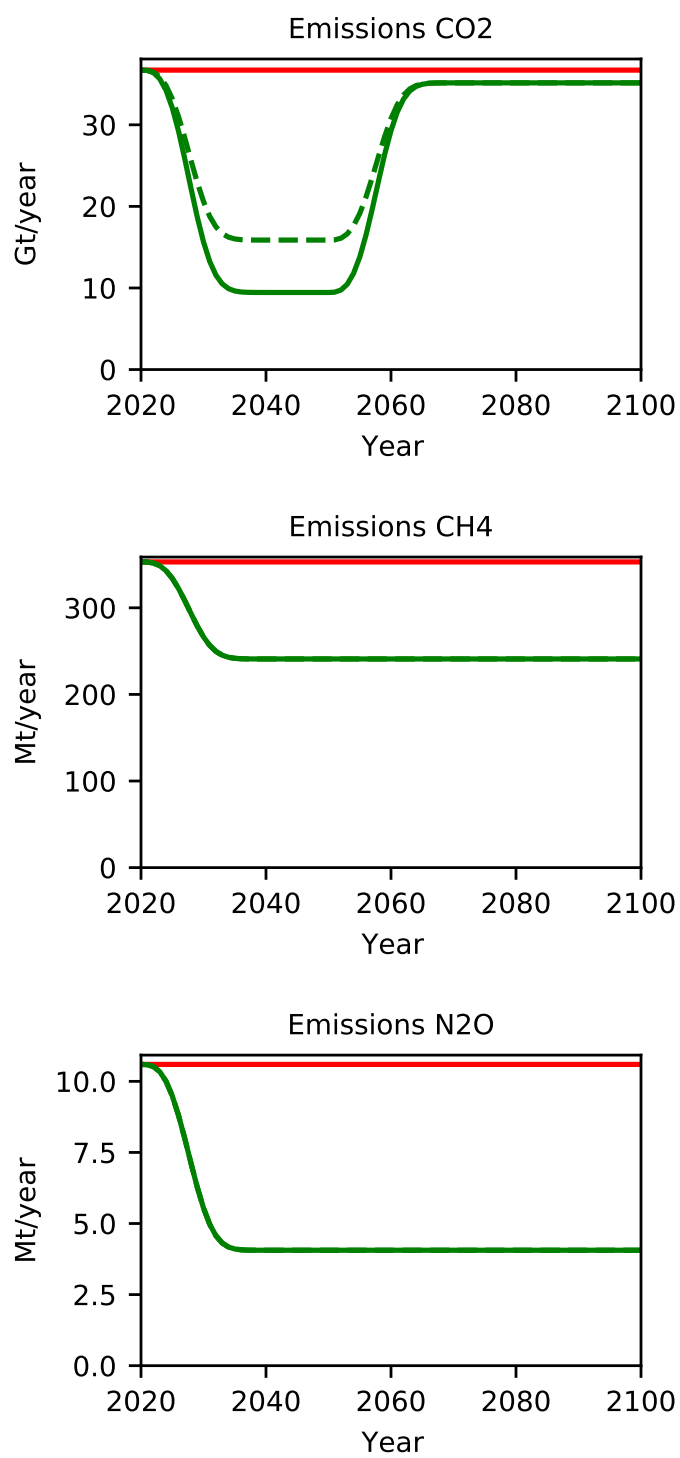

B
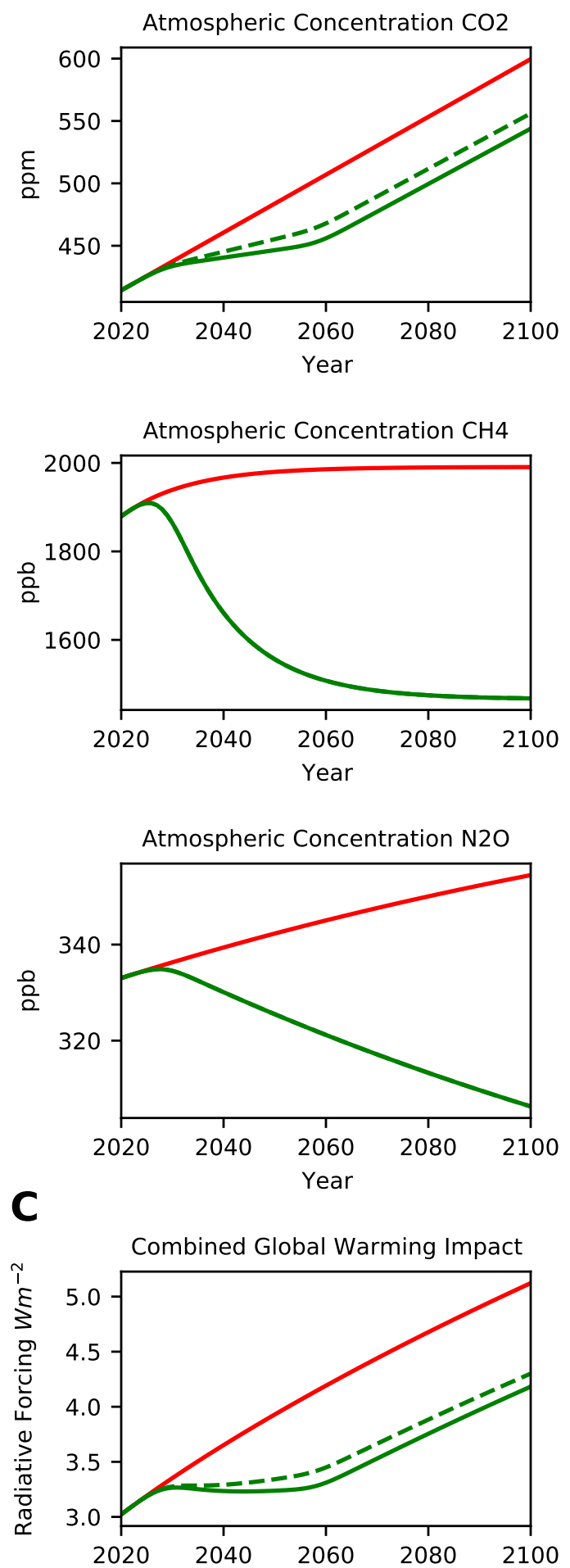

Figure 2-S7. $100 \%$ vs. $75 \%$ Biomass Recovery.

(A) Projected annual emissions of $\mathrm{CO}_{2}, \mathrm{CH}_{4}$ and $\mathrm{N}_{2} \mathrm{O}$ for each scenarios. (B) Projected atmospheric concentrations of $\mathrm{CO}_{2}, \mathrm{CH}_{4}$ and $\mathrm{N}_{2} \mathrm{O}$ under each emission scenario. (C)

Radiative Forcing (RF) inferred from atmospheric concentrations in (B) by formula of (Myhre et al., 1998; Ramaswamy et al., 2001) as modified in MAGICC6 (Meinshausen et al., 2011). Only differences between PHASE-POD default assumptions (15yr phaseout, 30yr carbon recovery, 100\% carbon recovery, BAU non-agriculture emissions, FAO crop replacement, and FAO animal ag emissions) are given. 
bioRxiv preprint doi: https://doi.org/10.1101/2021.04.15.440019; this version posted October 12, 2021. The copyright holder for this preprint (which was not certified by peer review) is the author/funder, who has granted bioRxiv a license to display the preprint in perpetuity. It is made available under aCC-BY 4.0 International license.

\section{A}
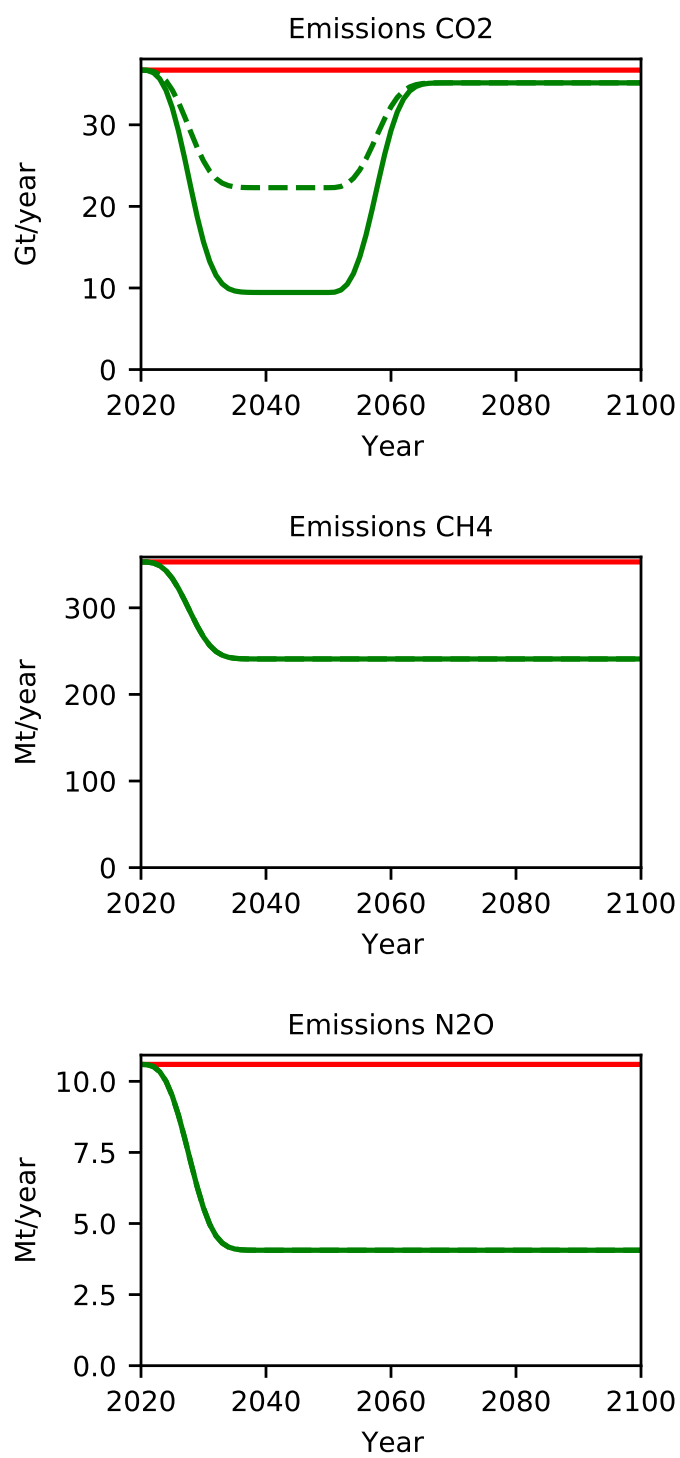

B
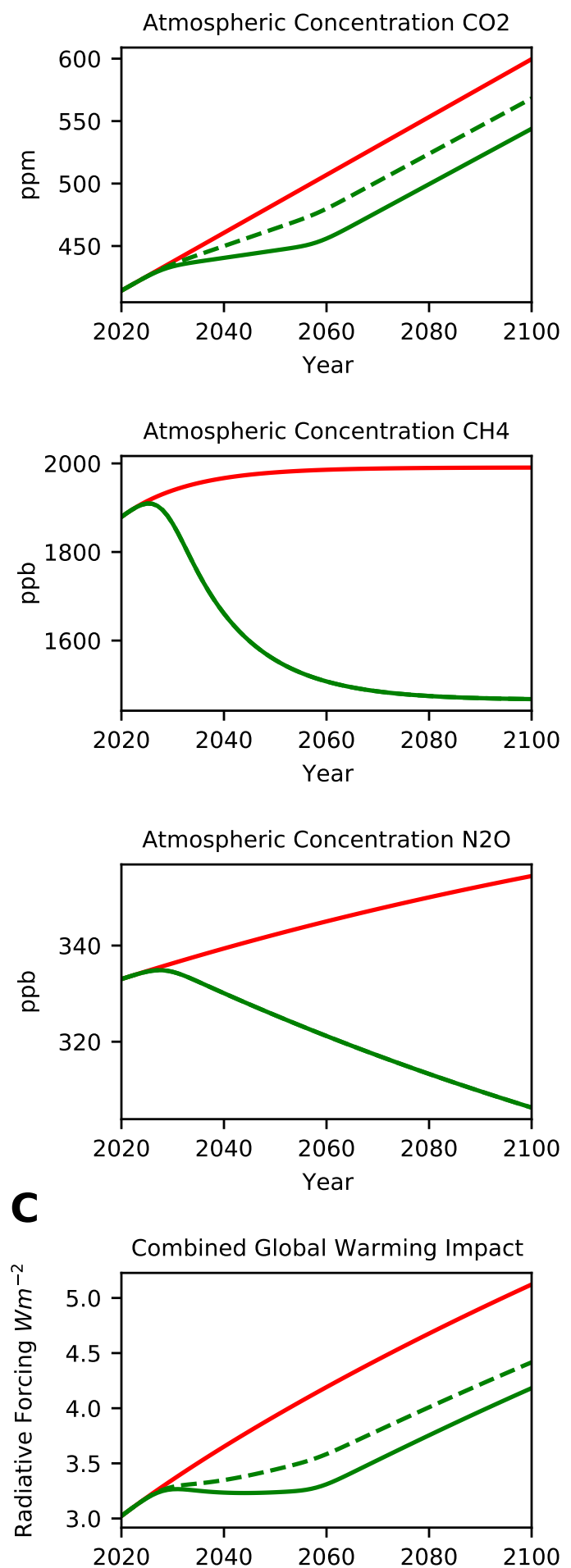

Figure 2-S8. $100 \%$ vs. $50 \%$ Biomass Recovery.

(A) Projected annual emissions of $\mathrm{CO}_{2}, \mathrm{CH}_{4}$ and $\mathrm{N}_{2} \mathrm{O}$ for each scenarios. (B) Projected atmospheric concentrations of $\mathrm{CO}_{2}, \mathrm{CH}_{4}$ and $\mathrm{N}_{2} \mathrm{O}$ under each emission scenario. (C)

Radiative Forcing (RF) inferred from atmospheric concentrations in (B) by formula of (Myhre et al., 1998; Ramaswamy et al., 2001) as modified in MAGICC6 (Meinshausen et al., 2011). Only differences between PHASE-POD default assumptions (15yr phaseout, 30yr carbon recovery, 100\% carbon recovery, BAU non-agriculture emissions, FAO crop replacement, and FAO animal ag emissions) are given. 
bioRxiv preprint doi: https://doi.org/10.1101/2021.04.15.440019; this version posted October 12, 2021. The copyright holder for this preprint (which was not certified by peer review) is the author/funder, who has granted bioRxiv a license to display the preprint in perpetuity. It is made available under aCC-BY 4.0 International license.

\section{A}
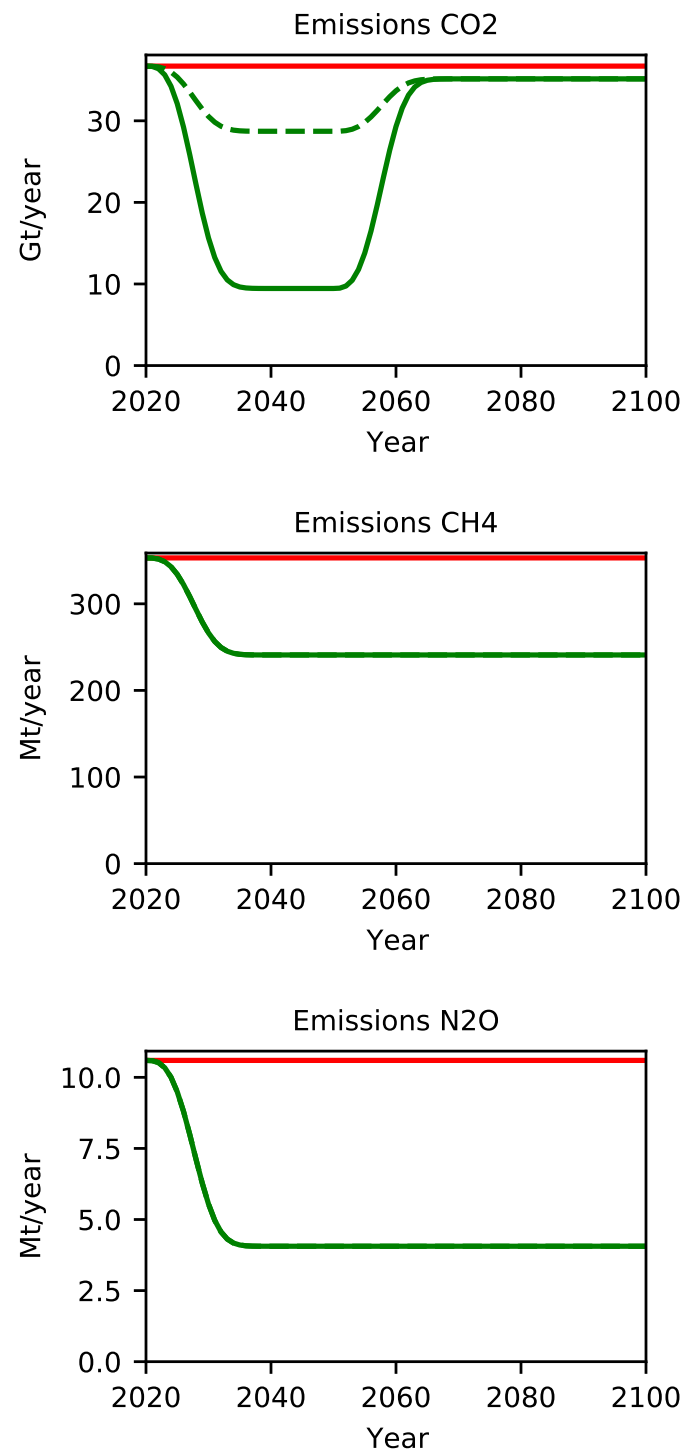

B
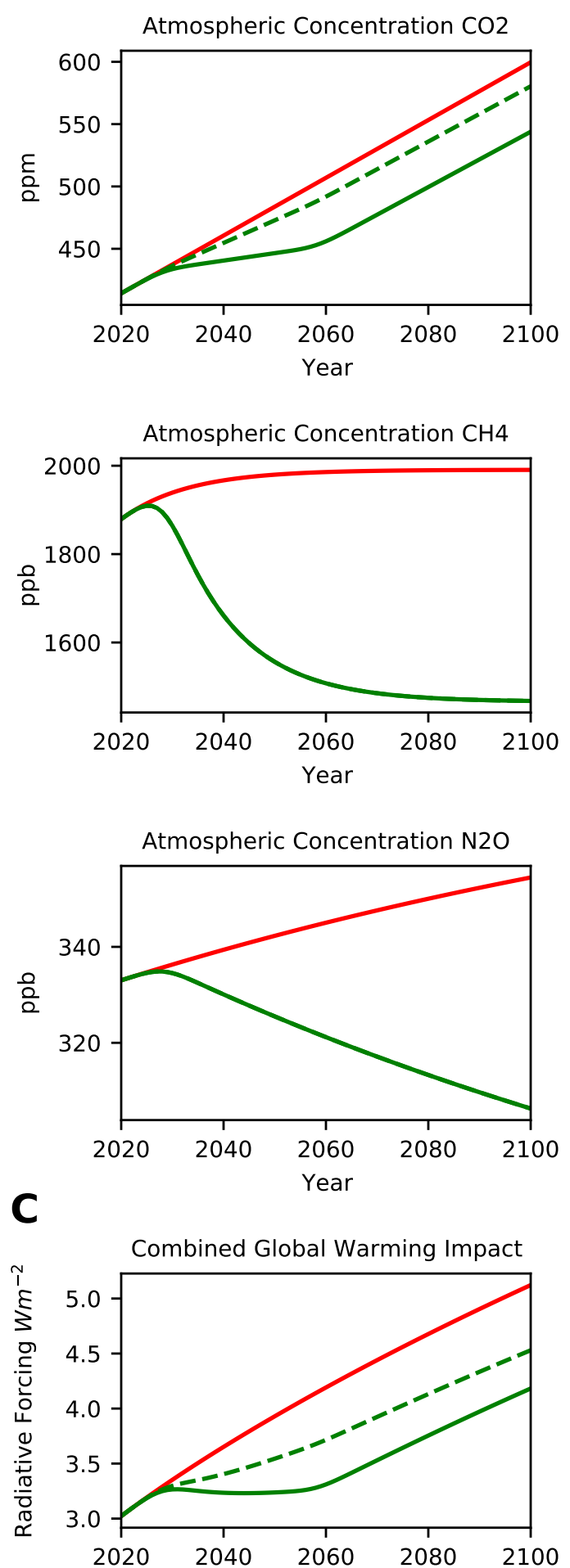

Figure 2-S9. $100 \%$ vs. $25 \%$ Biomass Recovery.

(A) Projected annual emissions of $\mathrm{CO}_{2}, \mathrm{CH}_{4}$ and $\mathrm{N}_{2} \mathrm{O}$ for each scenarios. (B) Projected atmospheric concentrations of $\mathrm{CO}_{2}, \mathrm{CH}_{4}$ and $\mathrm{N}_{2} \mathrm{O}$ under each emission scenario. (C)

Radiative Forcing (RF) inferred from atmospheric concentrations in (B) by formula of (Myhre et al., 1998; Ramaswamy et al., 2001) as modified in MAGICC6 (Meinshausen et al., 2011). Only differences between PHASE-POD default assumptions (15yr phaseout, 30yr carbon recovery, 100\% carbon recovery, BAU non-agriculture emissions, FAO crop replacement, and FAO animal ag emissions) are given. 
bioRxiv preprint doi: https://doi.org/10.1101/2021.04.15.440019; this version posted October 12, 2021. The copyright holder for this preprint (which was not certified by peer review) is the author/funder, who has granted bioRxiv a license to display the preprint in perpetuity. It is made available under aCC-BY 4.0 International license.

\section{A}
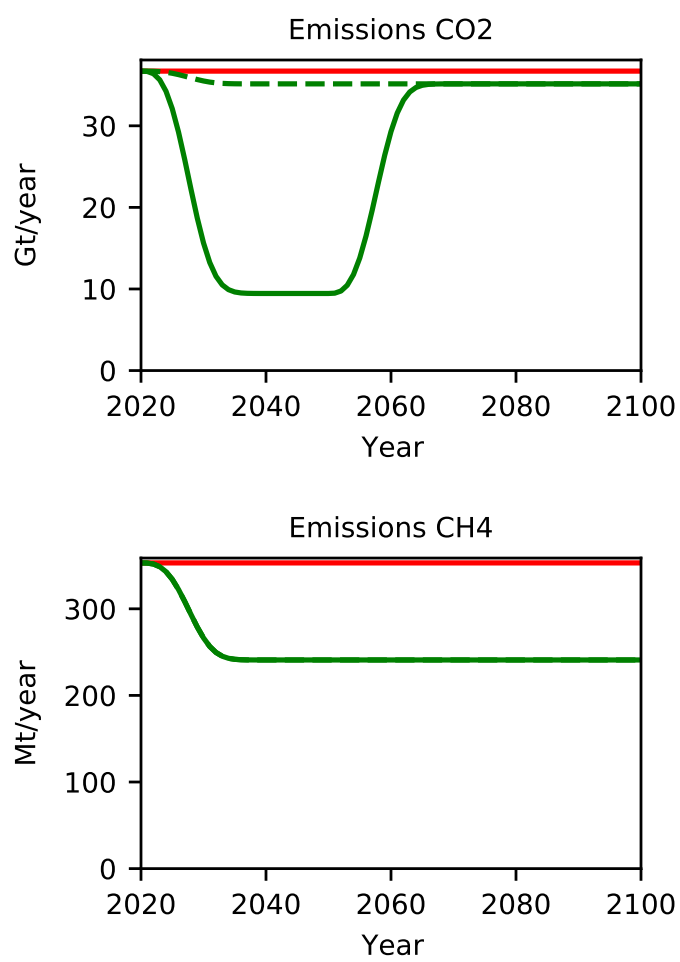

Emissions N2O

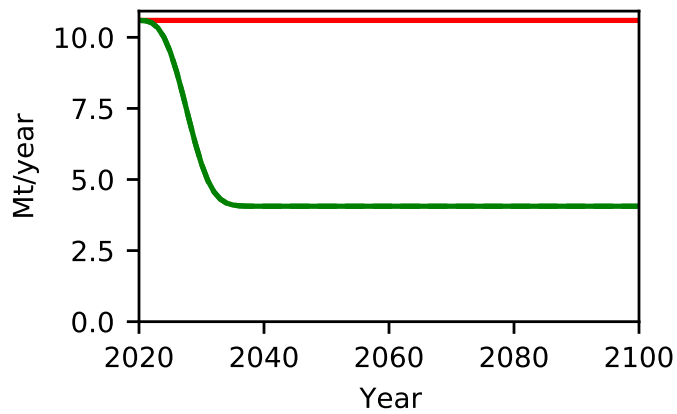

Business as Usual

- $0 \%$ Biomass Recovery

PHASE-POD (Default)
B
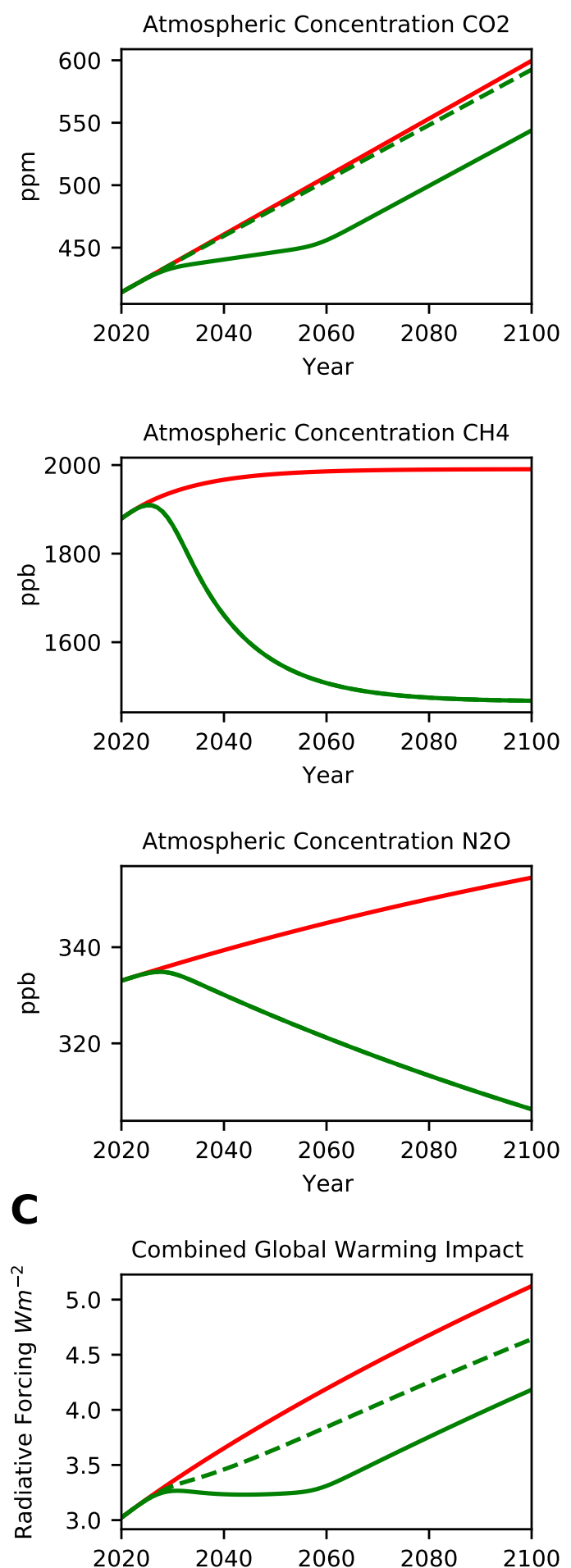

Figure 2-S10. $100 \%$ vs. 0\% Biomass Recovery.

(A) Projected annual emissions of $\mathrm{CO}_{2}, \mathrm{CH}_{4}$ and $\mathrm{N}_{2} \mathrm{O}$ for each scenarios. (B) Projected atmospheric concentrations of $\mathrm{CO}_{2}, \mathrm{CH}_{4}$ and $\mathrm{N}_{2} \mathrm{O}$ under each emission scenario. (C)

Radiative Forcing (RF) inferred from atmospheric concentrations in (B) by formula of (Myhre et al., 1998; Ramaswamy et al., 2001) as modified in MAGICC6 (Meinshausen et al., 2011). Only differences between PHASE-POD default assumptions (15yr phaseout, 30yr carbon recovery, 100\% carbon recovery, BAU non-agriculture emissions, FAO crop replacement, and FAO animal ag emissions) are given. 
bioRxiv preprint doi: https://doi.org/10.1101/2021.04.15.440019; this version posted October 12, 2021. The copyright holder for this preprint (which was not certified by peer review) is the author/funder, who has granted bioRxiv a license to display the preprint in perpetuity. It is made available under aCC-BY 4.0 International license.

\section{A}
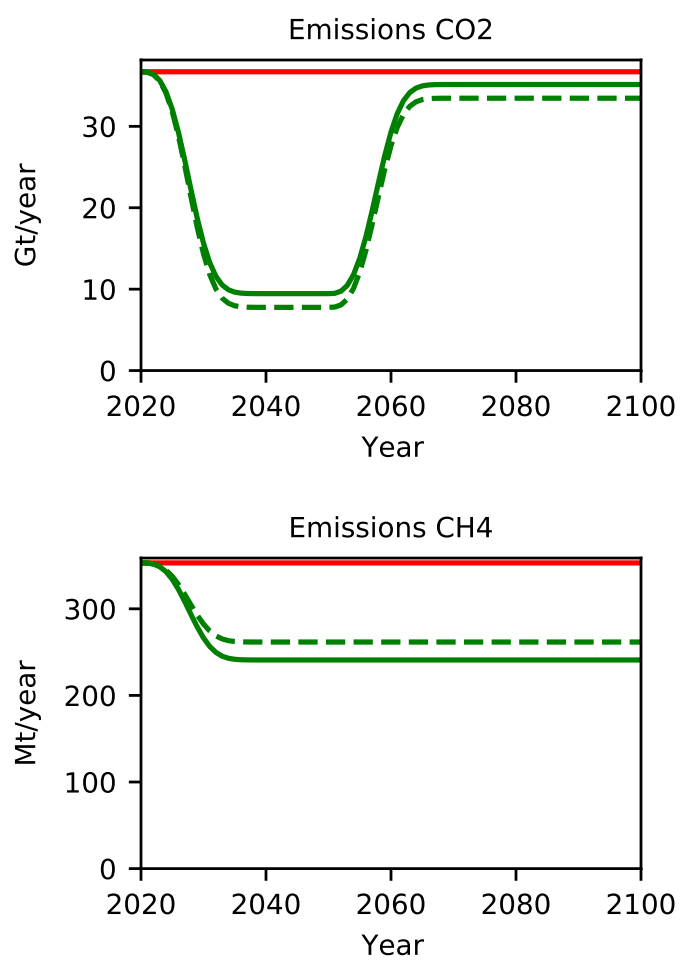

Emissions N2O

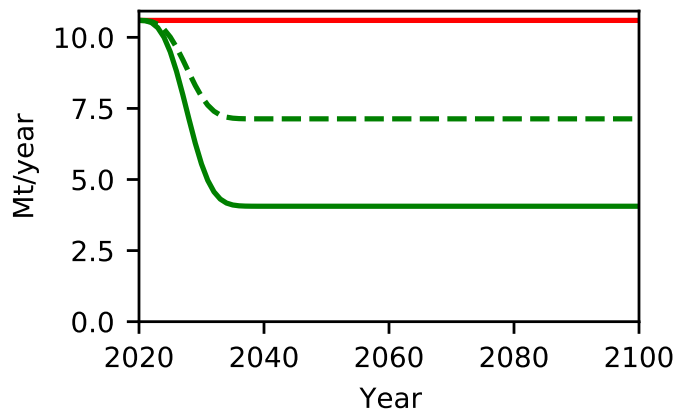

Business as Usual

- Xu et al. Animal Ag Emissions

PHASE-POD (Default)
B
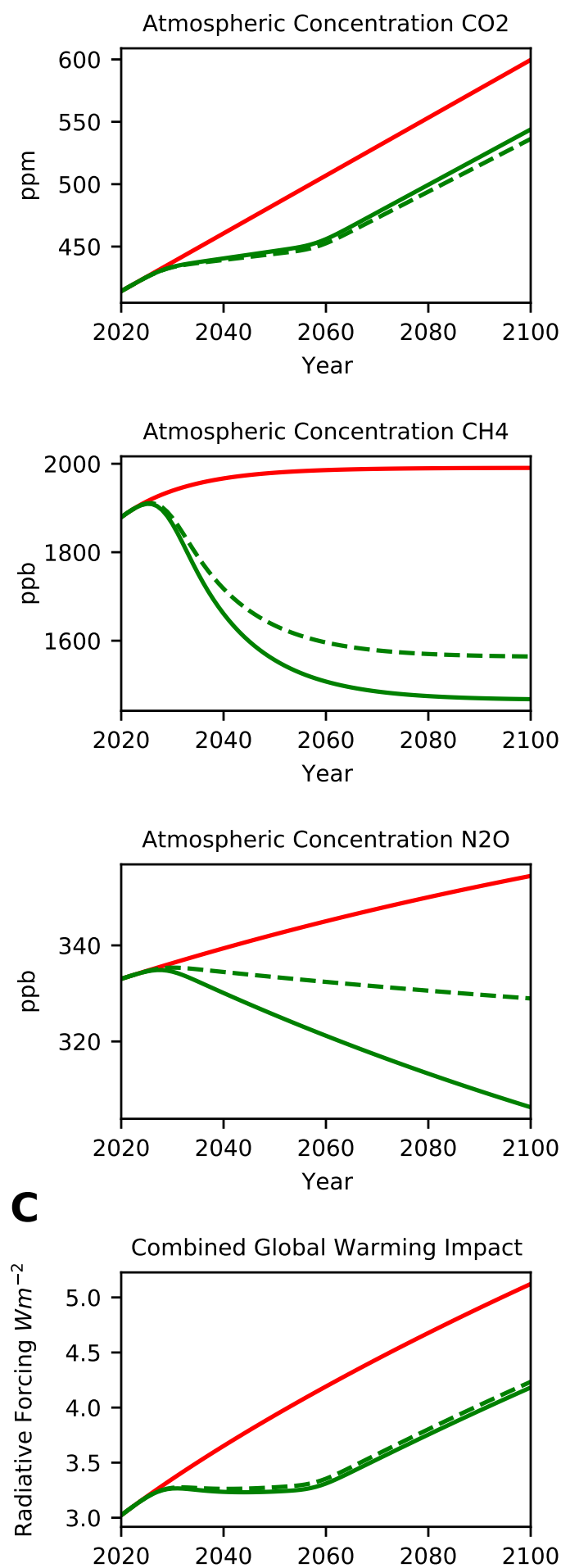

Figure 2-S11. FAO vs. Xu Emissions.

(A) Projected annual emissions of $\mathrm{CO}_{2}, \mathrm{CH}_{4}$ and $\mathrm{N}_{2} \mathrm{O}$ for each scenarios. (B) Projected atmospheric concentrations of $\mathrm{CO}_{2}, \mathrm{CH}_{4}$ and $\mathrm{N}_{2} \mathrm{O}$ under each emission scenario. (C)

Radiative Forcing (RF) inferred from atmospheric concentrations in (B) by formula of (Myhre et al., 1998; Ramaswamy et al., 2001) as modified in MAGICC6 (Meinshausen et al., 2011). Only differences between PHASE-POD default assumptions (15yr phaseout, 30yr carbon recovery, 100\% carbon recovery, BAU non-agriculture emissions, FAO crop replacement, and FAO animal ag emissions) are given. 
bioRxiv preprint doi: https://doi.org/10.1101/2021.04.15.440019; this version posted October 12, 2021. The copyright holder for this preprint (which was not certified by peer review) is the author/funder, who has granted bioRxiv a license to display the preprint in perpetuity. It is made available under aCC-BY 4.0 International license.

\section{A}
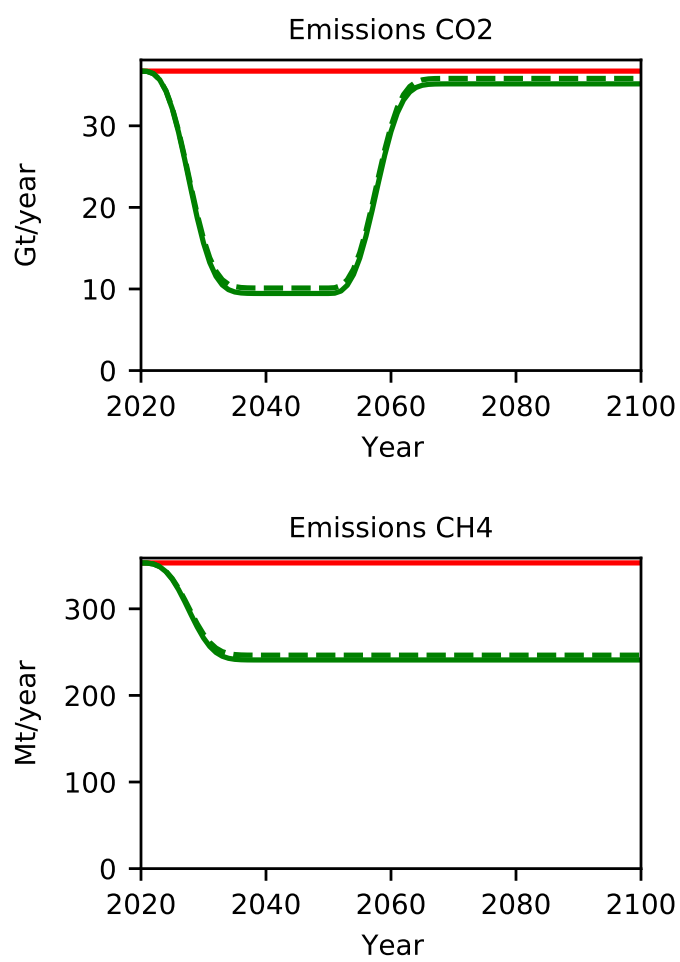

Emissions N2O

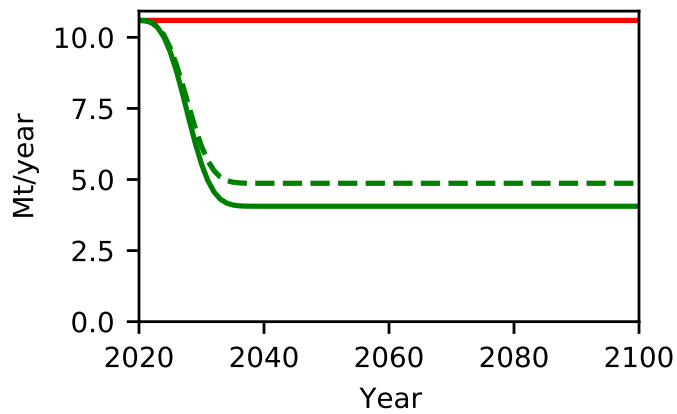

Business as Usual

- Xu et al. Replacement Diet

PHASE-POD (Default)
B
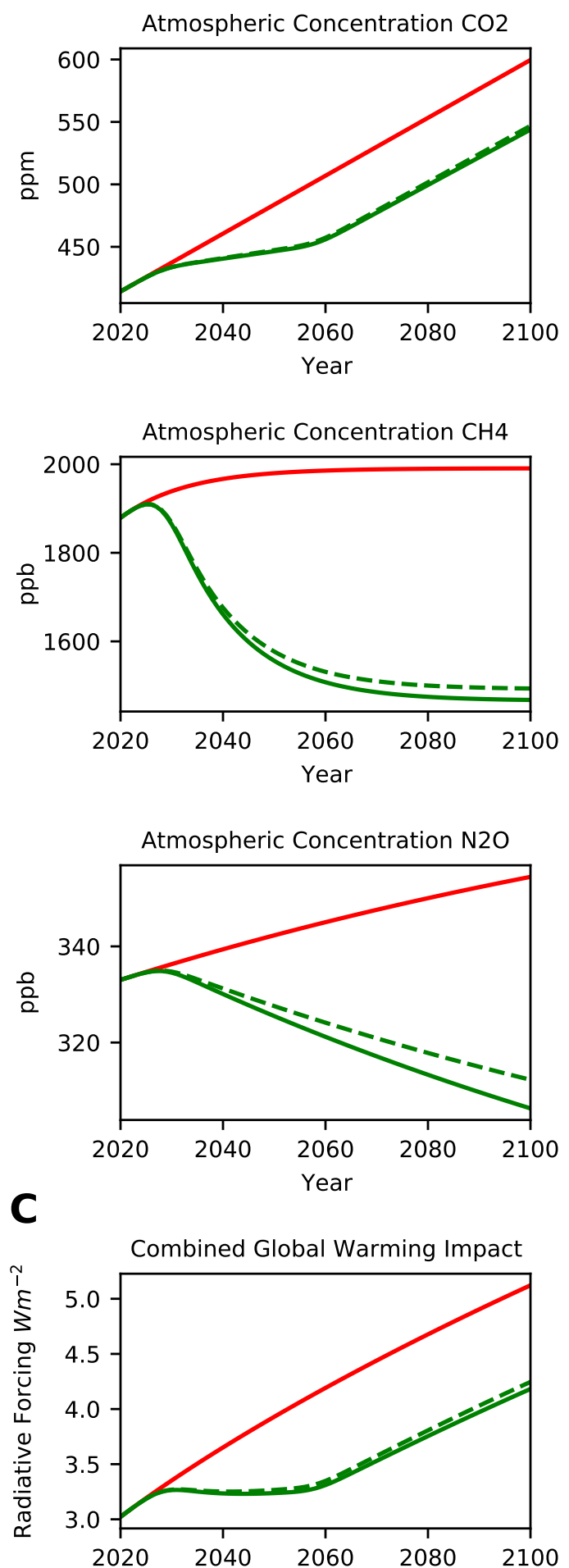

Figure 2-S12. FAO vs. Xu Replacement Diet.

(A) Projected annual emissions of $\mathrm{CO}_{2}, \mathrm{CH}_{4}$ and $\mathrm{N}_{2} \mathrm{O}$ for each scenarios. (B) Projected atmospheric concentrations of $\mathrm{CO}_{2}, \mathrm{CH}_{4}$ and $\mathrm{N}_{2} \mathrm{O}$ under each emission scenario. (C)

Radiative Forcing (RF) inferred from atmospheric concentrations in (B) by formula of (Myhre et al., 1998; Ramaswamy et al., 2001) as modified in MAGICC6 (Meinshausen et al., 2011). Only differences between PHASE-POD default assumptions (15yr phaseout, 30yr carbon recovery, 100\% carbon recovery, BAU non-agriculture emissions, FAO crop replacement, and FAO animal ag emissions) are given. 
bioRxiv preprint doi: https://doi.org/10.1101/2021.04.15.440019; this version posted October 12, 2021. The copyright holder for this preprint (which was not certified by peer review) is the author/funder, who has granted bioRxiv a license to display the preprint in perpetuity. It is made available under aCC-BY 4.0 International license.

A

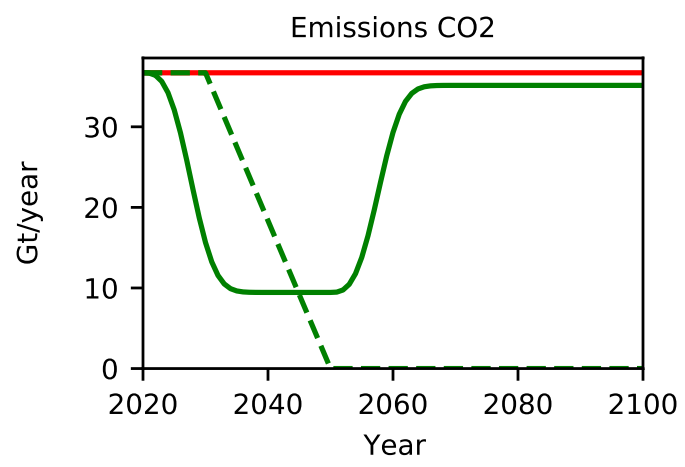

Emissions $\mathrm{CH} 4$

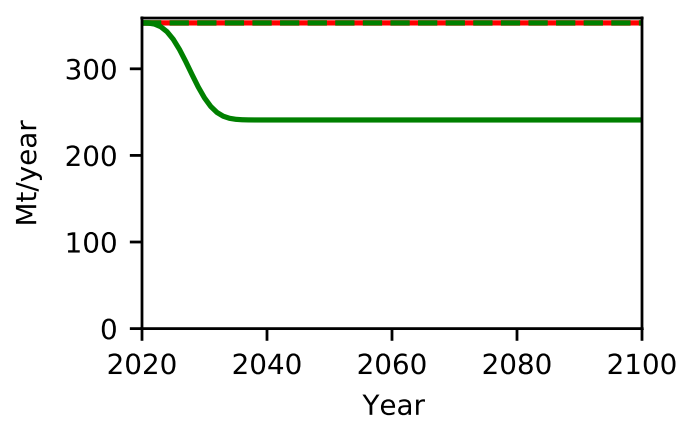

Emissions N2O

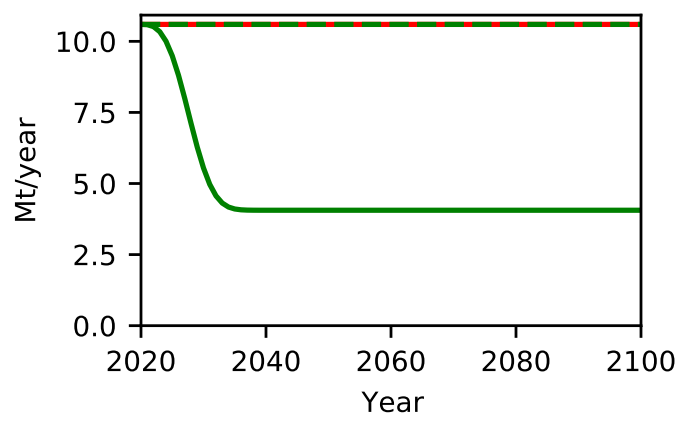

Business as Usual

- Zero Non-ag CO2 by 2050

PHASE-POD (Default)
B
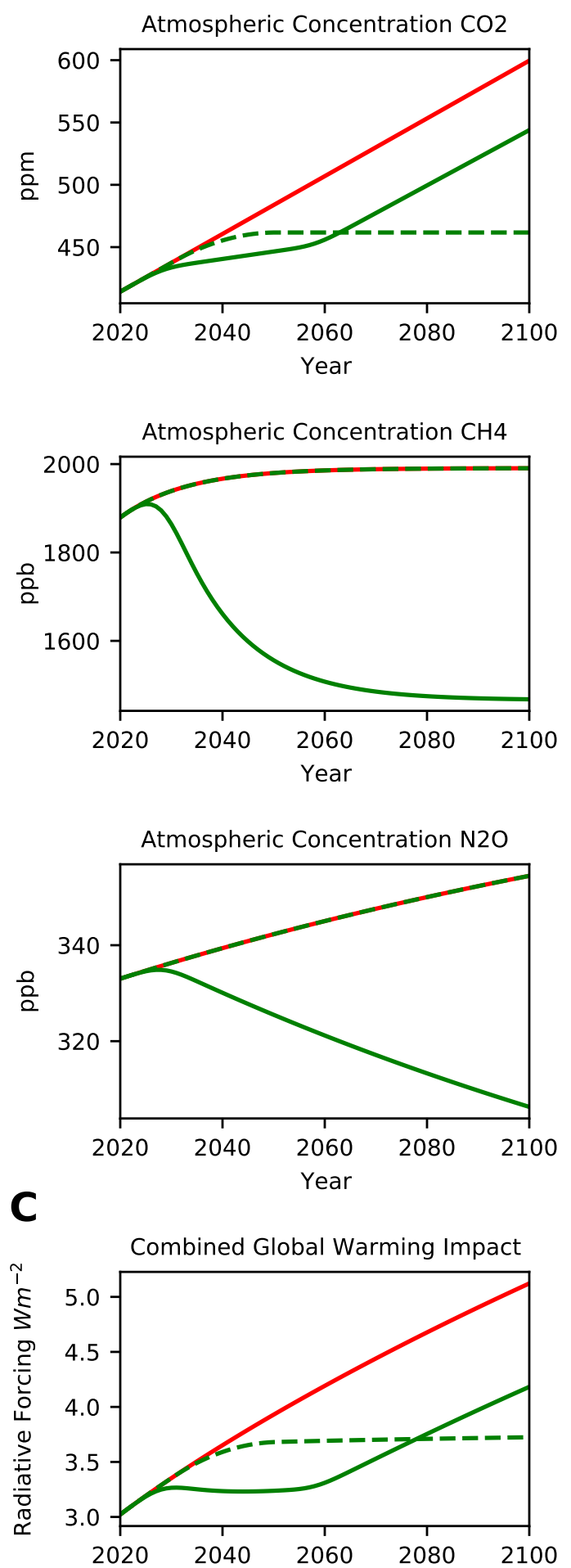

Figure 2-S13. 15yr Phaseout vs. Net Zero CO2.

(A) Projected annual emissions of $\mathrm{CO}_{2}, \mathrm{CH}_{4}$ and $\mathrm{N}_{2} \mathrm{O}$ for each scenarios. (B) Projected atmospheric concentrations of $\mathrm{CO}_{2}, \mathrm{CH}_{4}$ and $\mathrm{N}_{2} \mathrm{O}$ under each emission scenario. (C)

Radiative Forcing (RF) inferred from atmospheric concentrations in (B) by formula of (Myhre et al., 1998; Ramaswamy et al., 2001) as modified in MAGICC6 (Meinshausen et al., 2011). Only differences between PHASE-POD default assumptions (15yr phaseout, 30yr carbon recovery, 100\% carbon recovery, BAU non-agriculture emissions, FAO crop replacement, and FAO animal ag emissions) are given. 
bioRxiv preprint doi: https://doi.org/10.1101/2021.04.15.440019; this version posted October 12, 2021. The copyright holder for this preprint (which was not certified by peer review) is the author/funder, who has granted bioRxiv a license to display the preprint in perpetuity. It is made available under aCC-BY 4.0 International license.

\section{A}
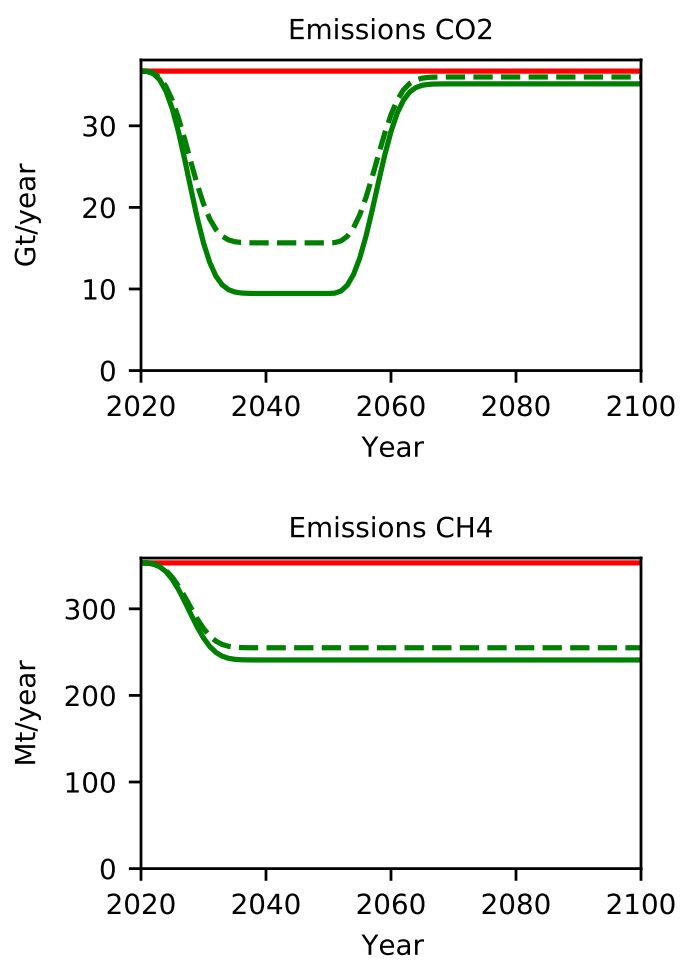

Emissions N2O

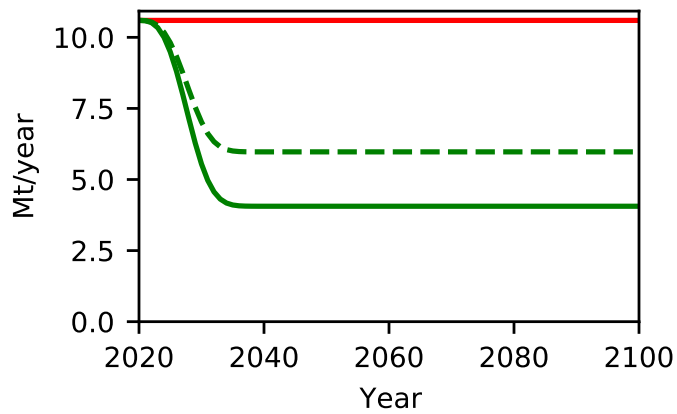

- Business as Usual
- Phaseout bovids
PHASE-POD (Default)
B
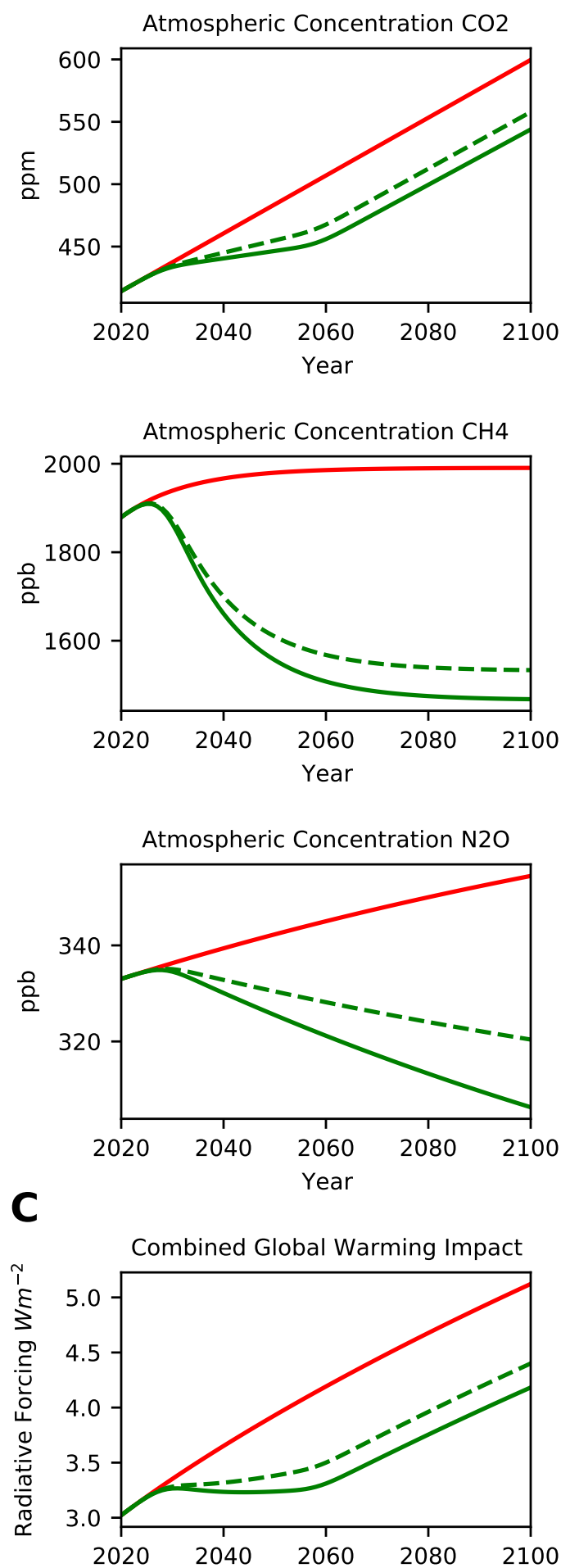

Figure 2-S14. Phaseout of Bovids.

(A) Projected annual emissions of $\mathrm{CO}_{2}, \mathrm{CH}_{4}$ and $\mathrm{N}_{2} \mathrm{O}$ for each scenarios. (B) Projected atmospheric concentrations of $\mathrm{CO}_{2}, \mathrm{CH}_{4}$ and $\mathrm{N}_{2} \mathrm{O}$ under each emission scenario. (C)

Radiative Forcing (RF) inferred from atmospheric concentrations in (B) by formula of (Myhre et al., 1998; Ramaswamy et al., 2001) as modified in MAGICC6 (Meinshausen et al., 2011). Only differences between PHASE-POD default assumptions (15yr phaseout, 30yr carbon recovery, 100\% carbon recovery, BAU non-agriculture emissions, FAO crop replacement, and FAO animal ag emissions) are given. 
bioRxiv preprint doi: https://doi.org/10.1101/2021.04.15.440019; this version posted October 12, 2021. The copyright holder for this preprint (which was not certified by peer review) is the author/funder, who has granted bioRxiv a license to display the preprint in perpetuity. It is made available under aCC-BY 4.0 International license.

\section{A}
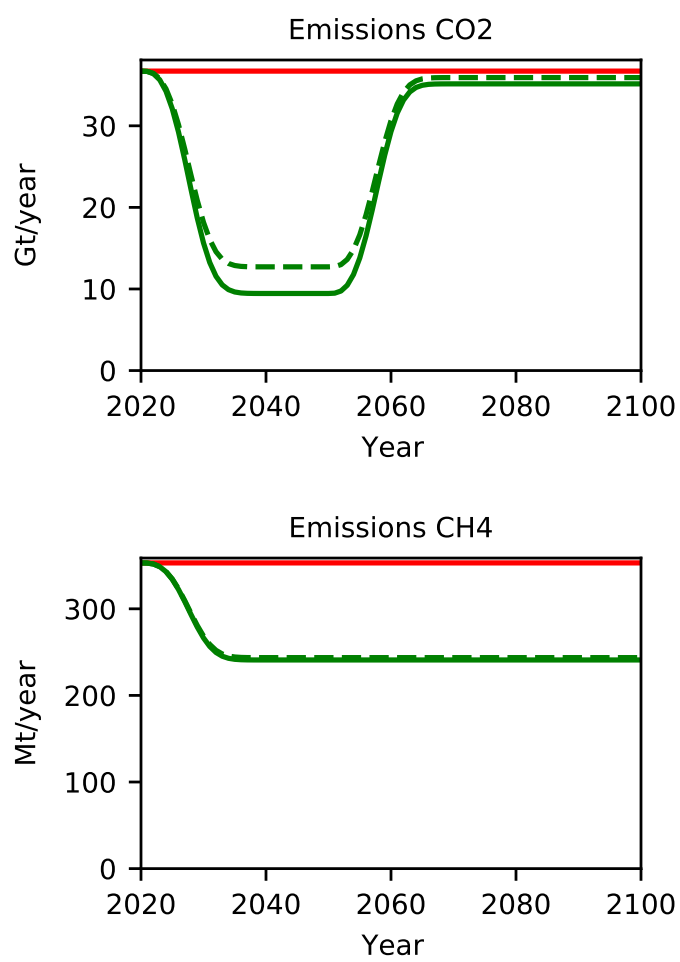

Emissions N2O

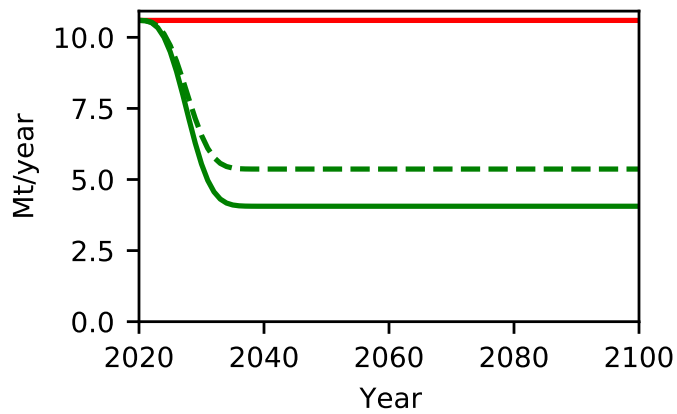

- Business as Usual
- Phaseout ruminants
PHASE-POD (Default)
B
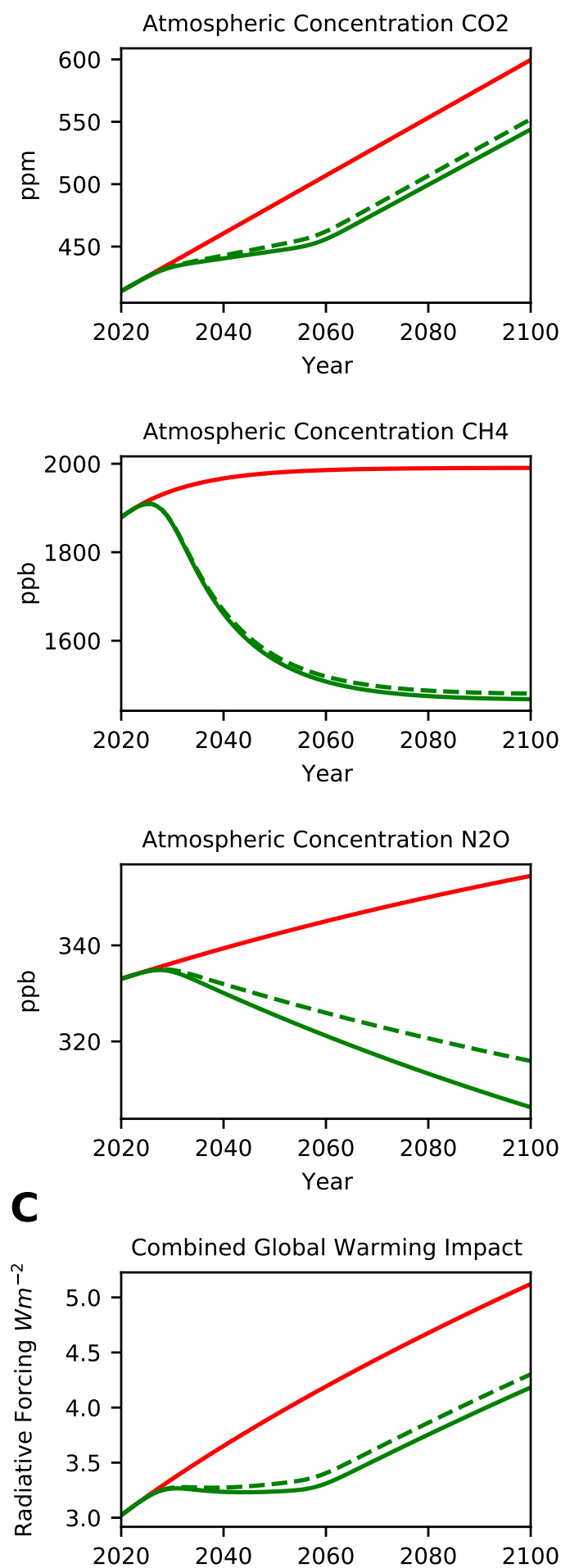

Figure 2-S15. Phaseout of Ruminants.

(A) Projected annual emissions of $\mathrm{CO}_{2}, \mathrm{CH}_{4}$ and $\mathrm{N}_{2} \mathrm{O}$ for each scenarios. (B) Projected atmospheric concentrations of $\mathrm{CO}_{2}, \mathrm{CH}_{4}$ and $\mathrm{N}_{2} \mathrm{O}$ under each emission scenario. (C)

Radiative Forcing (RF) inferred from atmospheric concentrations in (B) by formula of (Myhre et al., 1998; Ramaswamy et al., 2001) as modified in MAGICC6 (Meinshausen et al., 2011). Only differences between PHASE-POD default assumptions (15yr phaseout, 30yr carbon recovery, 100\% carbon recovery, BAU non-agriculture emissions, FAO crop replacement, and FAO animal ag emissions) are given. 
bioRxiv preprint doi: https://doi.org/10.1101/2021.04.15.440019; this version posted October 12, 2021. The copyright holder for this preprint (which was not certified by peer review) is the author/funder, who has granted bioRxiv a license to display the preprint in perpetuity. It is made available under aCC-BY 4.0 International license.

\section{A}
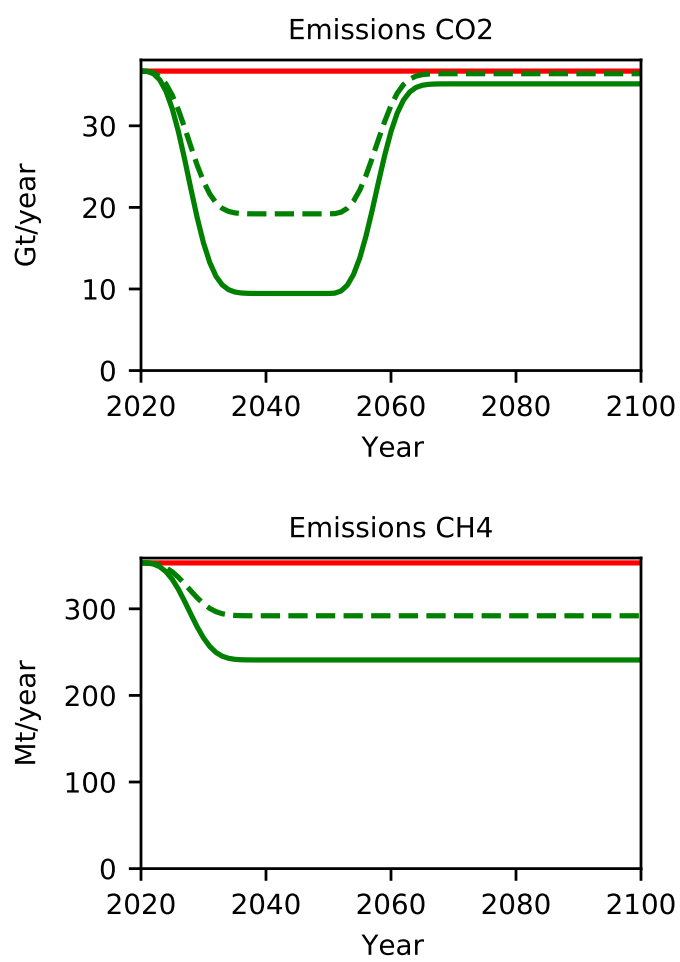

Emissions N2O

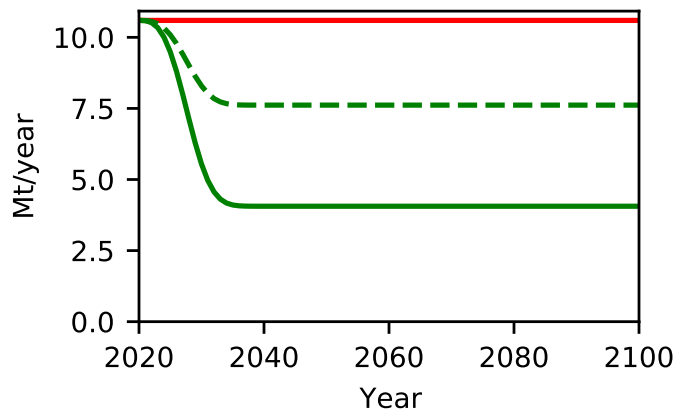

B
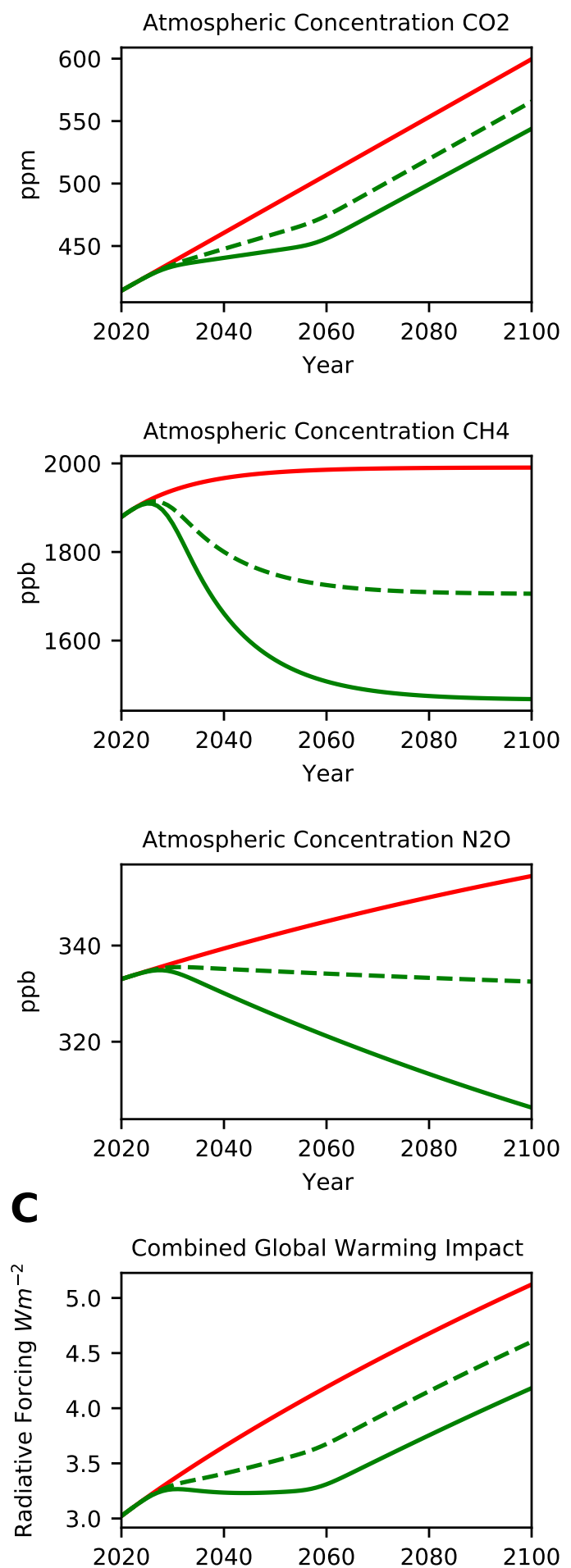

Figure 2-S16. Phaseout of Ruminant Meat.

(A) Projected annual emissions of $\mathrm{CO}_{2}, \mathrm{CH}_{4}$ and $\mathrm{N}_{2} \mathrm{O}$ for each scenarios. (B) Projected atmospheric concentrations of $\mathrm{CO}_{2}, \mathrm{CH}_{4}$ and $\mathrm{N}_{2} \mathrm{O}$ under each emission scenario. (C)

Radiative Forcing (RF) inferred from atmospheric concentrations in (B) by formula of (Myhre et al., 1998; Ramaswamy et al., 2001) as modified in MAGICC6 (Meinshausen et al., 2011). Only differences between PHASE-POD default assumptions (15yr phaseout, 30yr carbon recovery, 100\% carbon recovery, BAU non-agriculture emissions, FAO crop replacement, and FAO animal ag emissions) are given. 
bioRxiv preprint doi: https://doi.org/10.1101/2021.04.15.440019; this version posted October 12, 2021. The copyright holder for this preprint (which was not certified by peer review) is the author/funder, who has granted bioRxiv a license to display the preprint in perpetuity. It is made available under aCC-BY 4.0 International license.

\section{A}
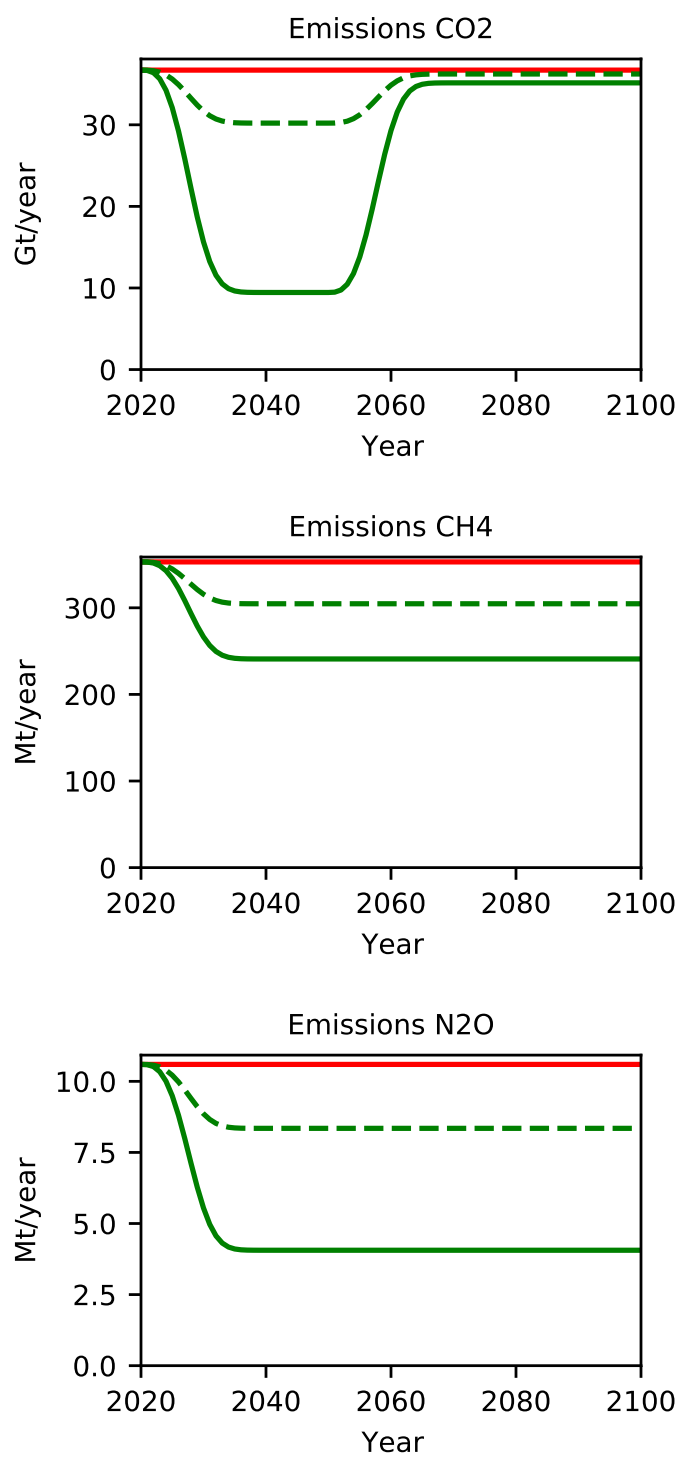

B
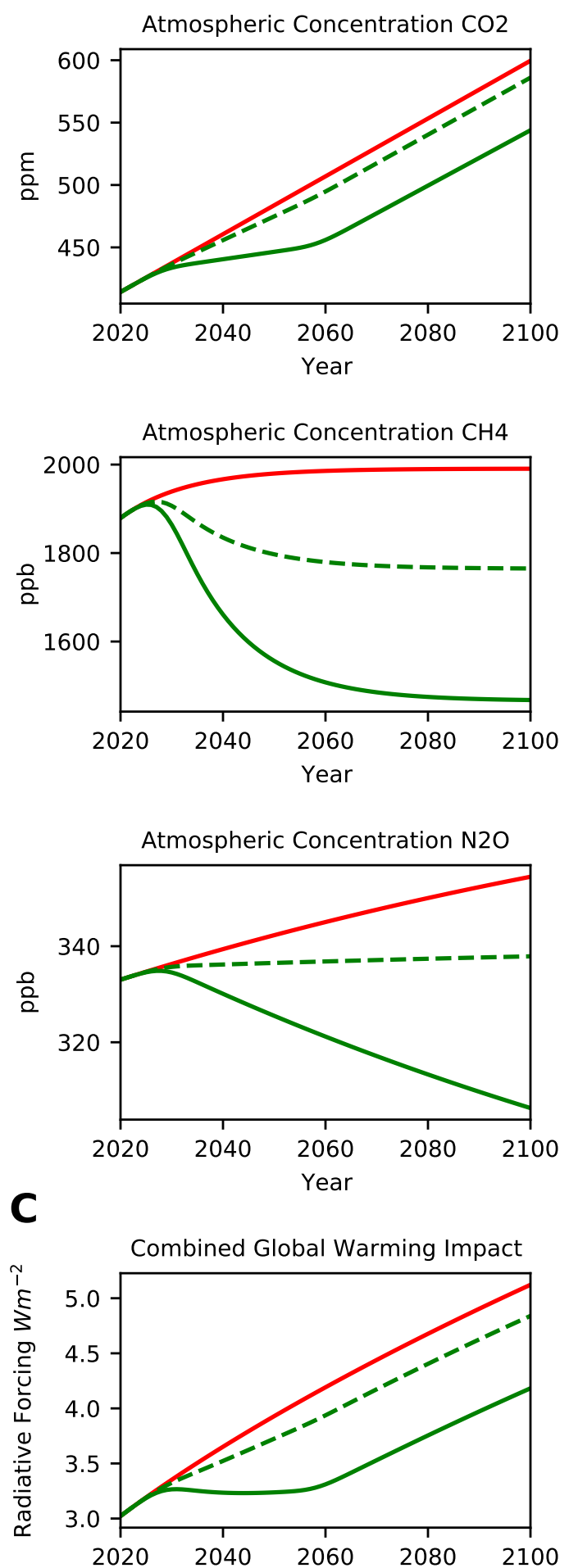

Figure 2-S17. Phaseout of Ruminant Milk.

(A) Projected annual emissions of $\mathrm{CO}_{2}, \mathrm{CH}_{4}$ and $\mathrm{N}_{2} \mathrm{O}$ for each scenarios. (B) Projected atmospheric concentrations of $\mathrm{CO}_{2}, \mathrm{CH}_{4}$ and $\mathrm{N}_{2} \mathrm{O}$ under each emission scenario. (C)

Radiative Forcing (RF) inferred from atmospheric concentrations in (B) by formula of (Myhre et al., 1998; Ramaswamy et al., 2001) as modified in MAGICC6 (Meinshausen et al., 2011). Only differences between PHASE-POD default assumptions (15yr phaseout, 30yr carbon recovery, 100\% carbon recovery, BAU non-agriculture emissions, FAO crop replacement, and FAO animal ag emissions) are given. 
bioRxiv preprint doi: https://doi.org/10.1101/2021.04.15.440019; this version posted October 12, 2021. The copyright holder for this preprint (which was not certified by peer review) is the author/funder, who has granted bioRxiv a license to display the preprint in perpetuity. It is made available under aCC-BY 4.0 International license.

\section{A}

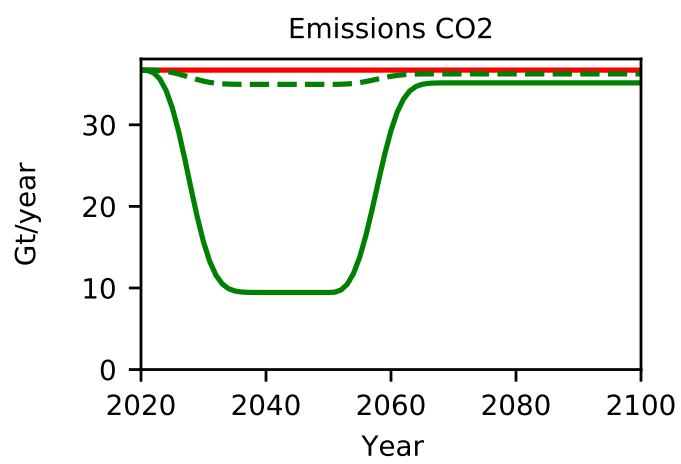

Emissions $\mathrm{CH} 4$

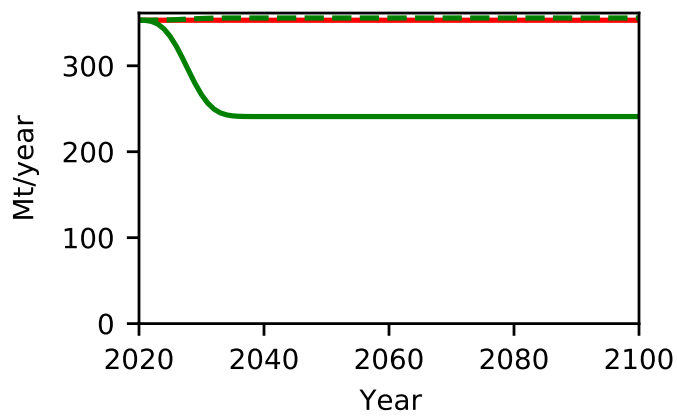

Emissions N2O

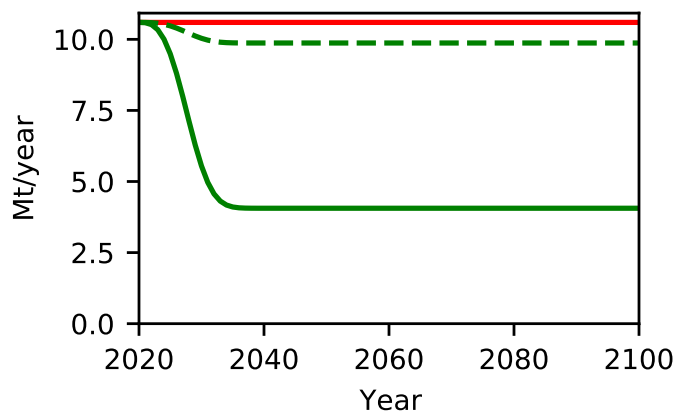

Business as Usual

- - Phaseout poultry

- PHASE-POD (Default)
B
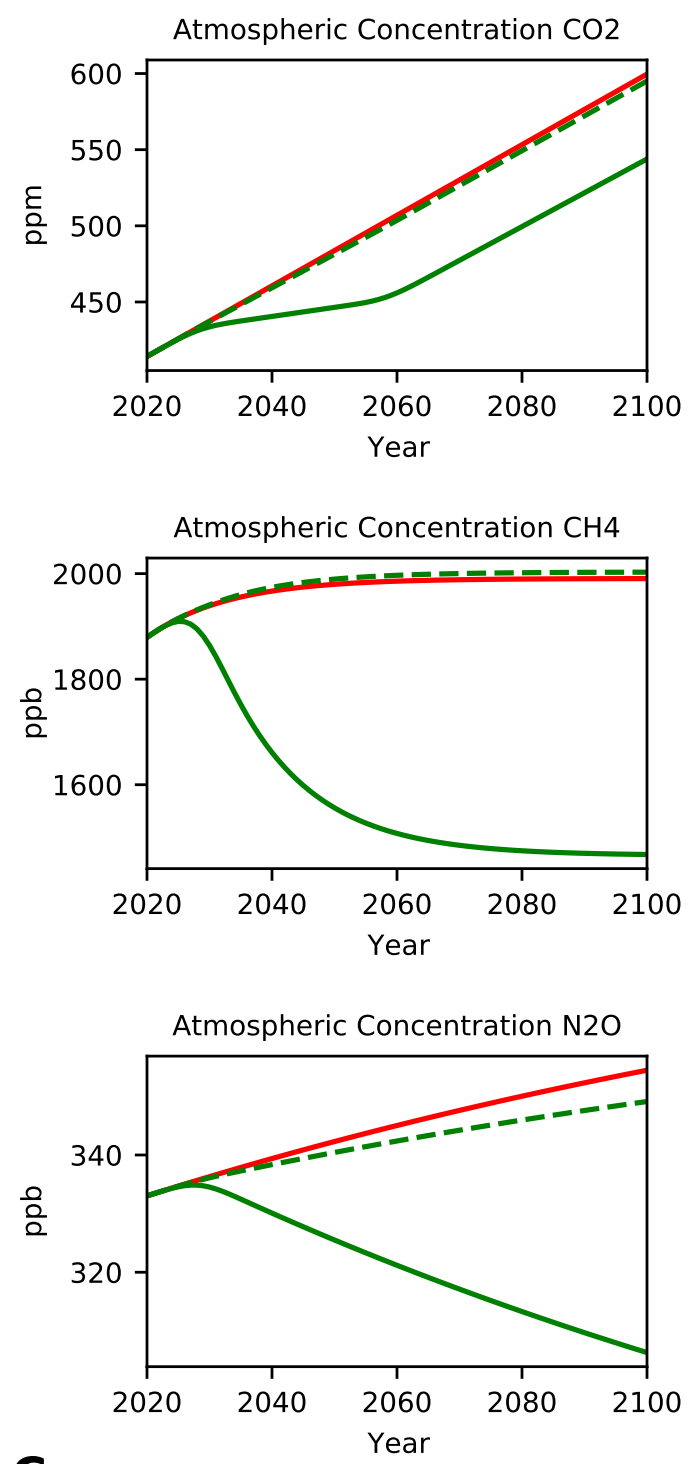

C

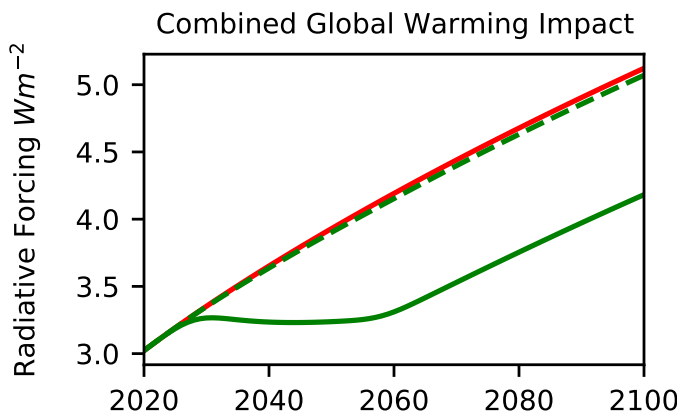

Figure 2-S18. Phaseout of Poultry.

(A) Projected annual emissions of $\mathrm{CO}_{2}, \mathrm{CH}_{4}$ and $\mathrm{N}_{2} \mathrm{O}$ for each scenarios. (B) Projected atmospheric concentrations of $\mathrm{CO}_{2}, \mathrm{CH}_{4}$ and $\mathrm{N}_{2} \mathrm{O}$ under each emission scenario. (C)

Radiative Forcing (RF) inferred from atmospheric concentrations in (B) by formula of (Myhre et al., 1998; Ramaswamy et al., 2001) as modified in MAGICC6 (Meinshausen et al., 2011). Only differences between PHASE-POD default assumptions (15yr phaseout, 30yr carbon recovery, 100\% carbon recovery, BAU non-agriculture emissions, FAO crop replacement, and FAO animal ag emissions) are given. 
bioRxiv preprint doi: https://doi.org/10.1101/2021.04.15.440019; this version posted October 12, 2021. The copyright holder for this preprint (which was not certified by peer review) is the author/funder, who has granted bioRxiv a license to display the preprint in perpetuity. It is made available under aCC-BY 4.0 International license.

\section{A}

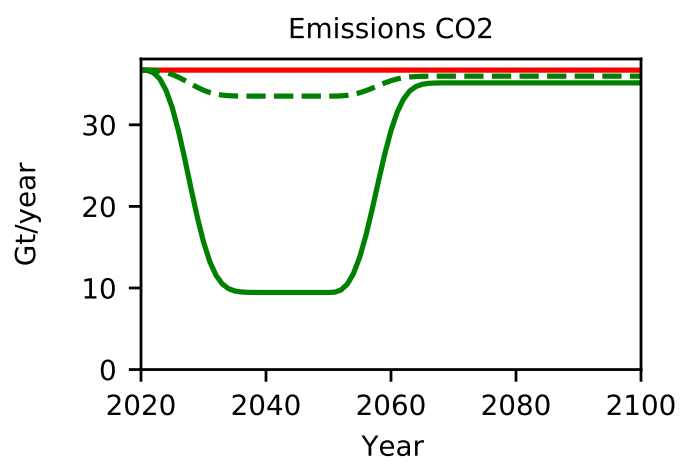

Emissions $\mathrm{CH} 4$

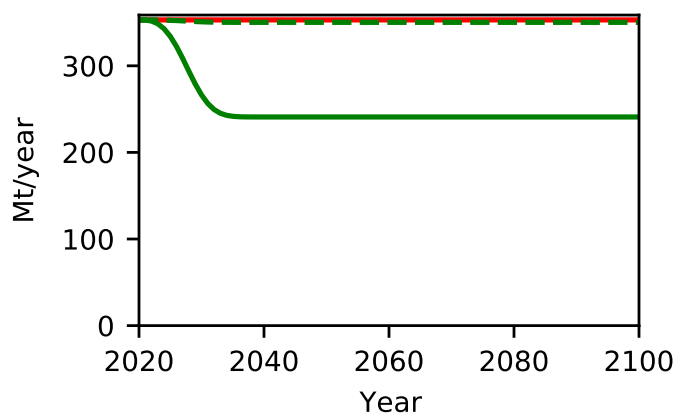

Emissions N2O

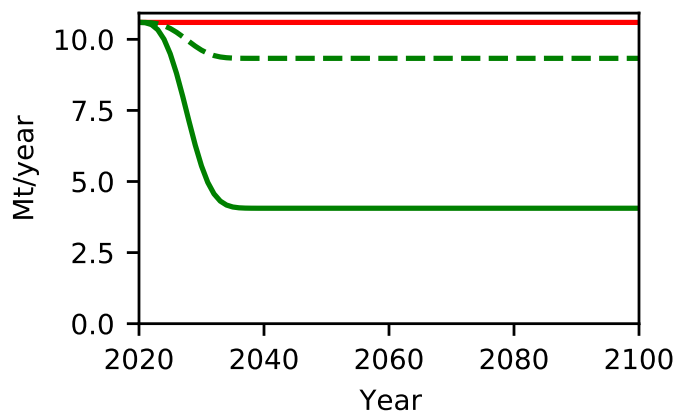

Business as Usual

- Phaseout non-ruminants

PHASE-POD (Default)
B
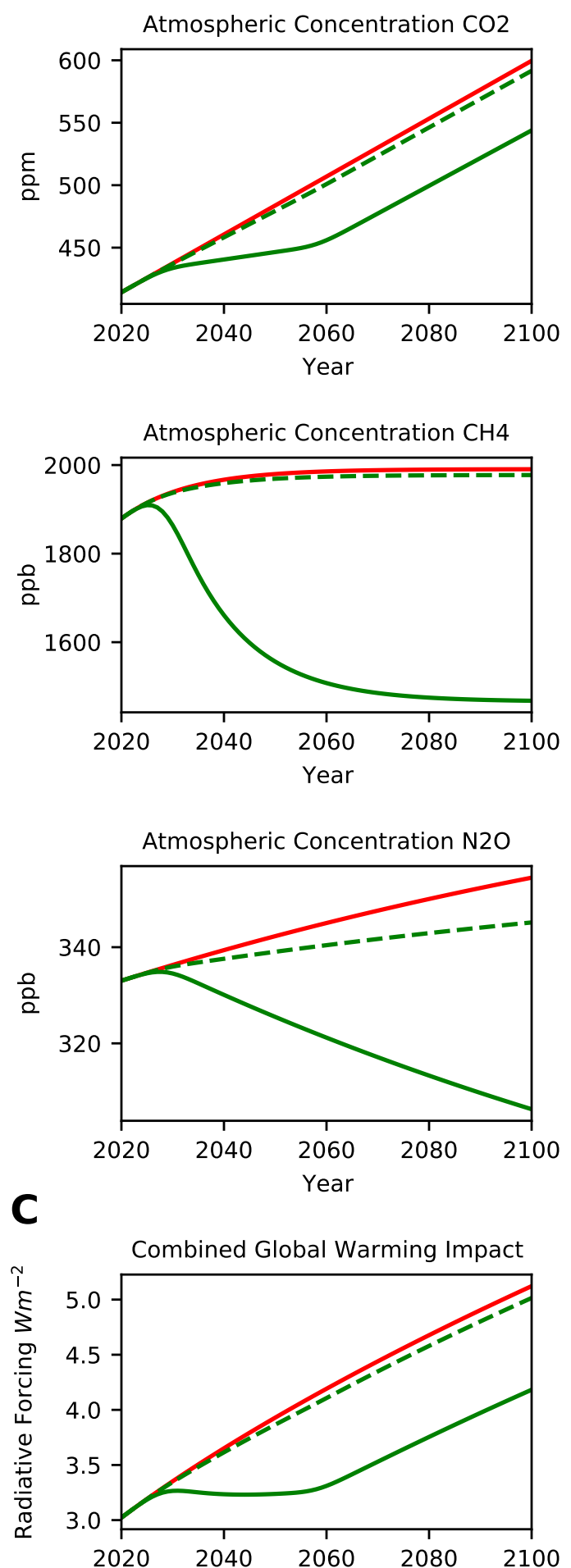

Figure 2-S19. Phaseout of Non-Ruminants.

(A) Projected annual emissions of $\mathrm{CO}_{2}, \mathrm{CH}_{4}$ and $\mathrm{N}_{2} \mathrm{O}$ for each scenarios. (B) Projected atmospheric concentrations of $\mathrm{CO}_{2}, \mathrm{CH}_{4}$ and $\mathrm{N}_{2} \mathrm{O}$ under each emission scenario. (C)

Radiative Forcing (RF) inferred from atmospheric concentrations in (B) by formula of (Myhre et al., 1998; Ramaswamy et al., 2001) as modified in MAGICC6 (Meinshausen et al., 2011). Only differences between PHASE-POD default assumptions (15yr phaseout, 30yr carbon recovery, 100\% carbon recovery, BAU non-agriculture emissions, FAO crop replacement, and FAO animal ag emissions) are given. 
bioRxiv preprint doi: https://doi.org/10.1101/2021.04.15.440019; this version posted October 12, 2021. The copyright holder for this preprint (which was not certified by peer review) is the author/funder, who has granted bioRxiv a license to display the preprint in perpetuity. It is made available under aCC-BY 4.0 International license.

\section{A}

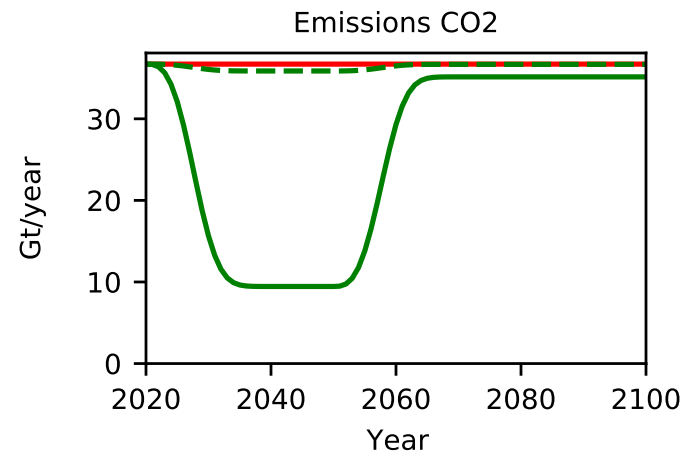

Emissions $\mathrm{CH} 4$

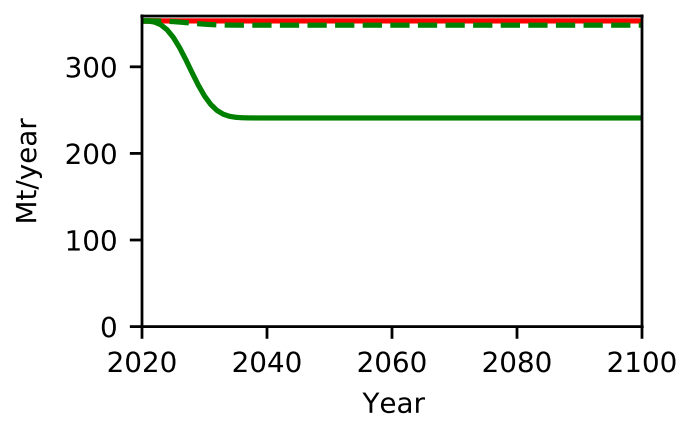

Emissions N2O

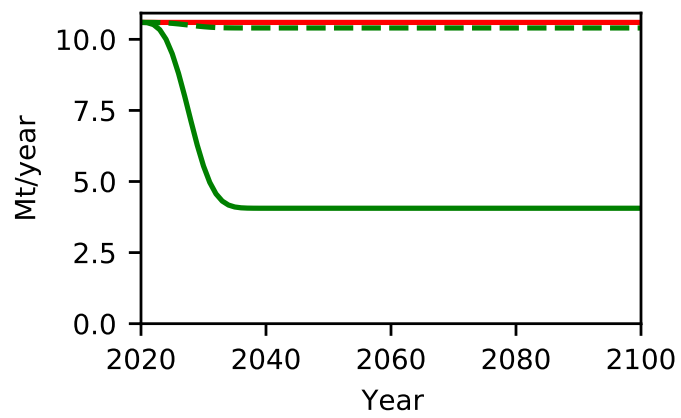

B
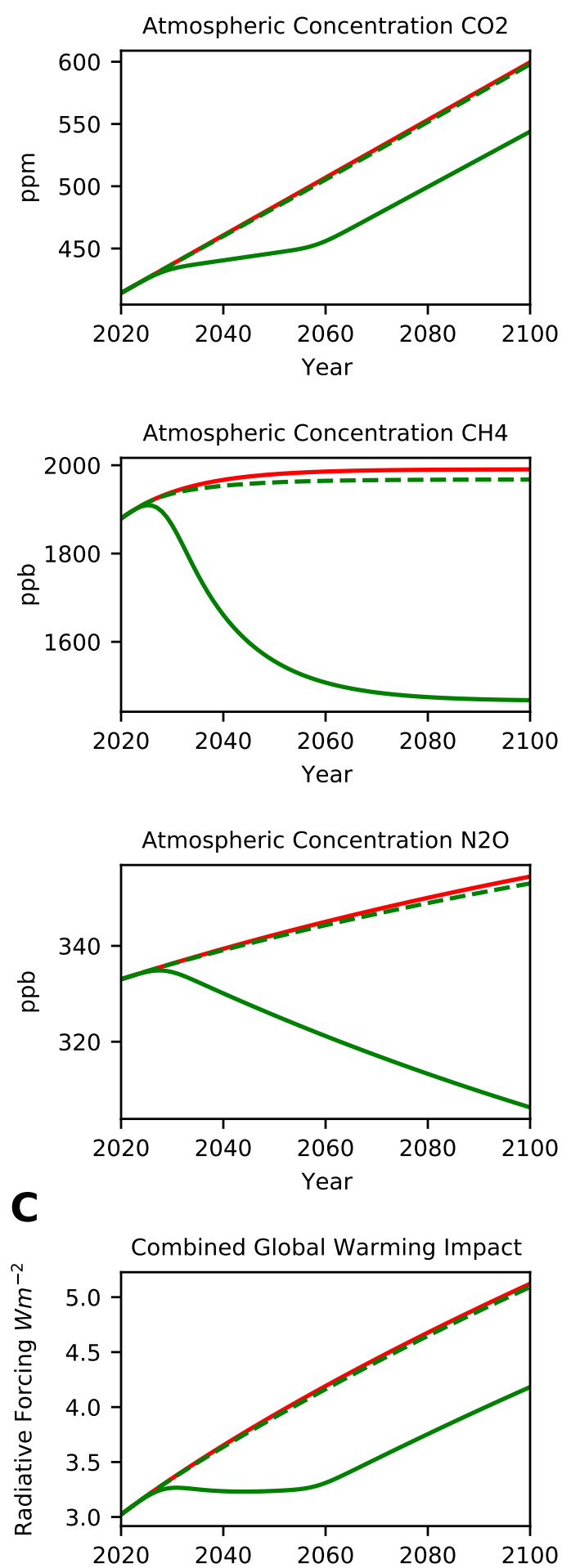

Figure 2-S20. Phaseout of Buffalo Meat.

(A) Projected annual emissions of $\mathrm{CO}_{2}, \mathrm{CH}_{4}$ and $\mathrm{N}_{2} \mathrm{O}$ for each scenarios. (B) Projected atmospheric concentrations of $\mathrm{CO}_{2}, \mathrm{CH}_{4}$ and $\mathrm{N}_{2} \mathrm{O}$ under each emission scenario. (C)

Radiative Forcing (RF) inferred from atmospheric concentrations in (B) by formula of (Myhre et al., 1998; Ramaswamy et al., 2001) as modified in MAGICC6 (Meinshausen et al., 2011). Only differences between PHASE-POD default assumptions (15yr phaseout, 30yr carbon recovery, 100\% carbon recovery, BAU non-agriculture emissions, FAO crop replacement, and FAO animal ag emissions) are given. 
bioRxiv preprint doi: https://doi.org/10.1101/2021.04.15.440019; this version posted October 12, 2021. The copyright holder for this preprint (which was not certified by peer review) is the author/funder, who has granted bioRxiv a license to display the preprint in perpetuity. It is made available under aCC-BY 4.0 International license.

\section{A}
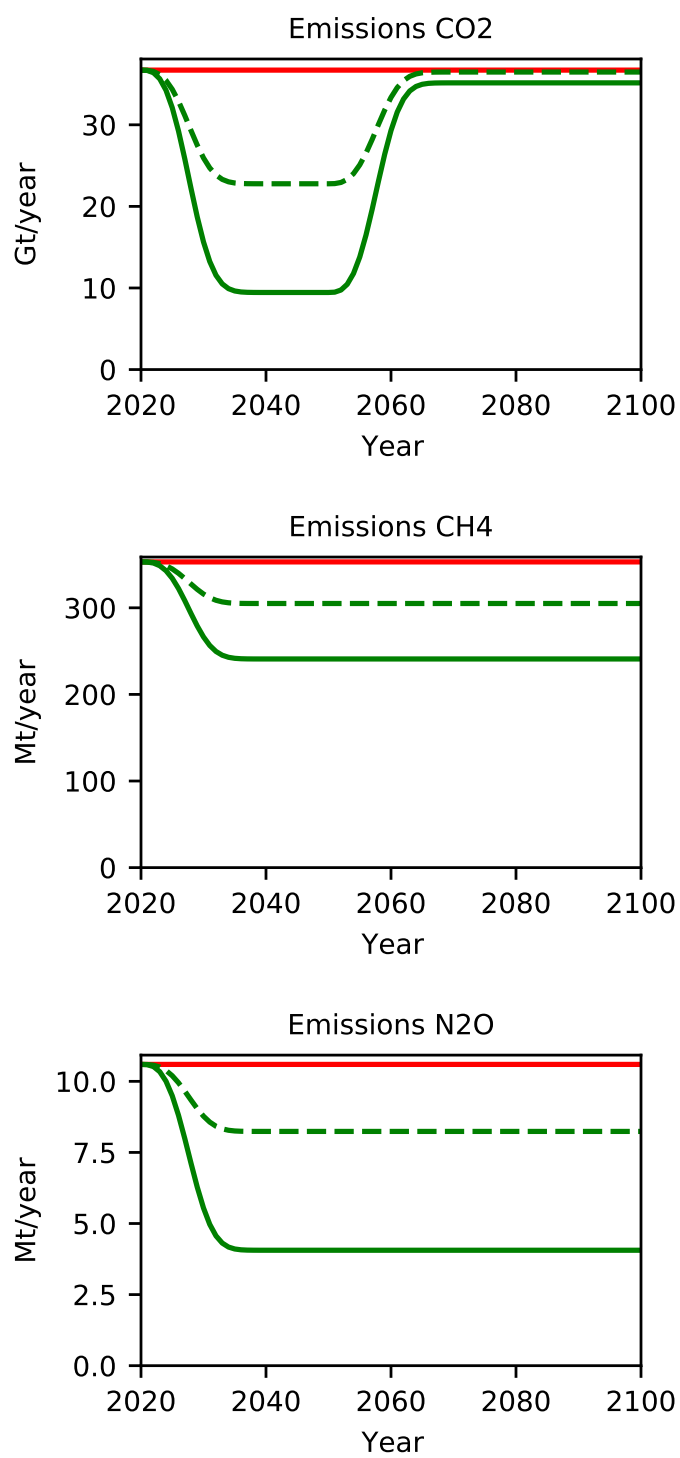

B
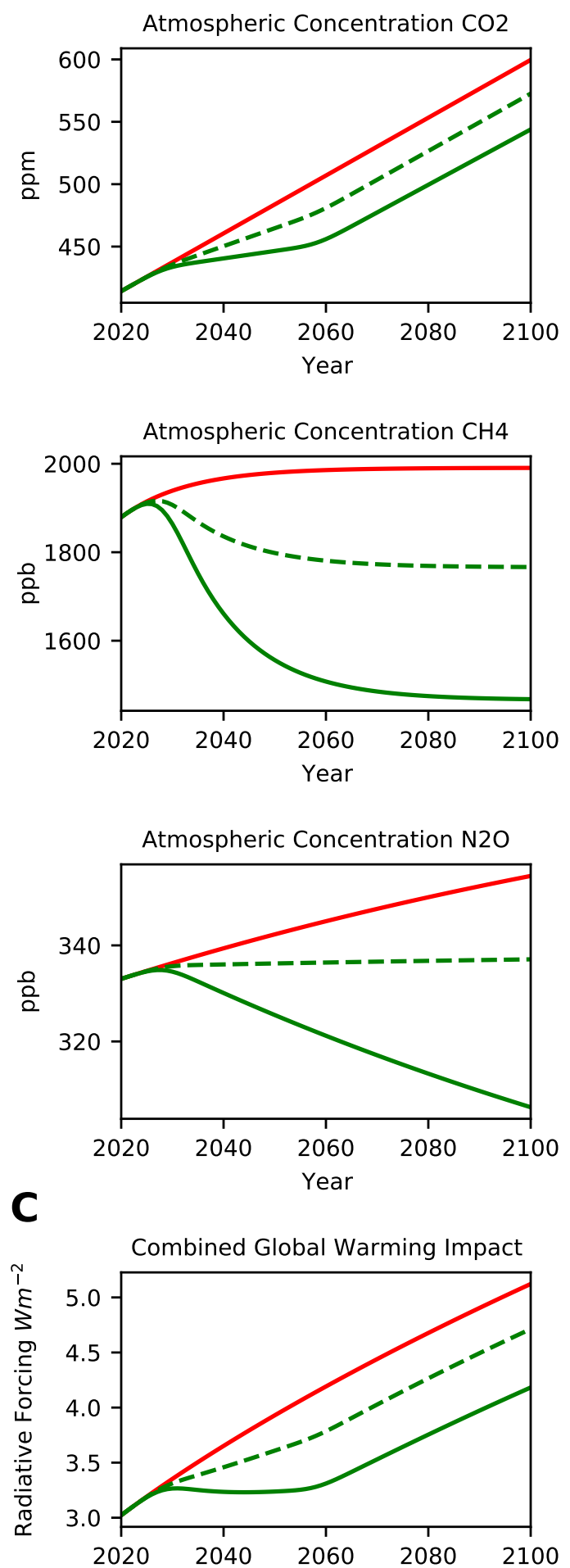

Figure 2-S21. Phaseout of Cattle Meat.

(A) Projected annual emissions of $\mathrm{CO}_{2}, \mathrm{CH}_{4}$ and $\mathrm{N}_{2} \mathrm{O}$ for each scenarios. (B) Projected atmospheric concentrations of $\mathrm{CO}_{2}, \mathrm{CH}_{4}$ and $\mathrm{N}_{2} \mathrm{O}$ under each emission scenario. (C)

Radiative Forcing (RF) inferred from atmospheric concentrations in (B) by formula of (Myhre et al., 1998; Ramaswamy et al., 2001) as modified in MAGICC6 (Meinshausen et al., 2011). Only differences between PHASE-POD default assumptions (15yr phaseout, 30yr carbon recovery, 100\% carbon recovery, BAU non-agriculture emissions, FAO crop replacement, and FAO animal ag emissions) are given. 
bioRxiv preprint doi: https://doi.org/10.1101/2021.04.15.440019; this version posted October 12, 2021. The copyright holder for this preprint (which was not certified by peer review) is the author/funder, who has granted bioRxiv a license to display the preprint in perpetuity. It is made available under aCC-BY 4.0 International license.

\section{A}

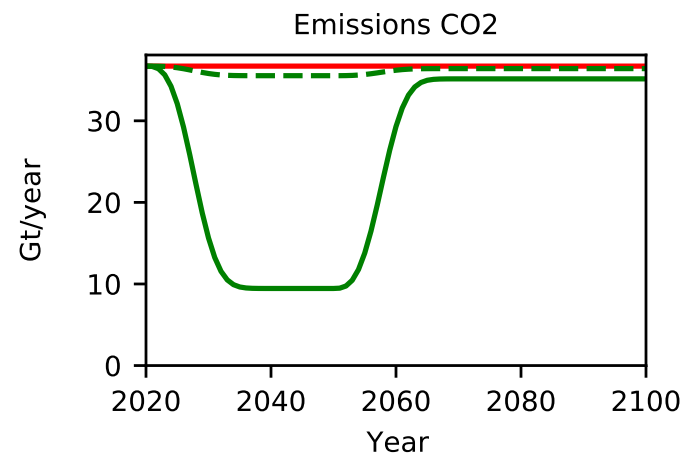

Emissions $\mathrm{CH} 4$

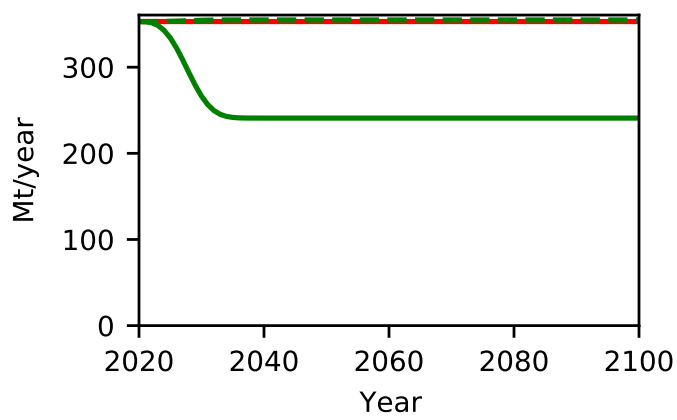

Emissions $\mathrm{N} 2 \mathrm{O}$

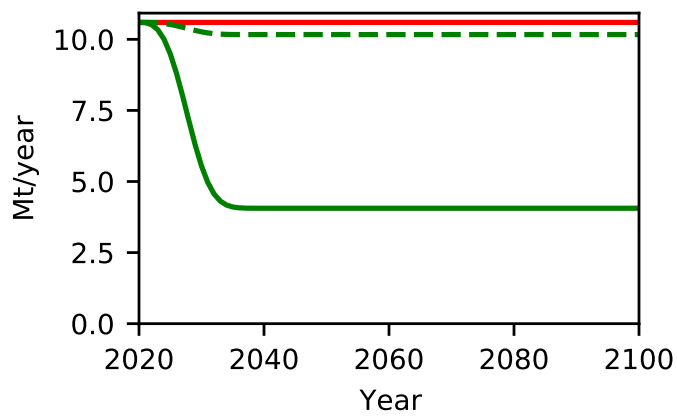

\section{B}
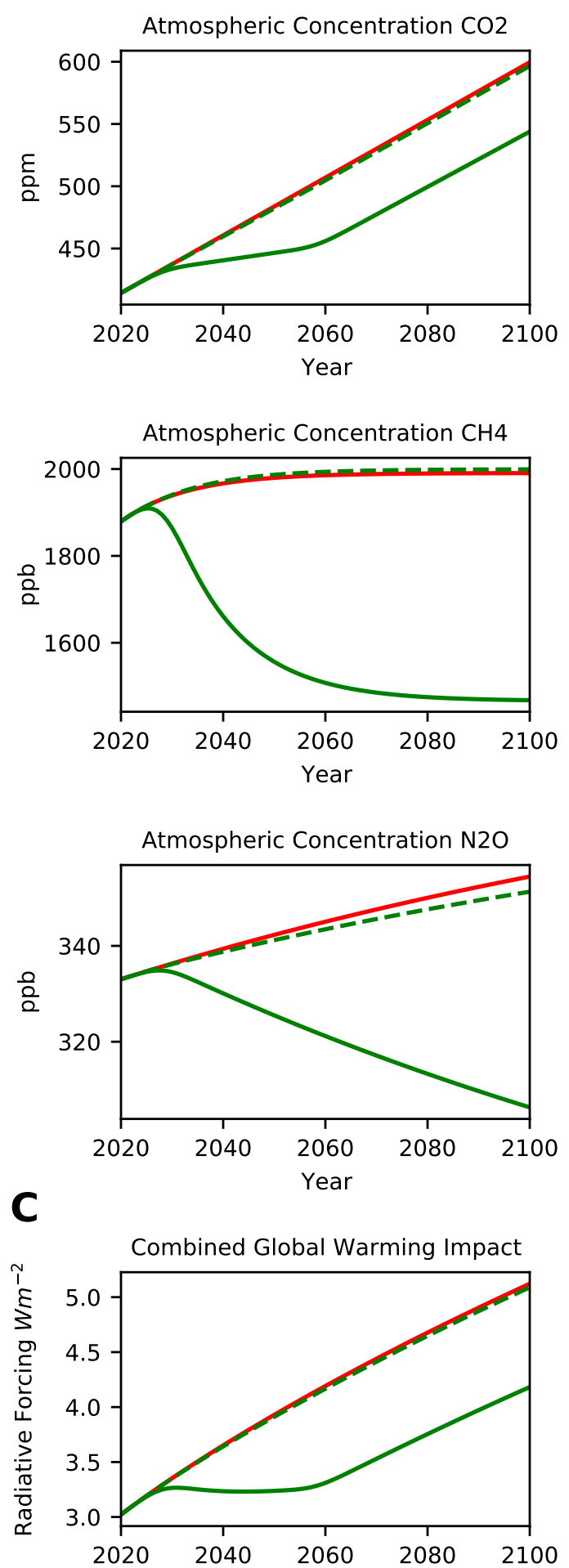

Figure 2-S22. Phaseout of Chicken Meat.

(A) Projected annual emissions of $\mathrm{CO}_{2}, \mathrm{CH}_{4}$ and $\mathrm{N}_{2} \mathrm{O}$ for each scenarios. (B) Projected atmospheric concentrations of $\mathrm{CO}_{2}, \mathrm{CH}_{4}$ and $\mathrm{N}_{2} \mathrm{O}$ under each emission scenario. (C)

Radiative Forcing (RF) inferred from atmospheric concentrations in (B) by formula of (Myhre et al., 1998; Ramaswamy et al., 2001) as modified in MAGICC6 (Meinshausen et al., 2011). Only differences between PHASE-POD default assumptions (15yr phaseout, 30yr carbon recovery, 100\% carbon recovery, BAU non-agriculture emissions, FAO crop replacement, and FAO animal ag emissions) are given. 
bioRxiv preprint doi: https://doi.org/10.1101/2021.04.15.440019; this version posted October 12, 2021. The copyright holder for this preprint (which was not certified by peer review) is the author/funder, who has granted bioRxiv a license to display the preprint in perpetuity. It is made available under aCC-BY 4.0 International license.

\section{A}
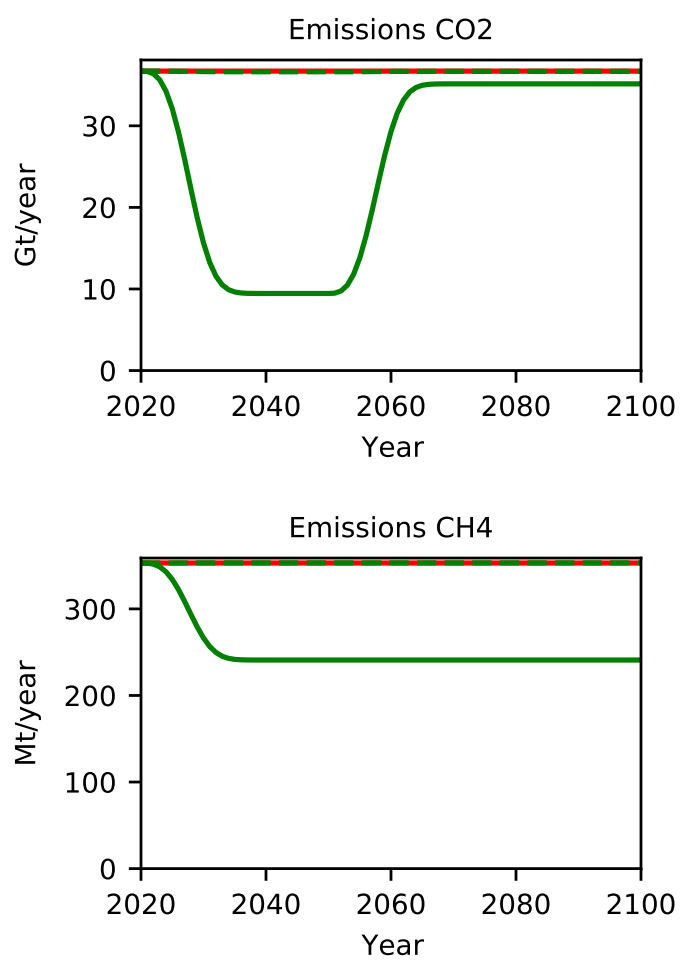

Emissions N2O

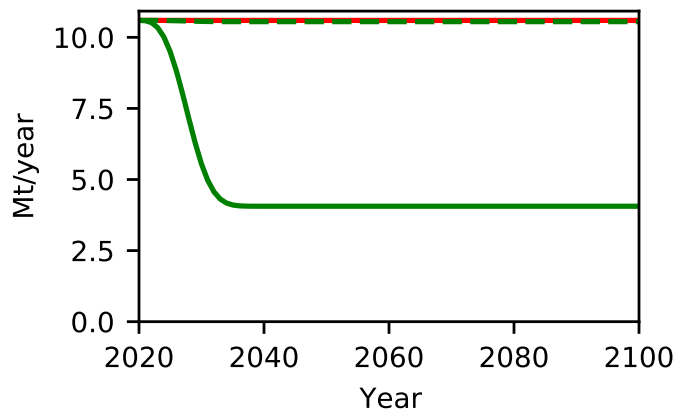

Business as Usual

- Phaseout duck meat

PHASE-POD (Default)
B
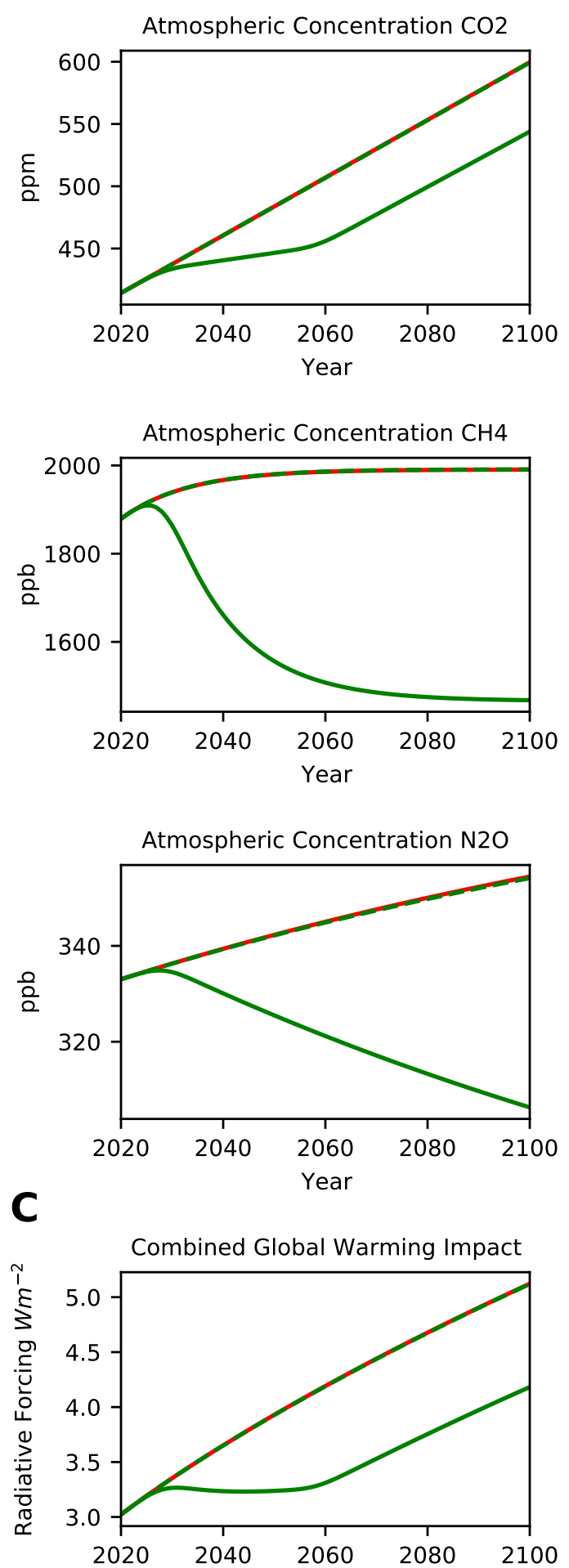

Figure 2-S23. Phaseout of Duck Meat.

(A) Projected annual emissions of $\mathrm{CO}_{2}, \mathrm{CH}_{4}$ and $\mathrm{N}_{2} \mathrm{O}$ for each scenarios. (B) Projected atmospheric concentrations of $\mathrm{CO}_{2}, \mathrm{CH}_{4}$ and $\mathrm{N}_{2} \mathrm{O}$ under each emission scenario. (C)

Radiative Forcing (RF) inferred from atmospheric concentrations in (B) by formula of (Myhre et al., 1998; Ramaswamy et al., 2001) as modified in MAGICC6 (Meinshausen et al., 2011). Only differences between PHASE-POD default assumptions (15yr phaseout, 30yr carbon recovery, 100\% carbon recovery, BAU non-agriculture emissions, FAO crop replacement, and FAO animal ag emissions) are given. 
bioRxiv preprint doi: https://doi.org/10.1101/2021.04.15.440019; this version posted October 12, 2021. The copyright holder for this preprint (which was not certified by peer review) is the author/funder, who has granted bioRxiv a license to display the preprint in perpetuity. It is made available under aCC-BY 4.0 International license.

\section{A}

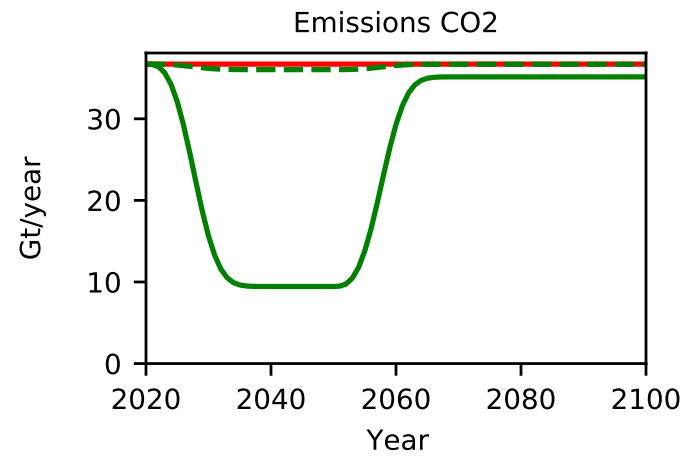

Emissions $\mathrm{CH} 4$

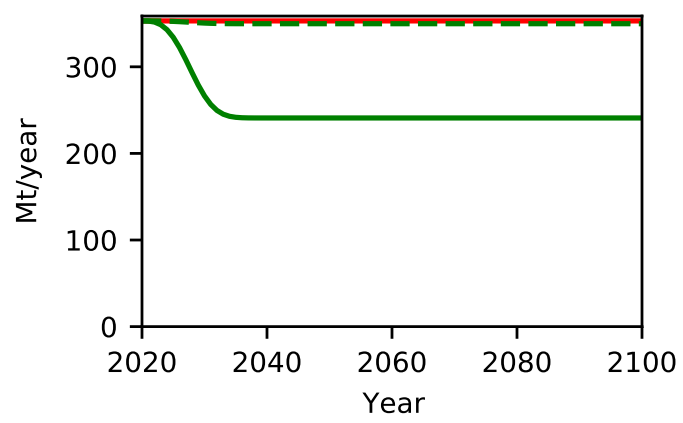

Emissions N2O

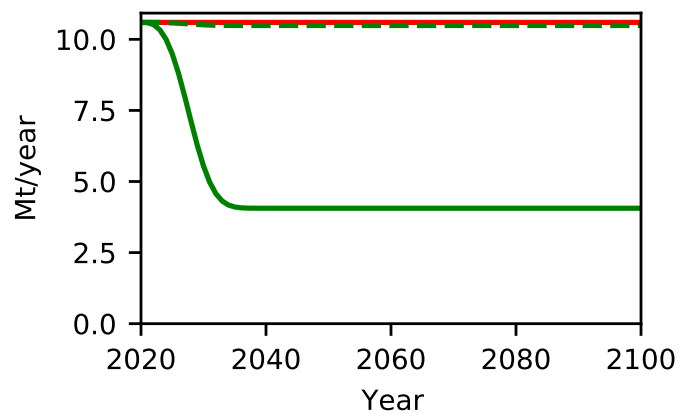

Business as Usual

- - Phaseout goat meat

PHASE-POD (Default)

\section{B}
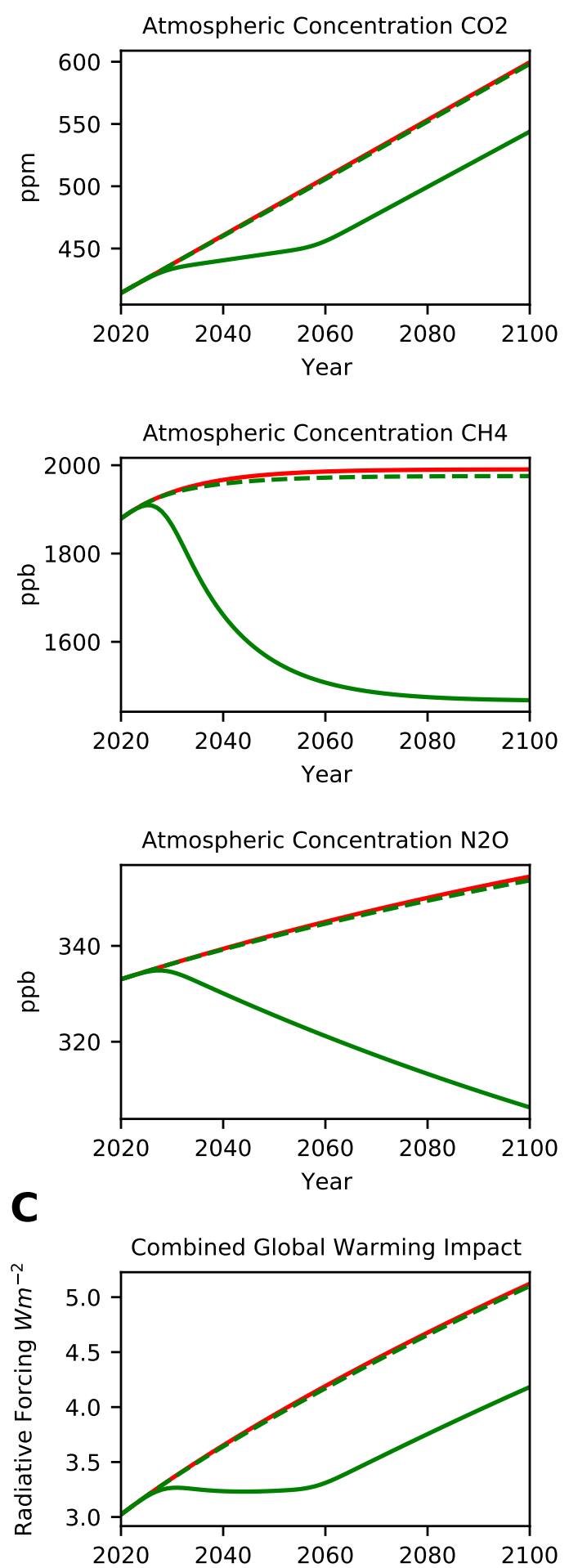

Figure 2-S24. Phaseout of Goat Meat.

(A) Projected annual emissions of $\mathrm{CO}_{2}, \mathrm{CH}_{4}$ and $\mathrm{N}_{2} \mathrm{O}$ for each scenarios. (B) Projected atmospheric concentrations of $\mathrm{CO}_{2}, \mathrm{CH}_{4}$ and $\mathrm{N}_{2} \mathrm{O}$ under each emission scenario. (C)

Radiative Forcing (RF) inferred from atmospheric concentrations in (B) by formula of (Myhre et al., 1998; Ramaswamy et al., 2001) as modified in MAGICC6 (Meinshausen et al., 2011). Only differences between PHASE-POD default assumptions (15yr phaseout, 30yr carbon recovery, 100\% carbon recovery, BAU non-agriculture emissions, FAO crop replacement, and FAO animal ag emissions) are given. 
bioRxiv preprint doi: https://doi.org/10.1101/2021.04.15.440019; this version posted October 12, 2021. The copyright holder for this preprint (which was not certified by peer review) is the author/funder, who has granted bioRxiv a license to display the preprint in perpetuity. It is made available under aCC-BY 4.0 International license.

\section{A}

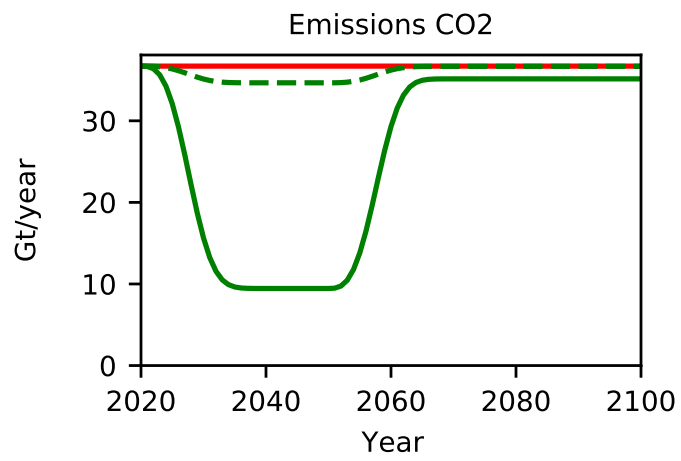

Emissions $\mathrm{CH} 4$

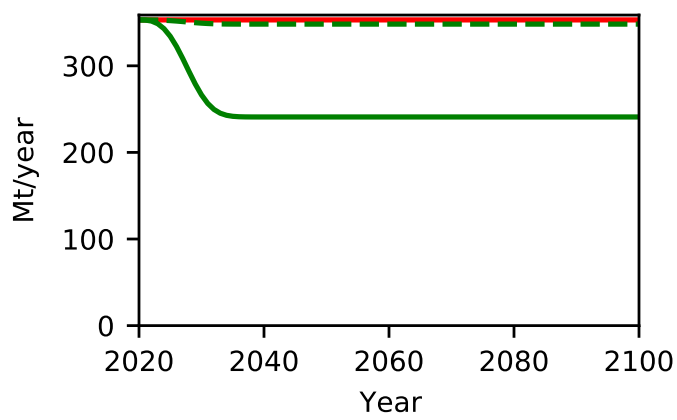

Emissions N2O

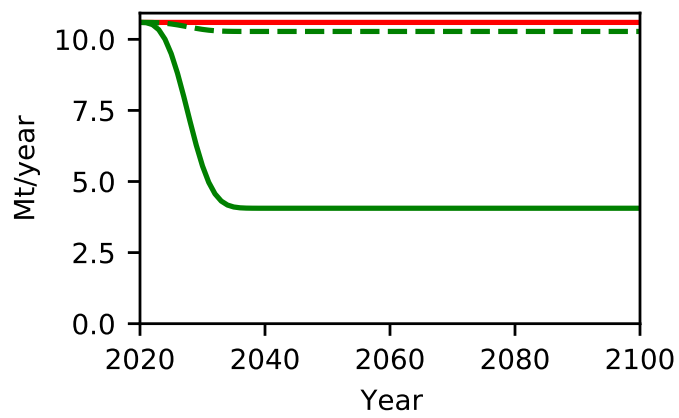

B
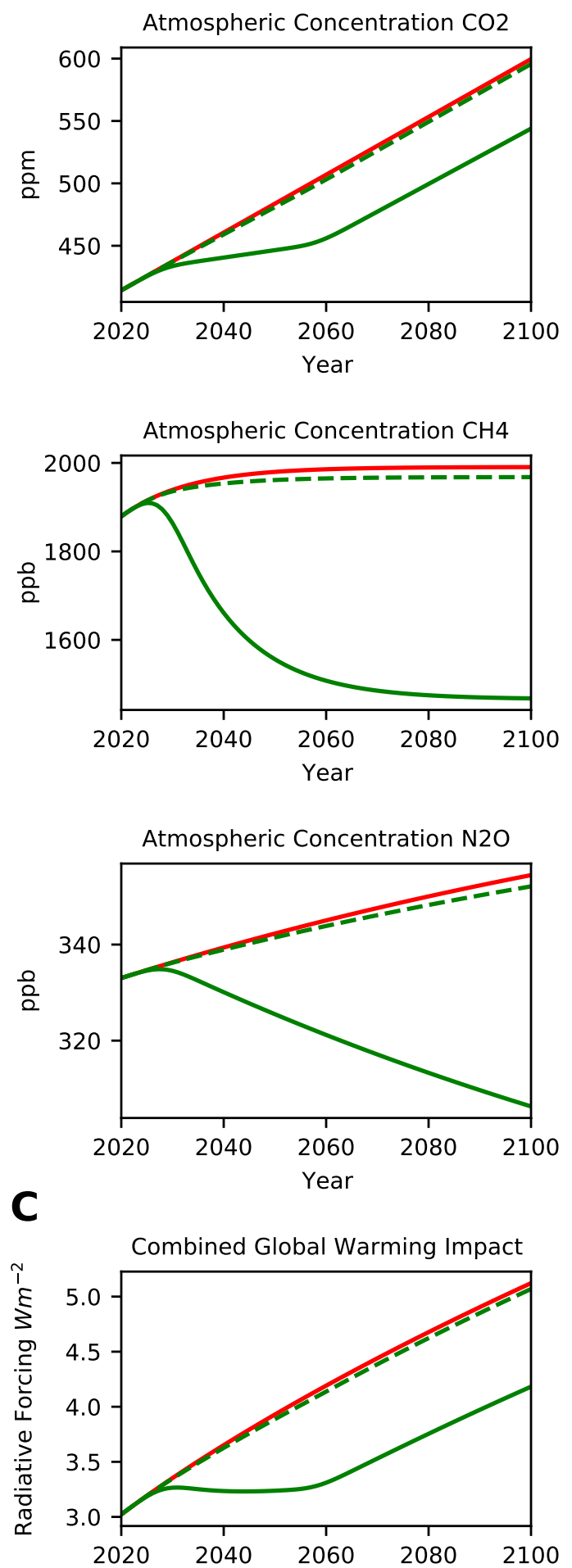

Figure 2-S25. Phaseout of Sheep Meat.

(A) Projected annual emissions of $\mathrm{CO}_{2}, \mathrm{CH}_{4}$ and $\mathrm{N}_{2} \mathrm{O}$ for each scenarios. (B) Projected atmospheric concentrations of $\mathrm{CO}_{2}, \mathrm{CH}_{4}$ and $\mathrm{N}_{2} \mathrm{O}$ under each emission scenario. (C)

Radiative Forcing (RF) inferred from atmospheric concentrations in (B) by formula of (Myhre et al., 1998; Ramaswamy et al., 2001) as modified in MAGICC6 (Meinshausen et al., 2011). Only differences between PHASE-POD default assumptions (15yr phaseout, 30yr carbon recovery, 100\% carbon recovery, BAU non-agriculture emissions, FAO crop replacement, and FAO animal ag emissions) are given. 
bioRxiv preprint doi: https://doi.org/10.1101/2021.04.15.440019; this version posted October 12, 2021. The copyright holder for this preprint (which was not certified by peer review) is the author/funder, who has granted bioRxiv a license to display the preprint in perpetuity. It is made available under aCC-BY 4.0 International license.

\section{A}

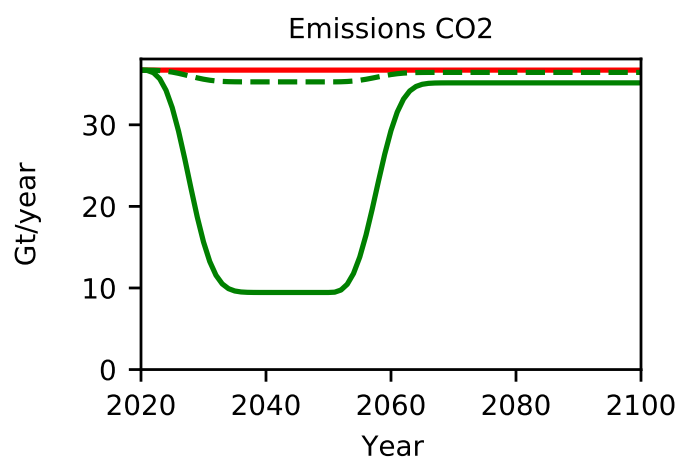

Emissions $\mathrm{CH} 4$

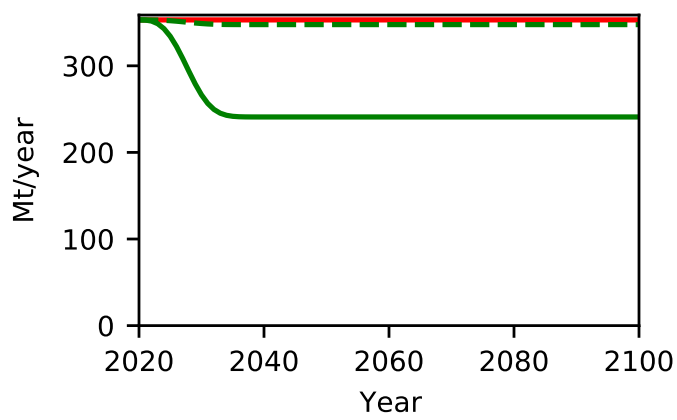

Emissions N2O

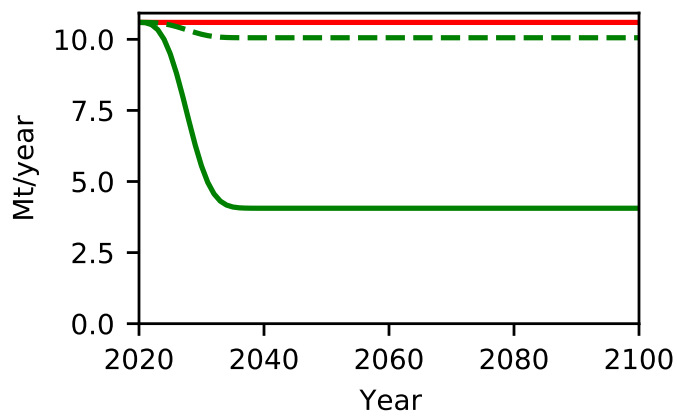

Business as Usual
- Phaseout pig meat
PHASE-POD (Default)
B
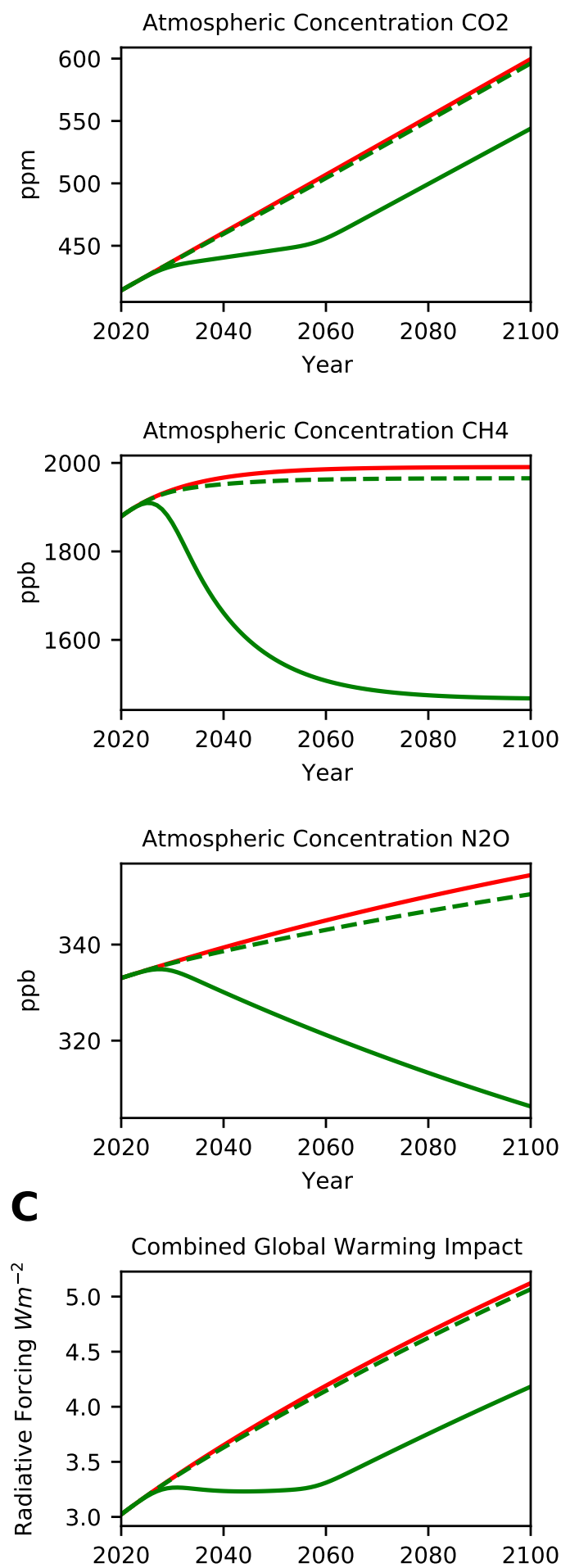

Figure 2-S26. Phaseout of Pig Meat.

(A) Projected annual emissions of $\mathrm{CO}_{2}, \mathrm{CH}_{4}$ and $\mathrm{N}_{2} \mathrm{O}$ for each scenarios. (B) Projected atmospheric concentrations of $\mathrm{CO}_{2}, \mathrm{CH}_{4}$ and $\mathrm{N}_{2} \mathrm{O}$ under each emission scenario. (C)

Radiative Forcing (RF) inferred from atmospheric concentrations in (B) by formula of (Myhre et al., 1998; Ramaswamy et al., 2001) as modified in MAGICC6 (Meinshausen et al., 2011). Only differences between PHASE-POD default assumptions (15yr phaseout, 30yr carbon recovery, 100\% carbon recovery, BAU non-agriculture emissions, FAO crop replacement, and FAO animal ag emissions) are given. 
bioRxiv preprint doi: https://doi.org/10.1101/2021.04.15.440019; this version posted October 12, 2021. The copyright holder for this preprint (which was not certified by peer review) is the author/funder, who has granted bioRxiv a license to display the preprint in perpetuity. It is made available under aCC-BY 4.0 International license.

\section{A}

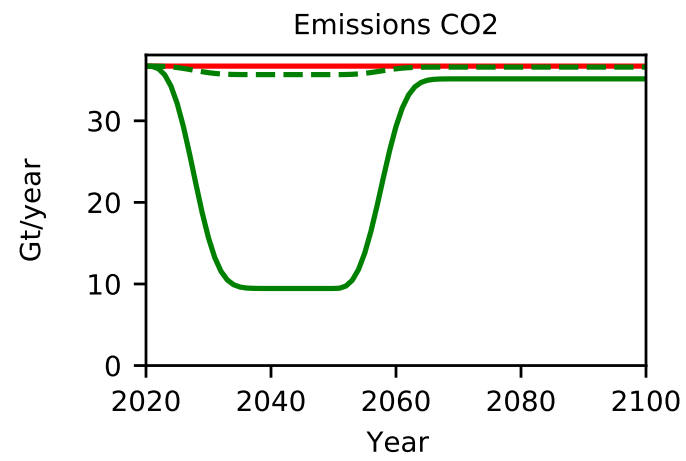

Emissions $\mathrm{CH} 4$

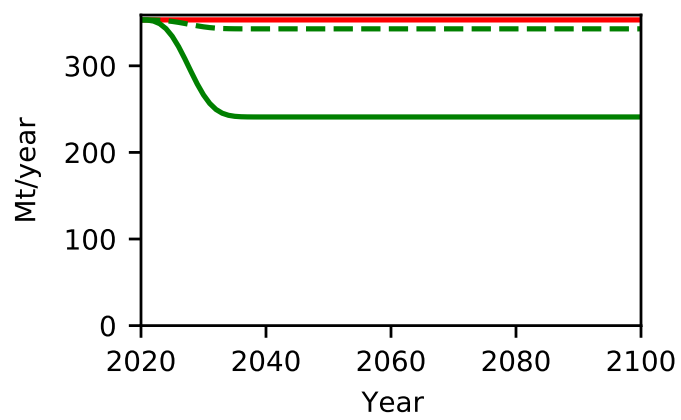

Emissions N2O

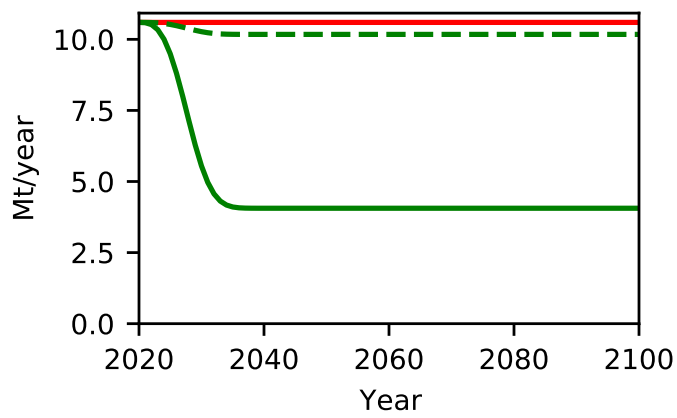

\section{B}
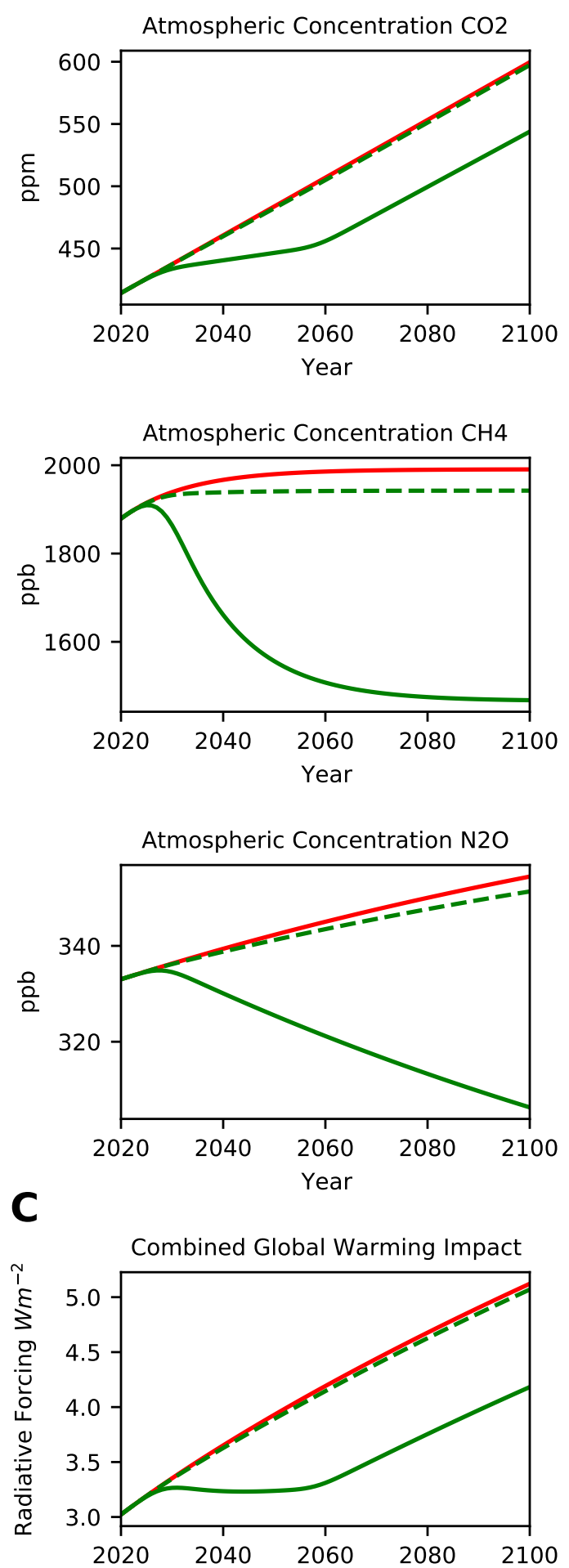

Figure 2-S27. Phaseout of Buffalo Milk.

(A) Projected annual emissions of $\mathrm{CO}_{2}, \mathrm{CH}_{4}$ and $\mathrm{N}_{2} \mathrm{O}$ for each scenarios. (B) Projected atmospheric concentrations of $\mathrm{CO}_{2}, \mathrm{CH}_{4}$ and $\mathrm{N}_{2} \mathrm{O}$ under each emission scenario. (C)

Radiative Forcing (RF) inferred from atmospheric concentrations in (B) by formula of (Myhre et al., 1998; Ramaswamy et al., 2001) as modified in MAGICC6 (Meinshausen et al., 2011). Only differences between PHASE-POD default assumptions (15yr phaseout, 30yr carbon recovery, 100\% carbon recovery, BAU non-agriculture emissions, FAO crop replacement, and FAO animal ag emissions) are given. 
bioRxiv preprint doi: https://doi.org/10.1101/2021.04.15.440019; this version posted October 12, 2021. The copyright holder for this preprint (which was not certified by peer review) is the author/funder, who has granted bioRxiv a license to display the preprint in perpetuity. It is made available under aCC-BY 4.0 International license.

\section{A}
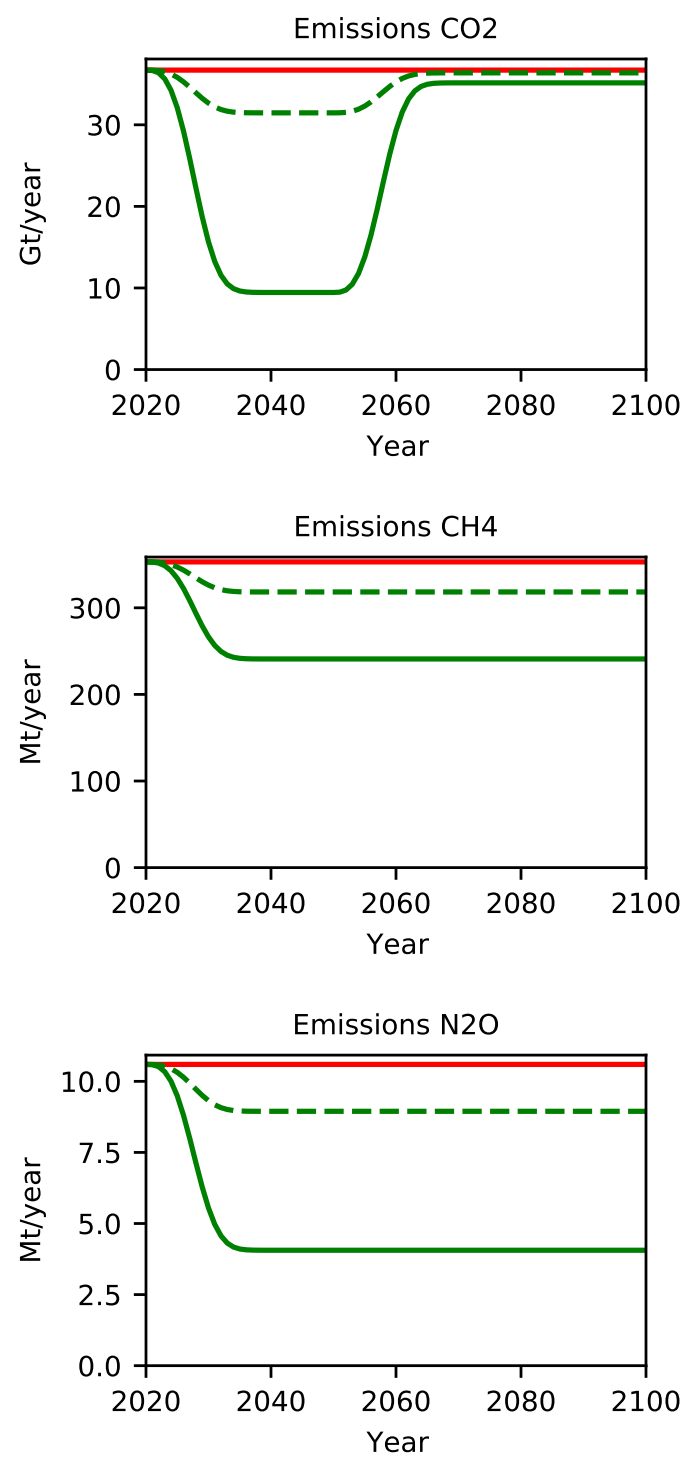

Business as Usual
- Phaseout cow milk
PHASE-POD (Default)
B
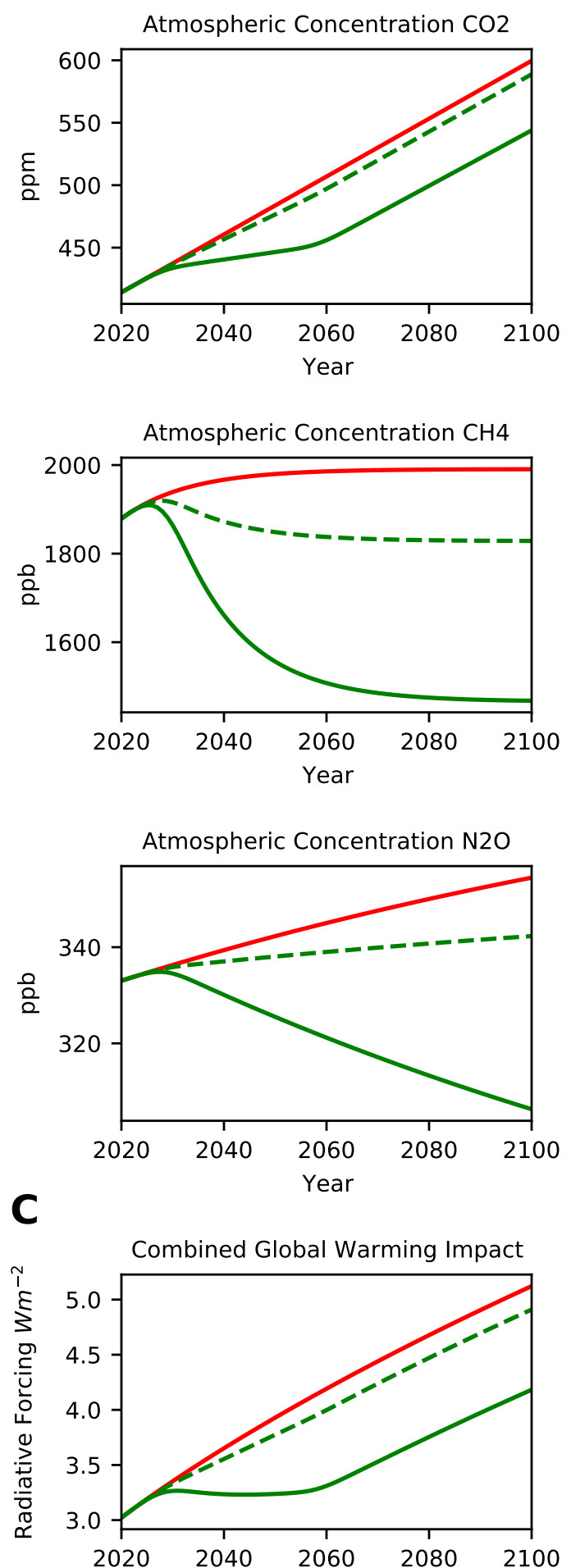

Figure 2-S28. Phaseout of Cow Milk.

(A) Projected annual emissions of $\mathrm{CO}_{2}, \mathrm{CH}_{4}$ and $\mathrm{N}_{2} \mathrm{O}$ for each scenarios. (B) Projected atmospheric concentrations of $\mathrm{CO}_{2}, \mathrm{CH}_{4}$ and $\mathrm{N}_{2} \mathrm{O}$ under each emission scenario. (C)

Radiative Forcing (RF) inferred from atmospheric concentrations in (B) by formula of (Myhre et al., 1998; Ramaswamy et al., 2001) as modified in MAGICC6 (Meinshausen et al., 2011). Only differences between PHASE-POD default assumptions (15yr phaseout, 30yr carbon recovery, 100\% carbon recovery, BAU non-agriculture emissions, FAO crop replacement, and FAO animal ag emissions) are given. 
bioRxiv preprint doi: https://doi.org/10.1101/2021.04.15.440019; this version posted October 12, 2021. The copyright holder for this preprint (which was not certified by peer review) is the author/funder, who has granted bioRxiv a license to display the preprint in perpetuity. It is made available under aCC-BY 4.0 International license.

\section{A}
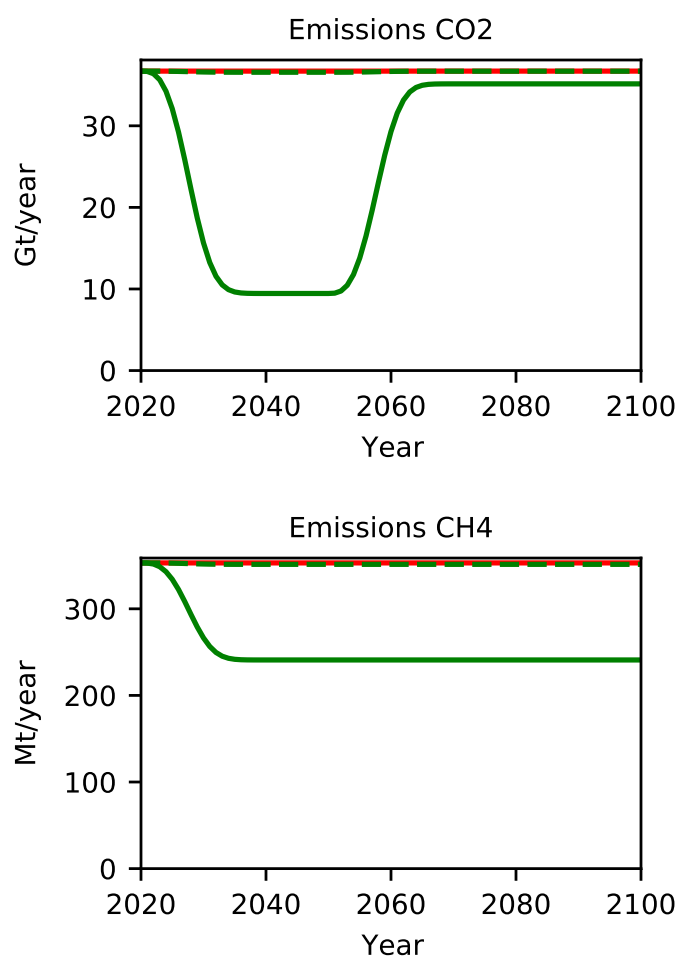

Emissions N2O

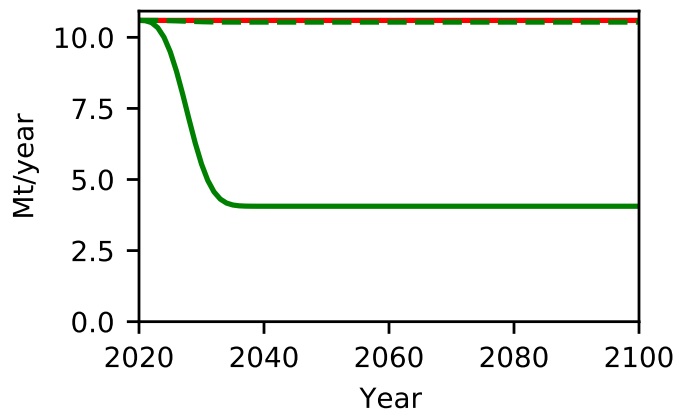

B
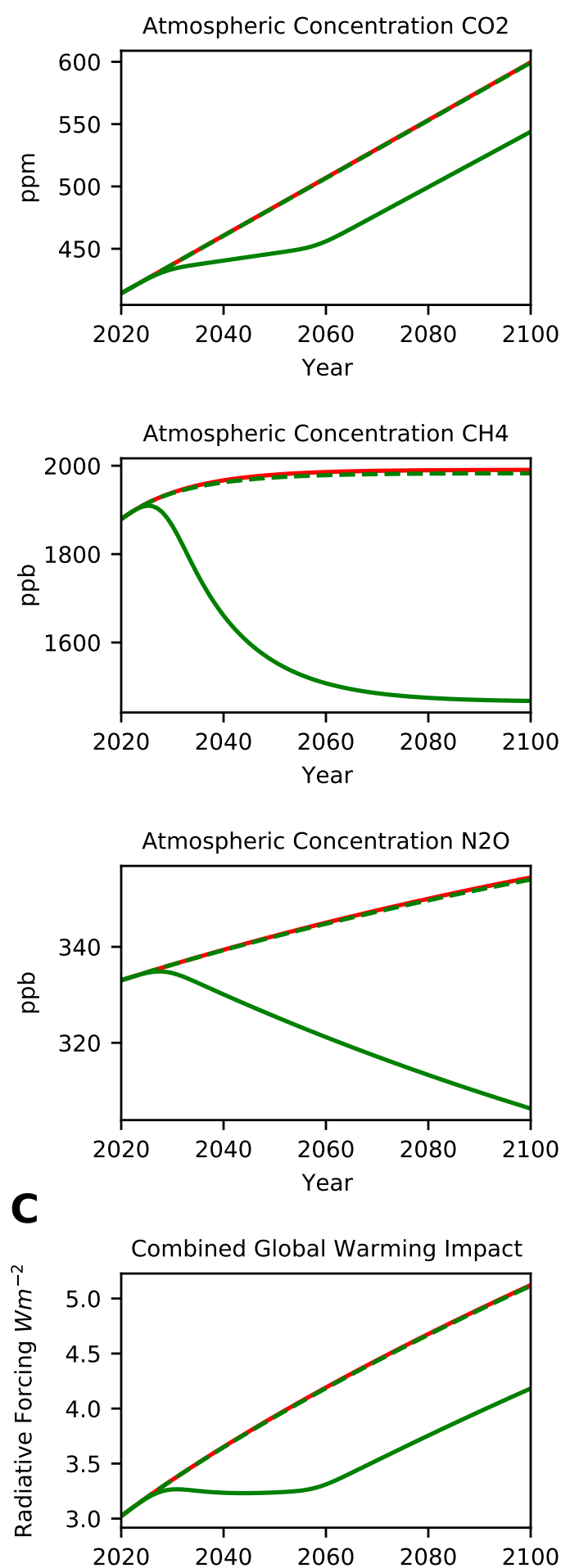

Figure 2-S29. Phaseout of Goat Milk.

(A) Projected annual emissions of $\mathrm{CO}_{2}, \mathrm{CH}_{4}$ and $\mathrm{N}_{2} \mathrm{O}$ for each scenarios. (B) Projected atmospheric concentrations of $\mathrm{CO}_{2}, \mathrm{CH}_{4}$ and $\mathrm{N}_{2} \mathrm{O}$ under each emission scenario. (C)

Radiative Forcing (RF) inferred from atmospheric concentrations in (B) by formula of (Myhre et al., 1998; Ramaswamy et al., 2001) as modified in MAGICC6 (Meinshausen et al., 2011). Only differences between PHASE-POD default assumptions (15yr phaseout, 30yr carbon recovery, 100\% carbon recovery, BAU non-agriculture emissions, FAO crop replacement, and FAO animal ag emissions) are given. 
bioRxiv preprint doi: https://doi.org/10.1101/2021.04.15.440019; this version posted October 12, 2021. The copyright holder for this preprint (which was not certified by peer review) is the author/funder, who has granted bioRxiv a license to display the preprint in perpetuity. It is made available under aCC-BY 4.0 International license.

\section{A}
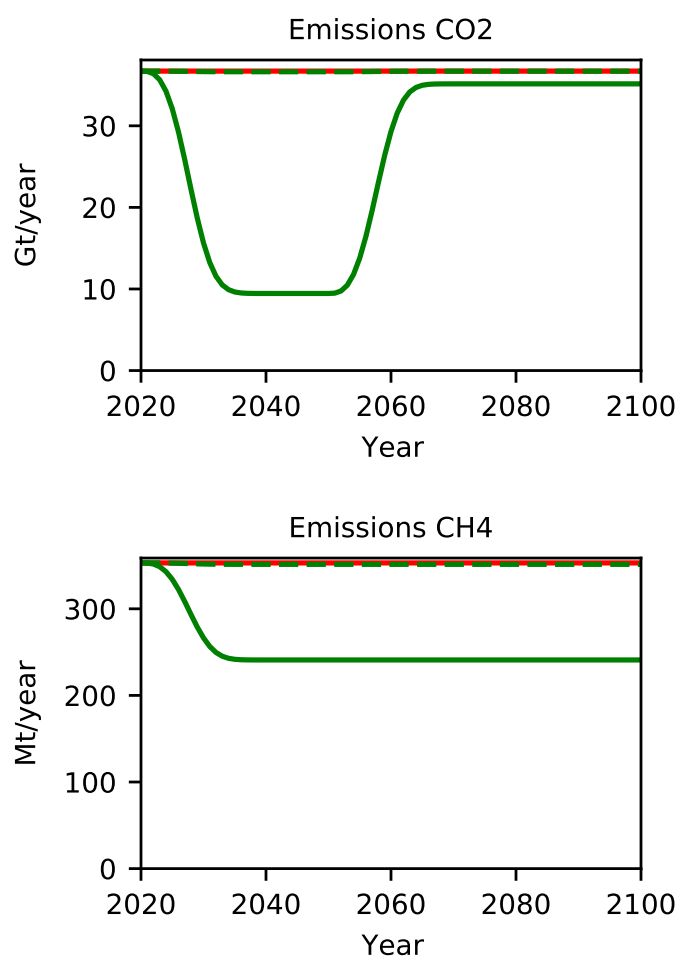

Emissions N2O

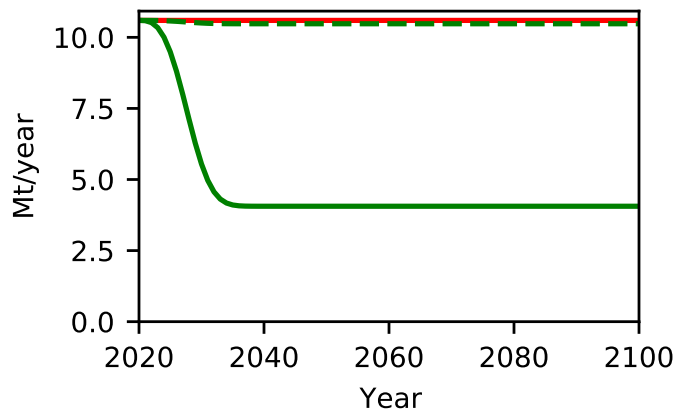

Business as Usual

- Phaseout sheep milk

PHASE-POD (Default)
B
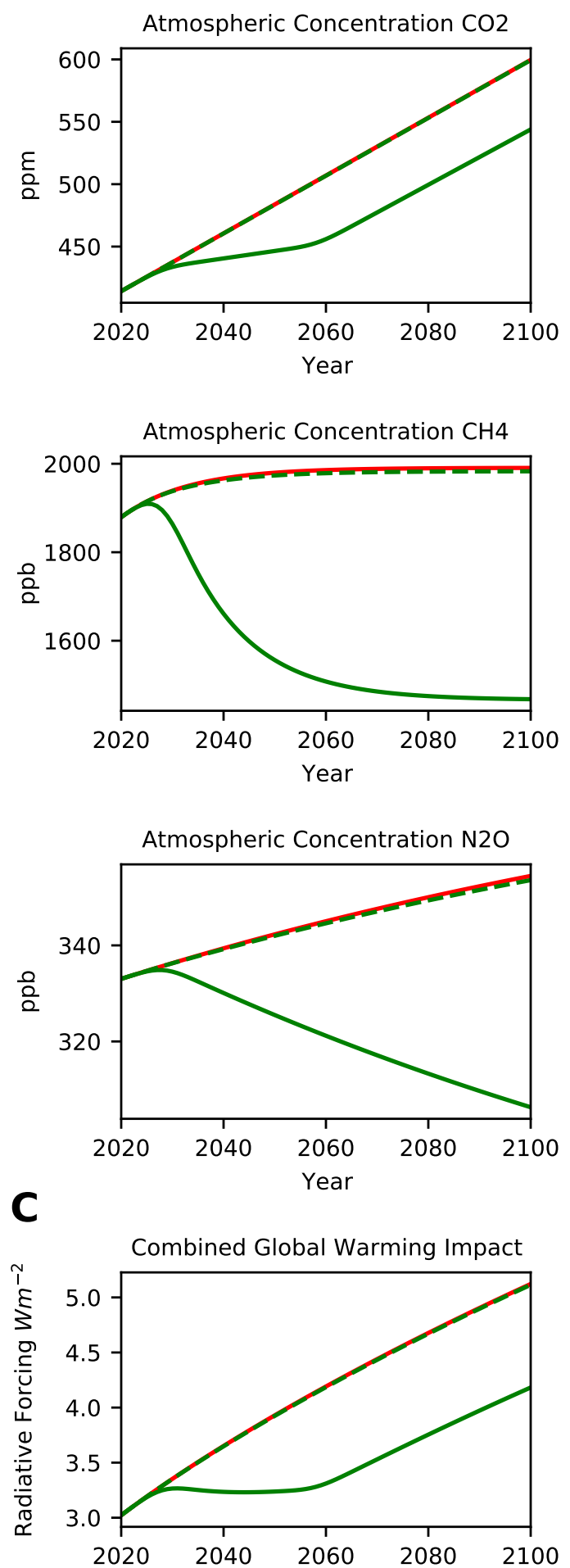

Figure 2-S30. Phaseout of Sheep Milk.

(A) Projected annual emissions of $\mathrm{CO}_{2}, \mathrm{CH}_{4}$ and $\mathrm{N}_{2} \mathrm{O}$ for each scenarios. (B) Projected atmospheric concentrations of $\mathrm{CO}_{2}, \mathrm{CH}_{4}$ and $\mathrm{N}_{2} \mathrm{O}$ under each emission scenario. (C)

Radiative Forcing (RF) inferred from atmospheric concentrations in (B) by formula of (Myhre et al., 1998; Ramaswamy et al., 2001) as modified in MAGICC6 (Meinshausen et al., 2011). Only differences between PHASE-POD default assumptions (15yr phaseout, 30yr carbon recovery, 100\% carbon recovery, BAU non-agriculture emissions, FAO crop replacement, and FAO animal ag emissions) are given. 
bioRxiv preprint doi: https://doi.org/10.1101/2021.04.15.440019; this version posted October 12, 2021. The copyright holder for this preprint (which was not certified by peer review) is the author/funder, who has granted bioRxiv a license to display the preprint in perpetuity. It is made available under aCC-BY 4.0 International license.

\section{A}
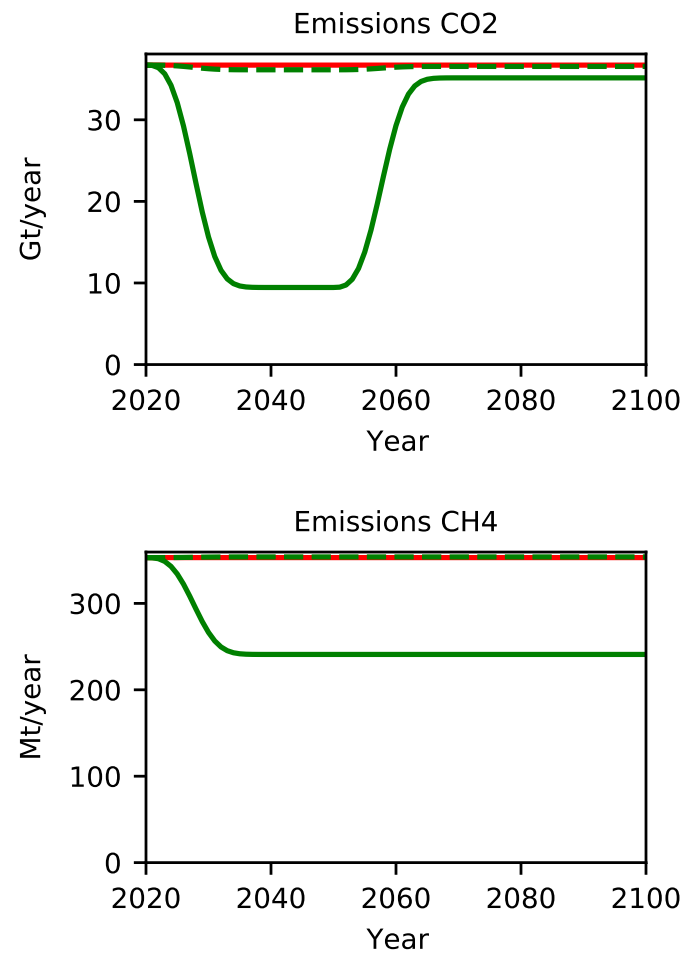

Emissions N2O

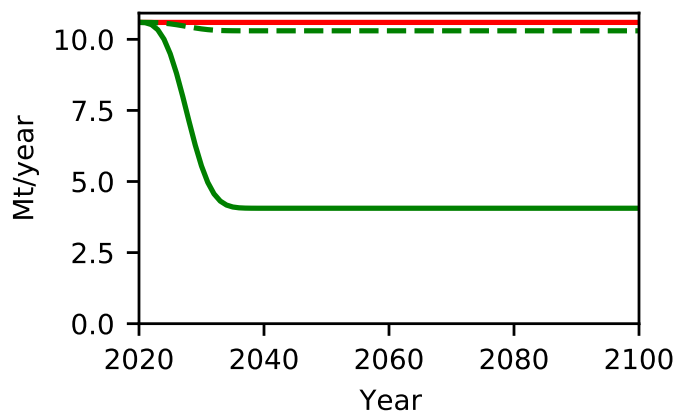

Business as Usual
- Phaseout eggs
PHASE-POD (Default)
B
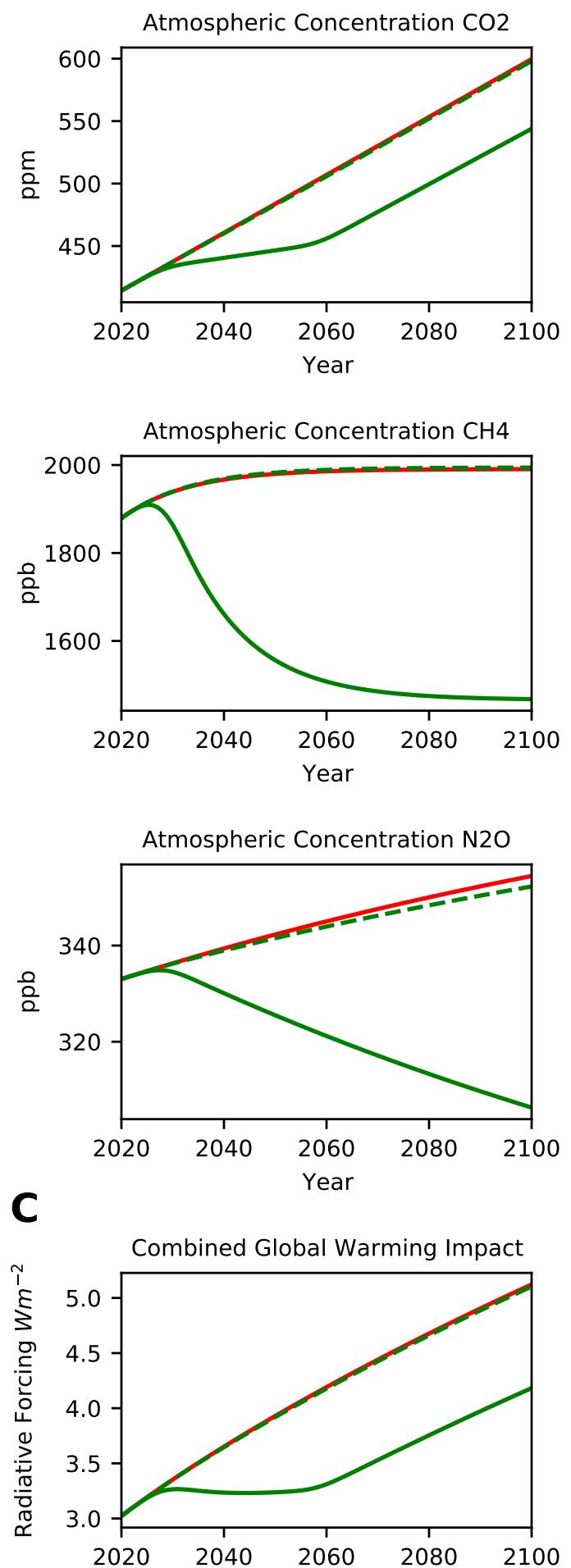

Figure 2-S31. Phaseout of Eggs.

(A) Projected annual emissions of $\mathrm{CO}_{2}, \mathrm{CH}_{4}$ and $\mathrm{N}_{2} \mathrm{O}$ for each scenarios. (B) Projected atmospheric concentrations of $\mathrm{CO}_{2}, \mathrm{CH}_{4}$ and $\mathrm{N}_{2} \mathrm{O}$ under each emission scenario. (C)

Radiative Forcing (RF) inferred from atmospheric concentrations in (B) by formula of (Myhre et al., 1998; Ramaswamy et al., 2001) as modified in MAGICC6 (Meinshausen et al., 2011). Only differences between PHASE-POD default assumptions (15yr phaseout, 30yr carbon recovery, 100\% carbon recovery, BAU non-agriculture emissions, FAO crop replacement, and FAO animal ag emissions) are given. 


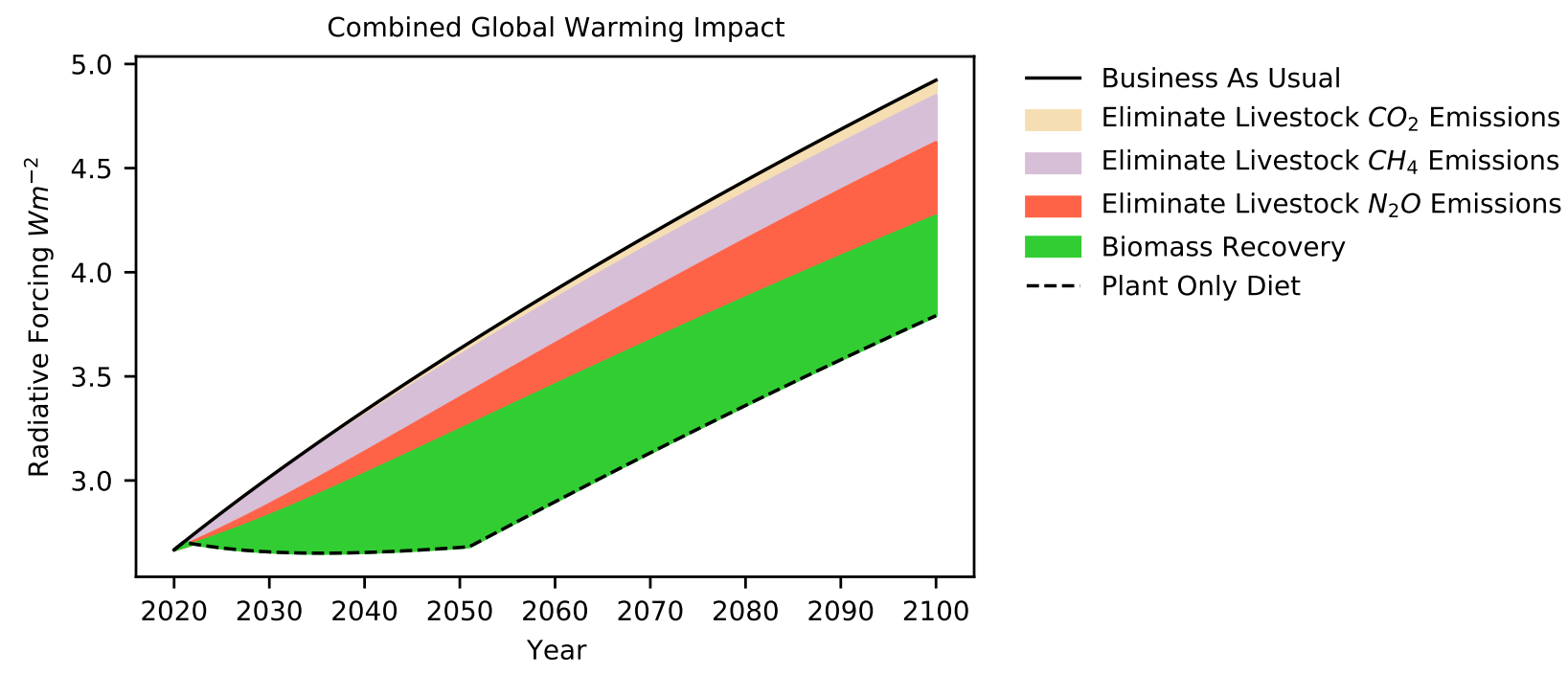

Figure 3-S1. Immediate elimination of animal agriculture reduces global warming impact of atmosphere.

Effect of eliminating emissions linked to animal agriculture and of biomass recovery on land currently used in animal agriculture on Radiative Forcing (RF), a measure of the instantaneous warming potential of the atmosphere. RF values computed from atmospheric concentrations in by formula of (Myhre et al., 1998; Ramaswamy et al., 2001) as modified in MAGICC6 (Meinshausen et al., 2011) with adjustment for gasses other than $\mathrm{CO}_{2}, \mathrm{CH}_{4}$ and $\mathrm{N}_{2} \mathrm{O}$ as described in text. 


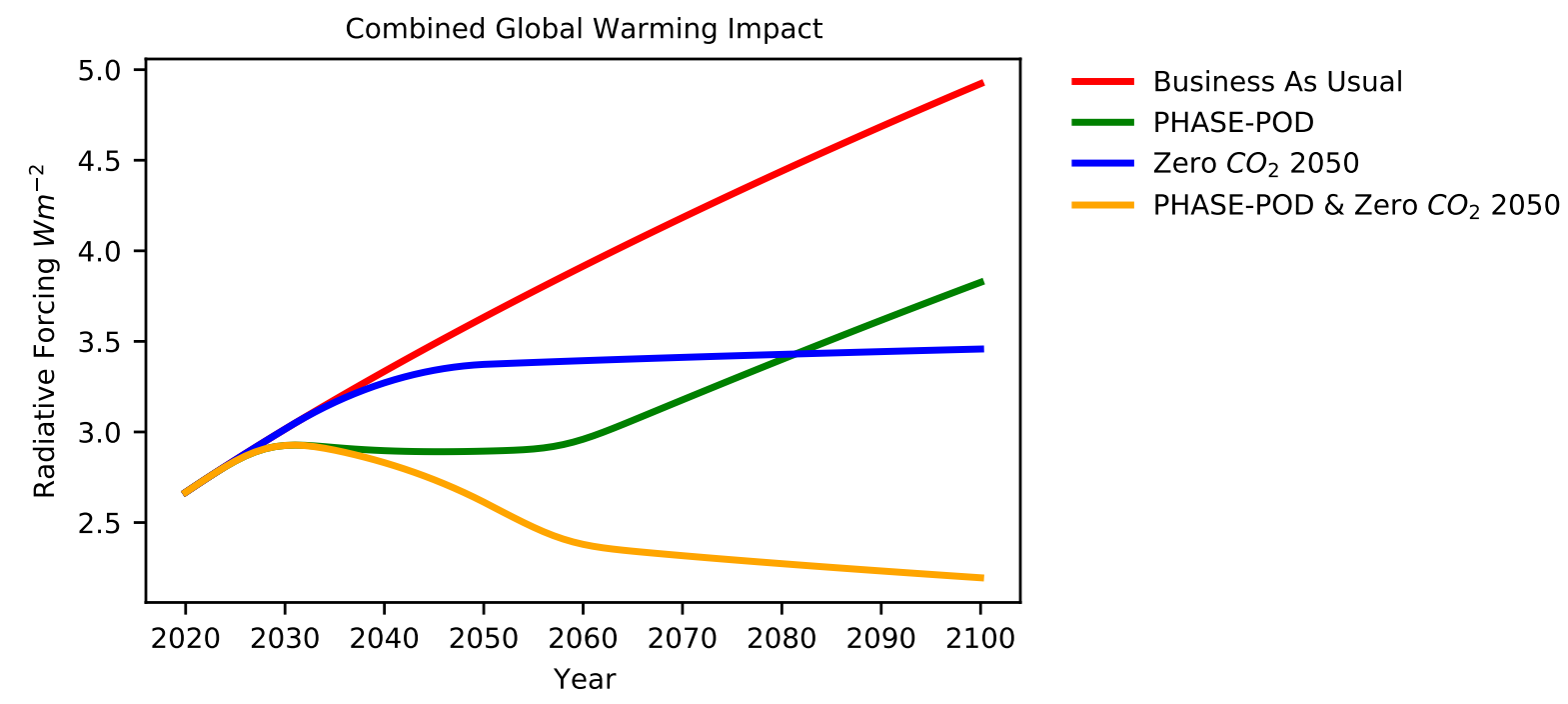

Figure 3-S2. Similar effects of phaseout of animal ag and drawdown of $\mathrm{CO}_{2}$ emissions

Comparison of effects of PHASE-POD (a 15 year phaseout of animal agriculture) and a linear drawdown of all anthropogenic $\mathrm{CO}_{2}$ emissions between 2030 and 2050, and the two combined, on Radiative Forcing (RF), a measure of the instantaneous warming potential of the atmosphere. RF values computed from atmospheric concentrations in by formula of (Myhre et al., 1998; Ramaswamy et al., 2001) as modified in MAGICC6 (Meinshausen et al., 2011) with adjustment for gasses other than $\mathrm{CO}_{2}, \mathrm{CH}_{4}$ and $\mathrm{N}_{2} \mathrm{O}$ as described in text. 


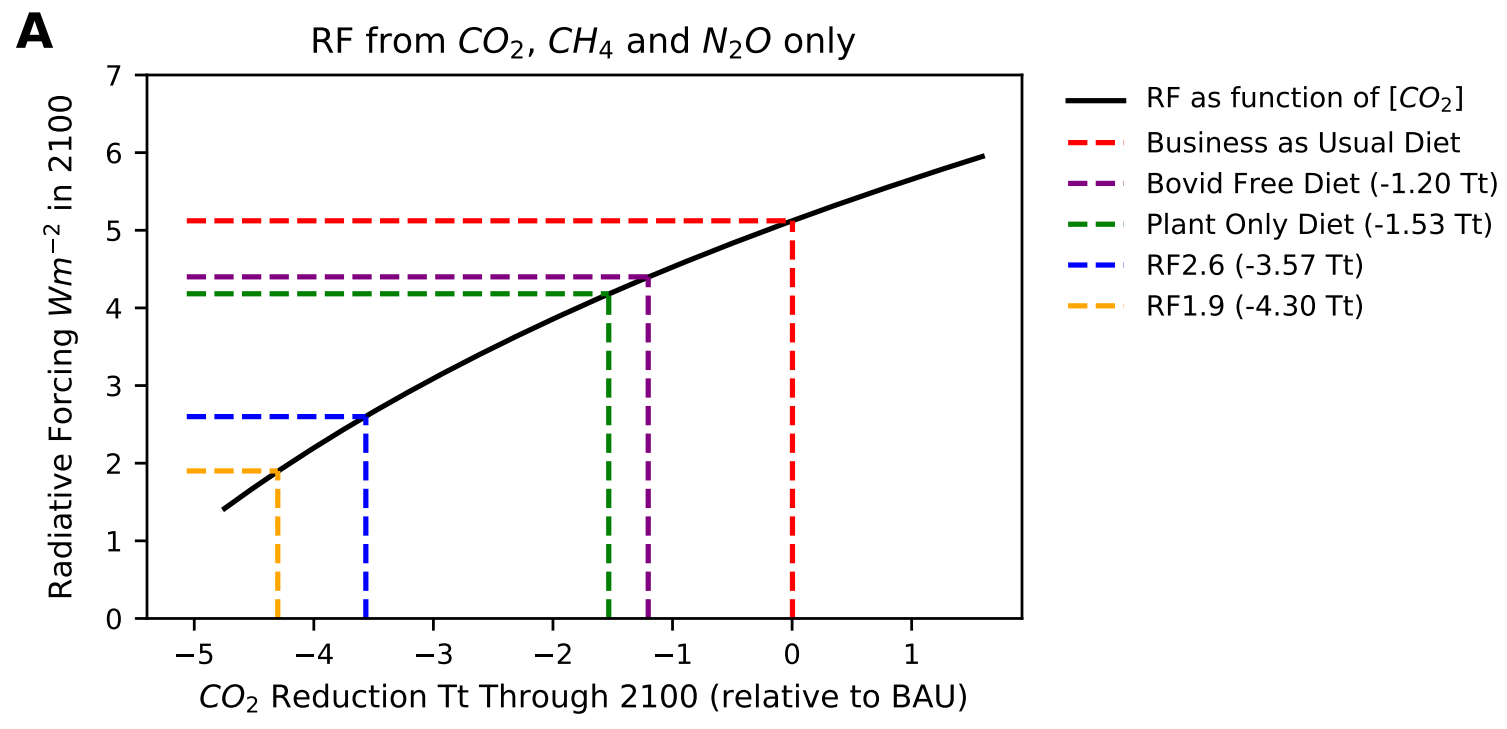

\section{B}

RF w/adjustment for other gases

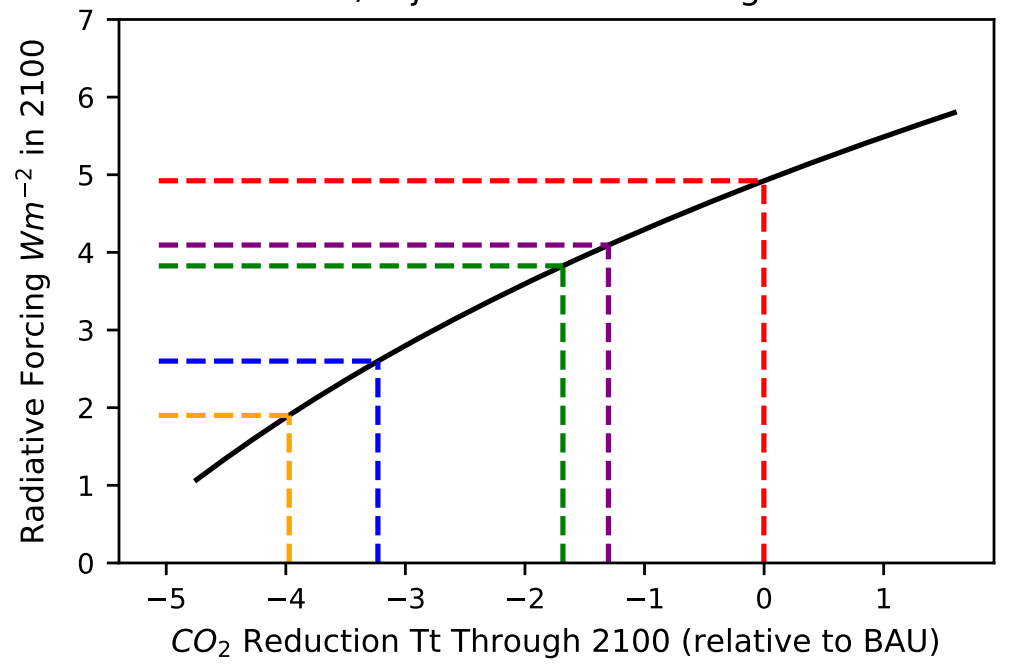

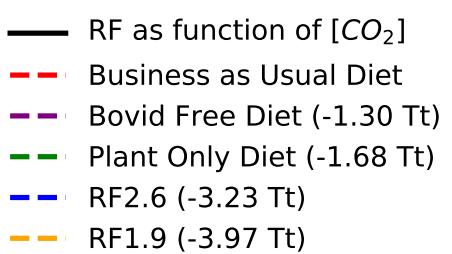

Figure 4-S1. Full carbon opportunity cost of animal agriculture.

We define the Emission and Land Carbon Opportunity Cost of animal agriculture as the total $\mathrm{CO}_{2}$ reduction necessary to lower the RF in 2100 from the level estimated for a business as usual (BAU) diet to the level estimated for a plant only diet (POD). For these calculations we fix the $\mathrm{CH}_{4}$ and $\mathrm{N}_{2} \mathrm{O}$ levels in the RF calculation at those estimated for the BAU diet in 2100 and adjust $\mathrm{CO}_{2}$ levels to reach the target RF. We also calculate ELCOC for just bovid sourced foods and determine the emission reductions necessary to reach RF's of 2.6 and 1.9, often cited as targets for limiting warming to $2.0^{\circ} \mathrm{C}$ and $1.5^{\circ} \mathrm{C}$ respectively. (A) Shows the results for RF directly calculated from $\mathrm{CO}_{2}, \mathrm{CH}_{4}$ and $\mathrm{N}_{2} \mathrm{O}$, while (B) shows an RF adjusted for other gases using multivariate linear regression on MAGICC6 output downloaded from the SSP database. 
bioRxiv preprint doi: https://doi.org/10.1101/2021.04.15.440019; this version posted October 12, 2021. The copyright holder for this preprint (which was not certified by peer review) is the author/funder, who has granted bioRxiv a license to display the preprint in perpetuity. It is made available under aCC-BY 4.0 International license.

A
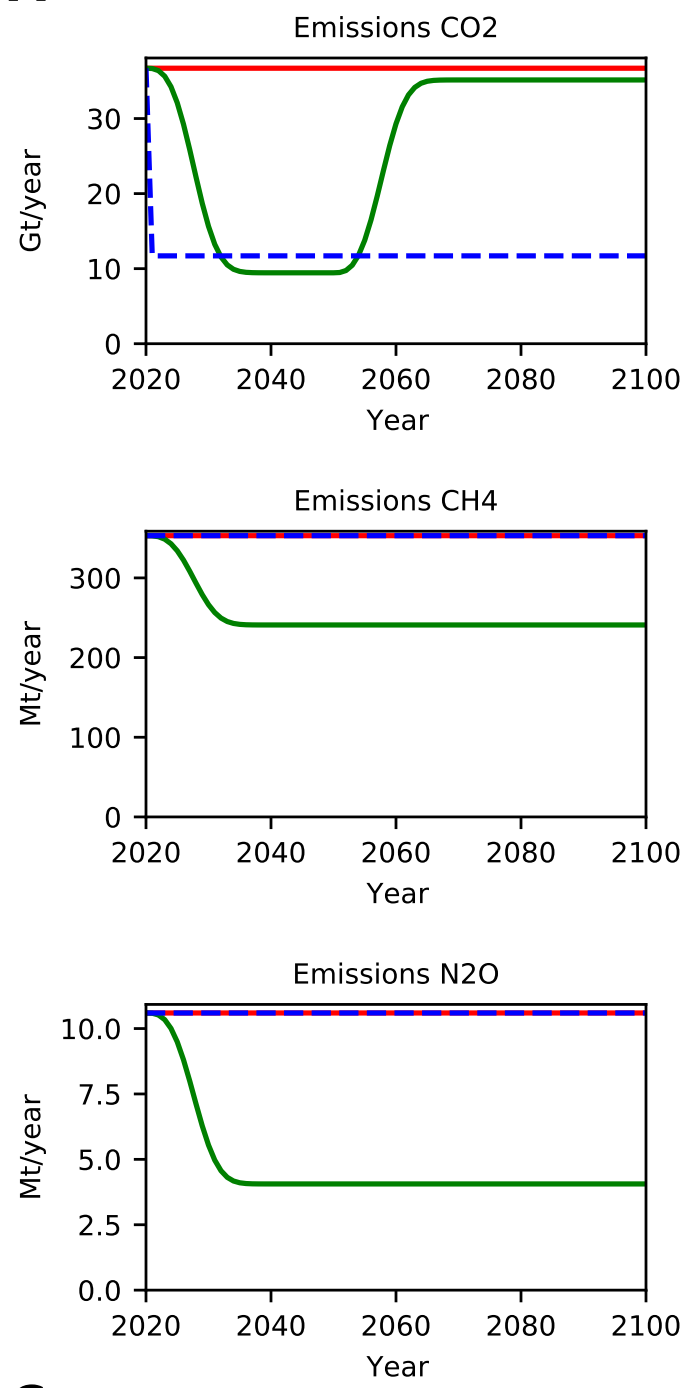

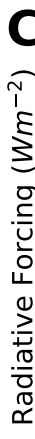

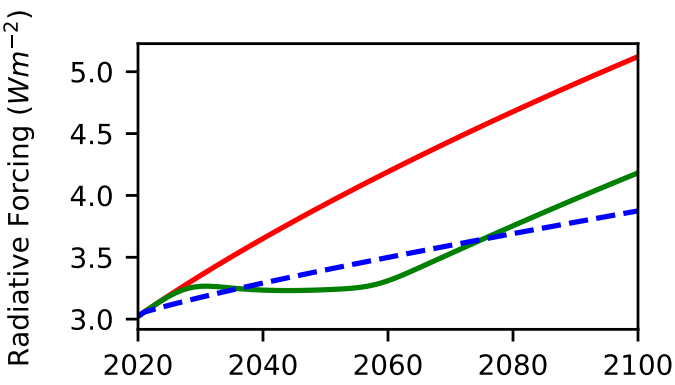

B
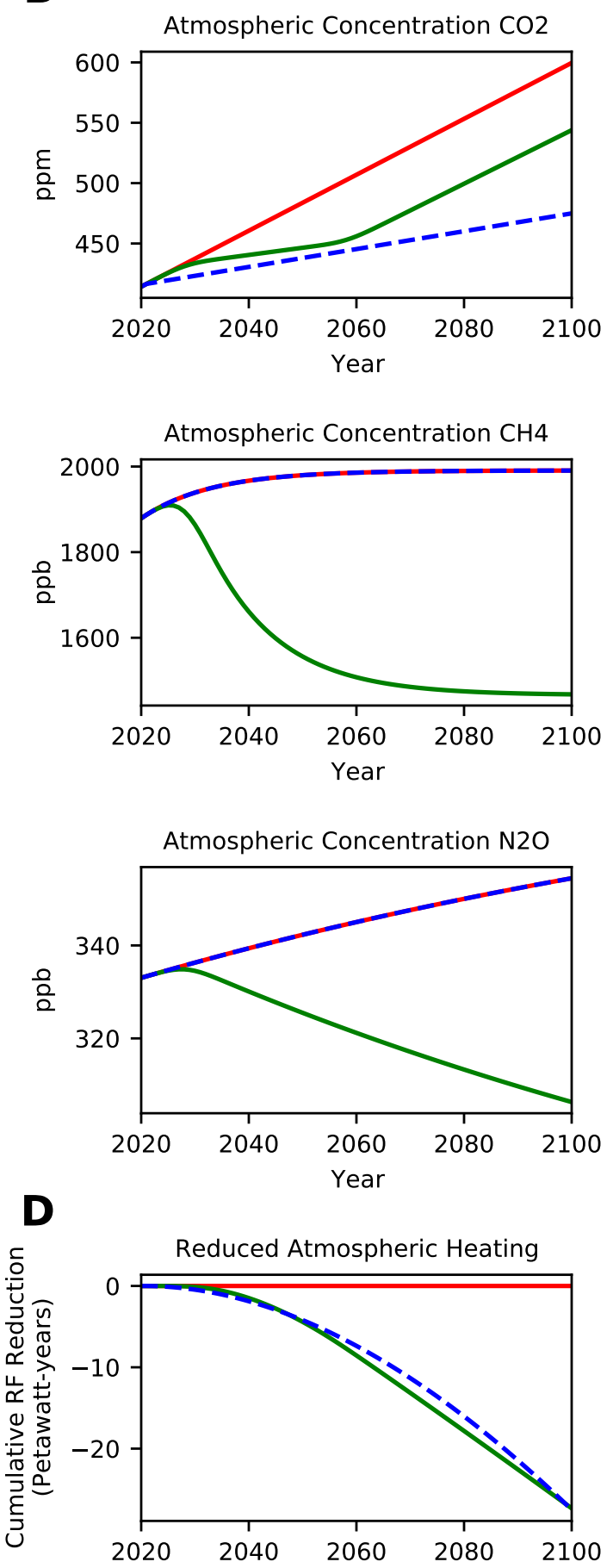

Business as Usual

15 Year Phaseout of Animal Ag

- 25Gt Reduction in $\mathrm{CO} 2$

Figure 5-S1. $\mathrm{ACO}_{2}$ eq Calibration for PHASE-POD in 2100.

(A) Projected annual emissions of $\mathrm{CO}_{2}, \mathrm{CH}_{4}$ and $\mathrm{N}_{2} \mathrm{O}$ for shown scenarios. (B) Projected atmospheric concentrations of $\mathrm{CO}_{2}, \mathrm{CH}_{4}$ and $\mathrm{N}_{2} \mathrm{O}$ under each emission scenario. (C) Radiation Forcing. (D) Cumulative difference between scenario and BAU of Radiative Forcing. 
bioRxiv preprint doi: https://doi.org/10.1101/2021.04.15.440019; this version posted October 12, 2021. The copyright holder for this preprint (which was not certified by peer review) is the author/funder, who has granted bioRxiv a license to display the preprint in perpetuity. It is made available under aCC-BY 4.0 International license.

A
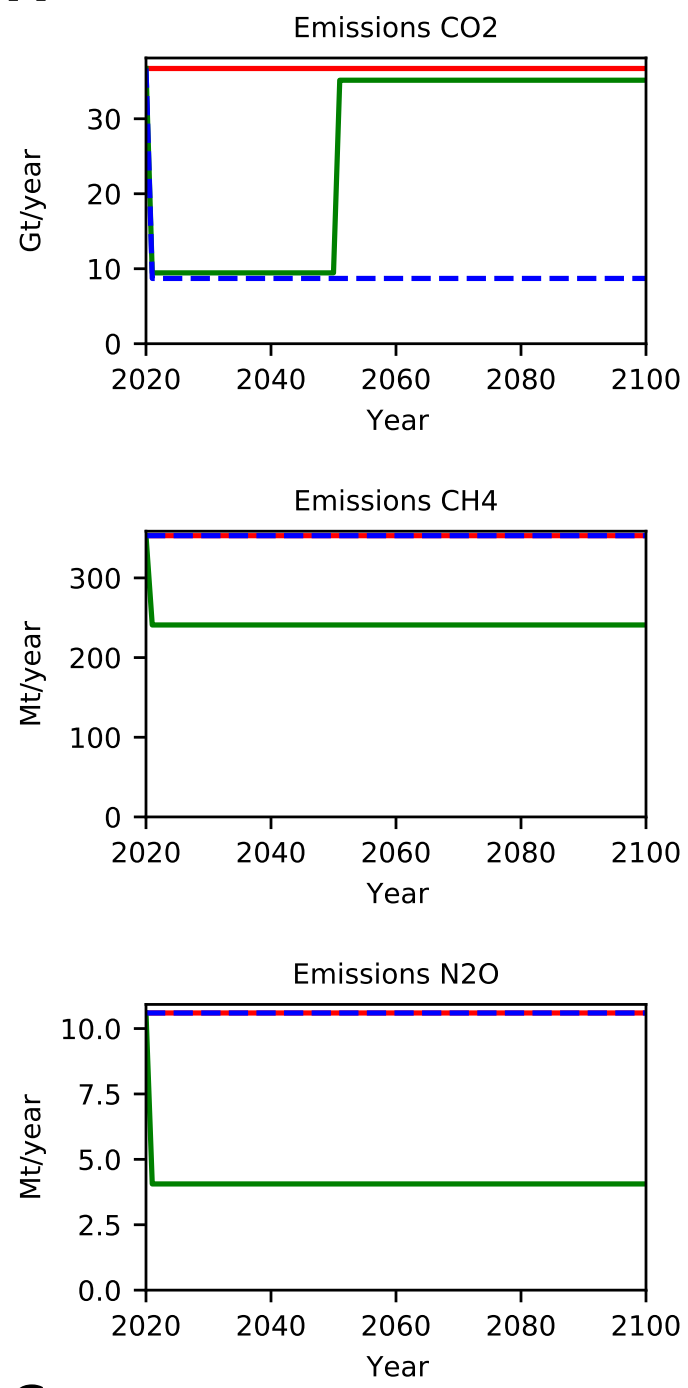

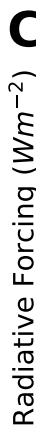

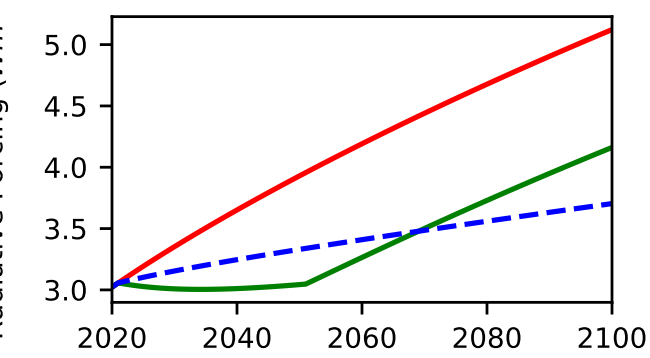

B
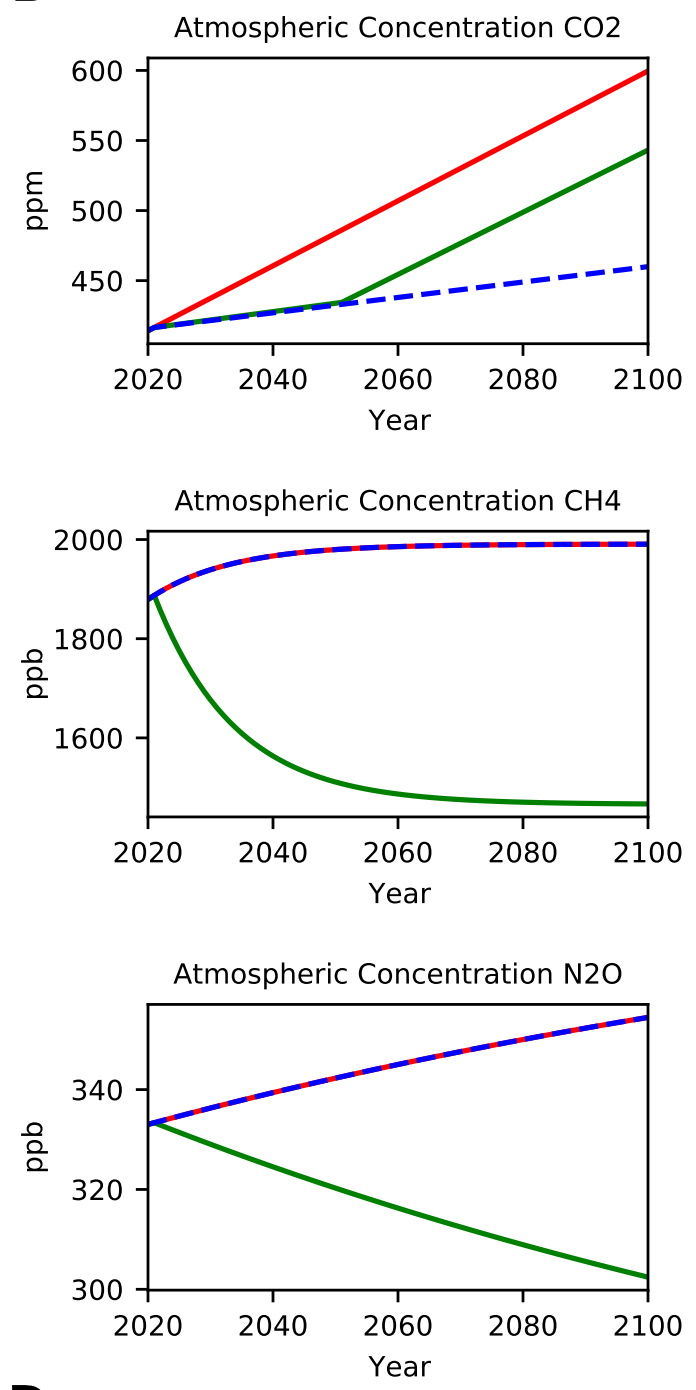

D

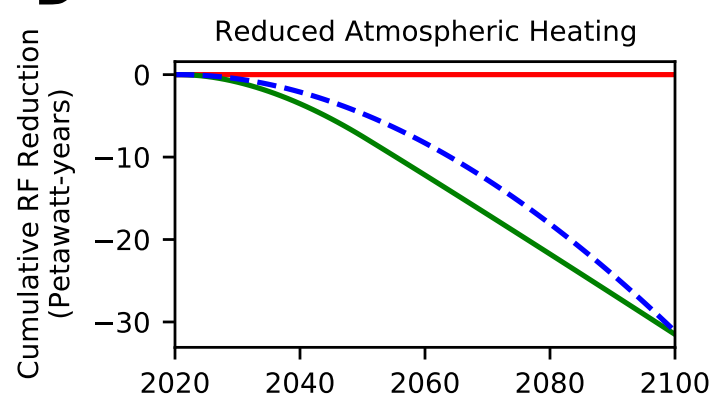

Figure 5-S2. $\mathrm{ACO}_{2}$ eq Calibration for IMM-POD in 2100.

(A) Projected annual emissions of $\mathrm{CO}_{2}, \mathrm{CH}_{4}$ and $\mathrm{N}_{2} \mathrm{O}$ for shown scenarios. (B) Projected atmospheric concentrations of $\mathrm{CO}_{2}, \mathrm{CH}_{4}$ and $\mathrm{N}_{2} \mathrm{O}$ under each emission scenario. (C) Cumulative difference between scenario and $\mathrm{BAU}$ of Radiative Forcing. 
bioRxiv preprint doi: https://doi.org/10.1101/2021.04.15.440019; this version posted October 12, 2021. The copyright holder for this preprint (which was not certified by peer review) is the author/funder, who has granted bioRxiv a license to display the preprint in perpetuity. It is made available under aCC-BY 4.0 International license.

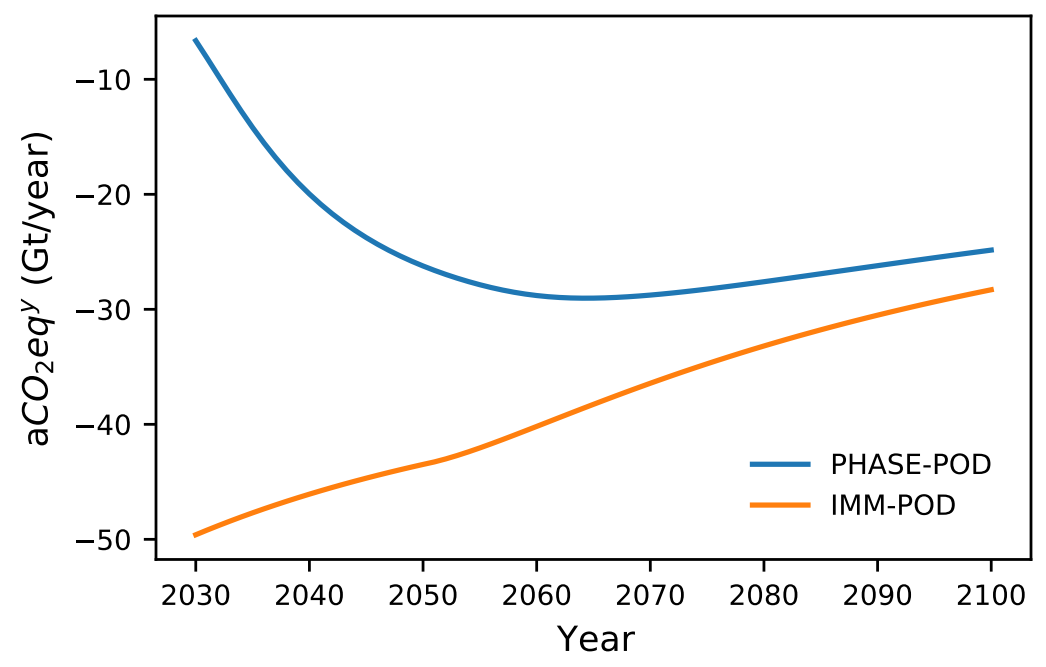

Figure 5-S3. Emissions reduction equivalents of ending animal agriculture

The equivalent $\mathrm{CO}_{2}$ emission reductions associated with different interventions in animal agriculture, $\mathrm{aCO}_{2}$ eq, vary with the time window over which cumulative warming impact is evaluated. These plots show, for immediate elimination of animal agriculture (IMM-POD) and a 15-year phaseout (PHASE-POD) how $\mathrm{aCO}_{2} \mathrm{eq}^{y}$ which is the $\mathrm{aCO}_{2}$ eq from 2021 to year $\mathrm{y}$, varies with $\mathrm{y}$. Because all of the changes in IMM-POD are implemented immediately, its effect is biggest as it is implemented and declines over longer time horizons (the decline in the first 30 years, when biomass recovery is occurring at a constant high right, is due to the slowing of annual decreases in atmospheric $\mathrm{CH}_{4}$ and $\mathrm{N}_{2} \mathrm{O}$ levels as they asymptotically approach new equilibria). In contrast, PHASE-POD builds slowly, reaching a maximum around 2060 when biomass recovery peaks. 


\section{A}

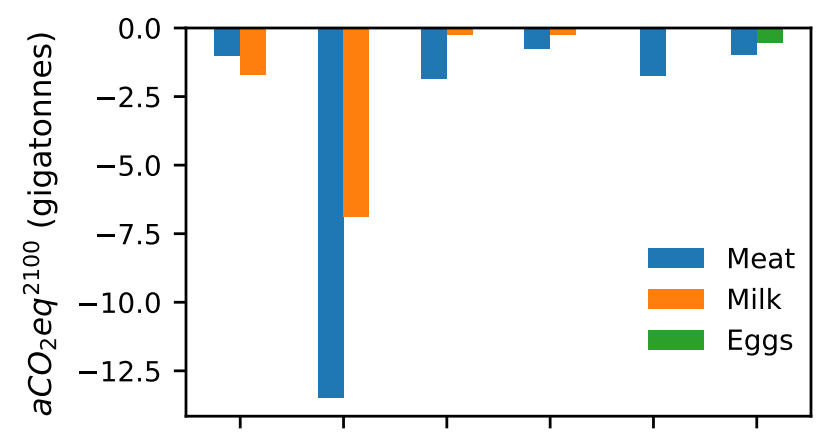

B

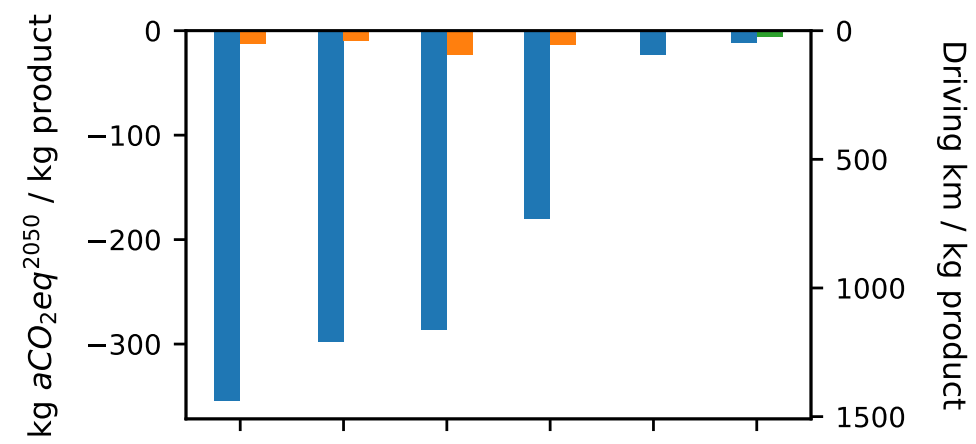

C

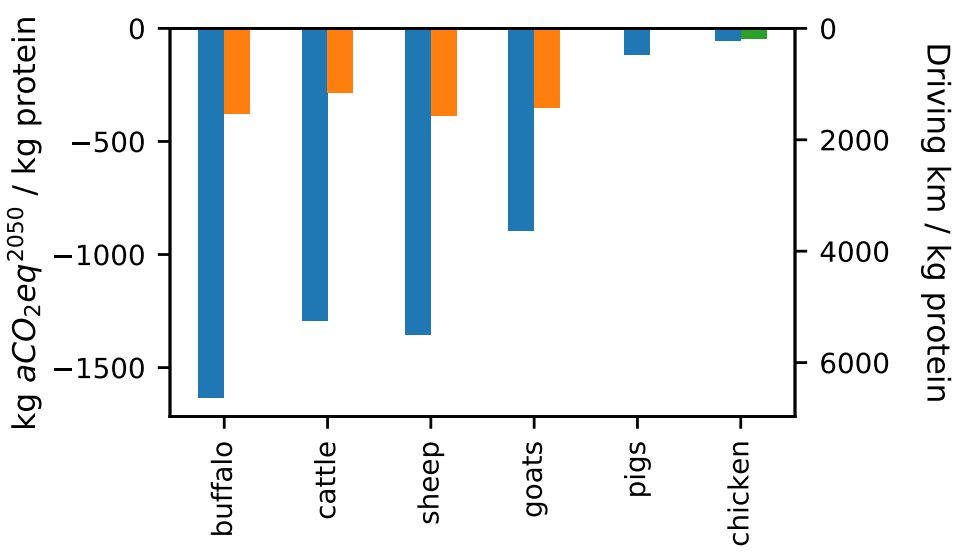

Figure 6-S1. Emission equivalents of livestock products through 2100.

We calculated the (A) total annualized $\mathrm{CO}_{2}$ equivalents through $2100, \mathrm{aCO}_{2} e q^{2100}$, for all tracked animal products, and the $\mathrm{aCO}_{2} \mathrm{eq}^{2100}$ per unit production (B) or per unit protein (C). For (B) and (C) we also convert the values to driving equivalents, assuming cars that get $10.6 \mathrm{~km}$ per liter of gas (the average of new cars in the United States). 
bioRxiv preprint doi: https://doi.org/10.1101/2021.04.15.440019; this version posted October 12, 2021. The copyright holder for this preprint (which was not certified by peer review) is the author/funder, who has granted bioRxiv a license to display the preprint in perpetuity. It is made available under aCC-BY 4.0 International license.

A

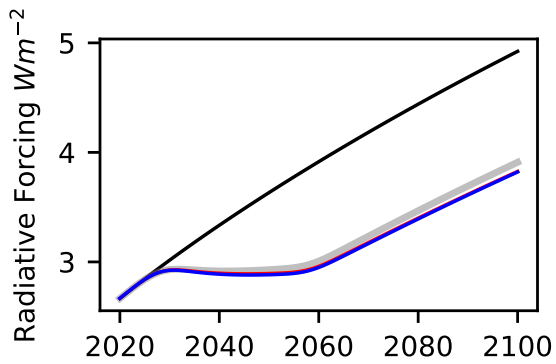

- Business As Usual

Xu et al. Replacement

FAOSTAT Crop Replacement

Soy Replacement

B

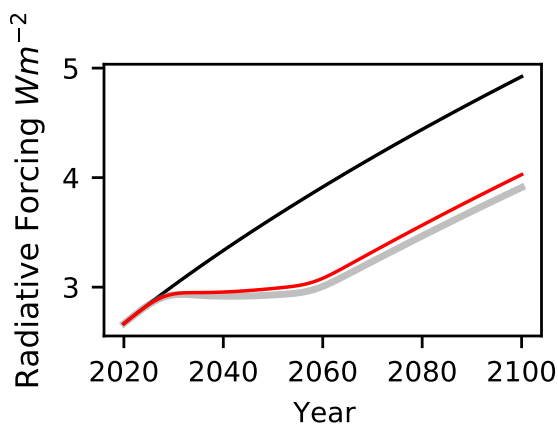

Business As Usual

GLEAM/FAOSTAT Livestock Emissions

$\mathrm{Xu}$ et al. Livestock Emissions

Figure 7-S1. Sensitivity of impact of phaseout of animal agriculture to model assumptions.

The grey line in each plot is PHASE-POD, the default scenario of 15 year phaseout, 30 year carbon recovery, livestock emissions from FAOSTAT, and a diverse plant replacement diet based on (Xu et al., 2021). (A) Effect of substituting the default plant based replacement diet from (Xu et al., 2021) with a diet based on all current human consumed crops using data from FAOSTAT, or a soy only replacment diet. (B) Effect of substituting default combined emissions of animal agriculture estimated via GLEAM and FAOSTAT with those from (Xu et al., 2021). 